Geology and

Water Resources of

Portage County

Wisconsin

GEOLOGICAL SURVEY WATER-SUPPLY PAPER 1796

Prepared in cooperation with the

University of Wisconsin Geological

and Natural History Survey

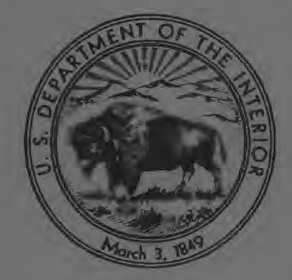




\section{Geology and}

\section{Water Resources of}

\section{Portage County \\ Wisconsin}

By C. L. R. HOLT, JR.

GEOLOGICAL SURVEY WATER-SUPPLY PAPER 1796

Prepared in cooperation with the

University of $W$ isconsin Geological

and Natural History Survey 


\section{UNITED STATES DEPARTMENT OF THE INTERIOR}

STEWART L. UDALL, Secretary

\section{GEOLOGICAL SURVEY}

Thomas B. Nolan, Director

Library of Congress catalog-card No. GS65-327 


\section{CONTENTS}

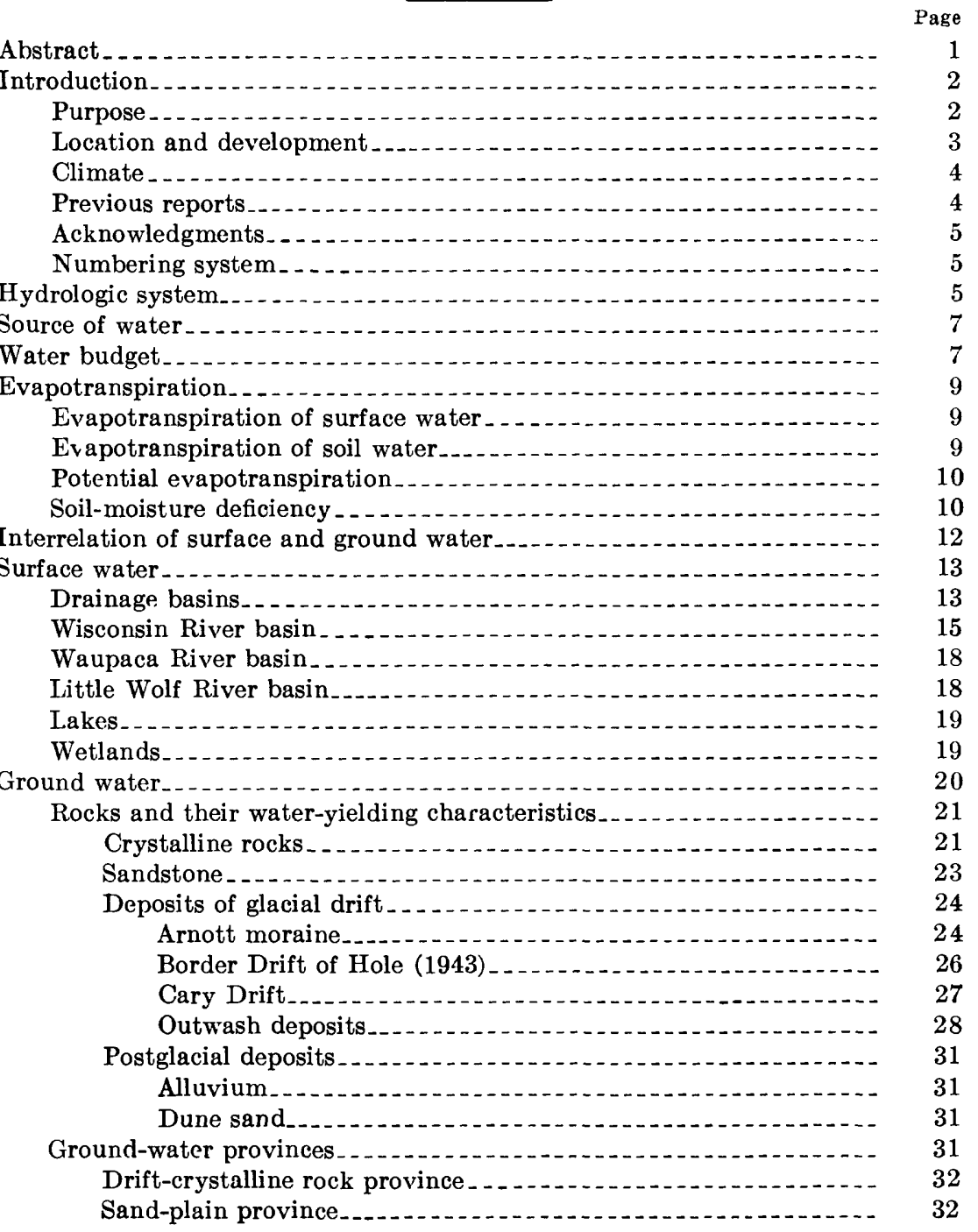


Ground water-Continued

Ground-water provinces-Continued

Drift province........... 33

Hydraulic properties of aquifers. 34

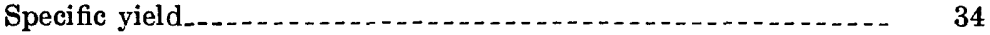

Pumping test determinations of aquifer characteristics._.

Effects of pumping on water levels.................... 37

Specific capacity of wells _. 39

Movement_..._. 39

Water-level fluctuations .

Recharge

Natural recharge....... 48

Induced recharge

Discharge

Ground-water runoff $\ldots \ldots$

Underflow .............. 53

Pumpage........... 54

Evapotranspiration

Quality of water... 54

Chemical character .

Hardness

Iron

Sodium...... 59

Temperature._._. 59

Pollution

Water use

Private industry

Public supply _... 63

Domestic and stock

Irrigation............ 63

Wildlife and recreation

Water-management problems and their possible solutions

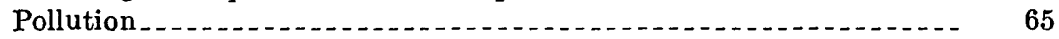

Inadequate water supply

Excessive declines in water level

Undesirable chemical quality

Conflict of interests... 67

Floods .

Recommendations for future studies

Conclusions..... 69

Selected references_._._.

Index..... 75

\section{ILLUSTRATIONS}

Plate 1. Map showing surface geology and sections showing subsurface geology of Portage County, Wis . . . . . . . . In pocket

2. Map of Portage County, Wis., showing configuration of water table, May 1954_..... In pocket 
Figure 1. Index map showing location of Portage County, Wis.... -

2. Sketch showing well-numbering system _..............

3. Sketch showing generalized water budget for Portage County, 1960

4. Graphs showing comparison of precipitation to estimated potential evapotranspiration. . . . . . . . . . . . . . . .

5. Map showing hydrologic divides between Waupaca, Wis. and Little Wolf Rivers drainage basins. .............

6. Graph showing duration curves of daily flow per square

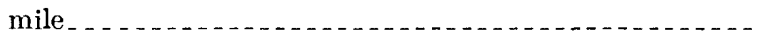

7. Map showing altitude of surface of crystalline rocks. .....

8. Map showing location of moraines... . . . . . . . . .

9. Map showing thickness of unconsolidated deposits. ......

10. Sample log of well Pt-21/9/22-265_...

11. Graph showing distance-drawdown relation for high-capacity wells tapping the sand and gravel aquifer.........

12-15. Graphs showing changes in water level in-

12. Well Pt-22/8/1-30, 1945-55

13. Wells Pt-22/7/35-35, Pt-23/7/34-34, and Pt-

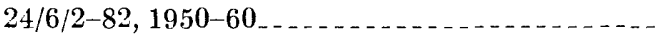

14. Wells Pt-24/8/2-40 and Pt-24/10/28-15, 1950-60_-

15. Well $\mathrm{Pt}-24 / 6 / 2-82$ and climatological data, 1952 _-

16. Map and cross section showing effects of pumping from wells on water table in Stevens Point well field ... . . . . . .

17. Map showing distribution of hardness in ground water ....

18. Map showing distribution of iron in ground water

19. Graph showing pumpage for irrigation from wells and pits, 1949-60_.

20. Map showing ground-water provinces

\section{TABLES}

TABLE 1. Water budget for Portage County, Wis

2. Summary of laboratory analysis of samples from well Pt23/9/18-362, Little Plover River basin, Wisconsin.....

3. Hydraulic characteristics determined from pumping tests -

4. Yields and specific capacities of wells in the sand-plain

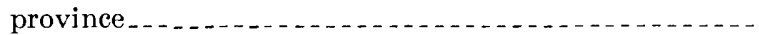

5. Yields and specific capacities of wells in the drift province

6. Selected chemical analyses of ground water in Portage County, Wis .

7. Use of ground water in ground-water provinces in Portage County, Wis., 1960 . . 


\title{
GEOLOGY AND WATER RESOURGES OF PORTAGE COUNTY, WISCONSIN
}

\author{
By C. L. R. HoLt, JR.
}

\begin{abstract}
Portage County has abundant resources of generally good quality water and, aIthough water problems exist locally, depletion or general scarcity of water is not likeIy in the foreseeable future.

The county receives annually about 31 inches of precipitation, of which about 21 inches is lost as evaportranspiration. The average annual water yield is about 10.6 inches and consists of about 10.3 inches of runoff to streams, about 0.2 inch of water which leaves the county as underflow, and about 0.1 inch of water which is used consumptively.

The surface-water resources include 104 lakes, about 110 miles of streams that discharge about $600 \mathrm{cfs}$ (culic feet per second) to the Wisconsin, Waupaca, and Little Wolf Rivers, and the Wisconsin River which has an average flow of about $2.400 \mathrm{cfs}$. Fxtensive deposits of outwash sand and gravel, sandy till, and alluvium release annually about $460 \mathrm{cfs}$ of ground water to the streams.

The principal source of ground water is thick deposits of glacial drift that occur over all but the northwestern part of the county. Although as much as 100 feet of sandstone underlies the drift in the southern part, it is not an important aquifer. Impermeable crsstalline rocks of Precambrian age underlie all the aquifers and limit the downward movement of water.

The county has been divided into areas having similar geologic and hydrologic conditions. These areas are here named the "sand-plain province," the "drift province," and the "drift-crystalline-rock province." The sand-plain province and the eastern part of the drift province have the greatest potential for development of large ground-water supplies. Wells yielding 1.000 to $2,000 \mathrm{gpm}$ (gallons per minute) can be developed in the sand-plain province and wells yielding about $500 \mathrm{gpm}$ can be developed in the drift province. Nearly all the communities in the county have water resources adequate for future expansion. An exception to this is Junction City where only a limited supply of poor quality water is readily available. Additional supplies can be developed from ground water in the Mill Creek area or from the Wisconsin River.

In the sand-plain and drift provinces, ground-water runoff is about 9 inches a sear and surface runoff is about 1 inch a year and of short duration. In the drift-crystalline-rock province. however, ground-water runoff is about 2 inches a year and surface runoff is about 8 inches a year and varies greatly in rate of flow.

Surface and ground water are closely interrelated throughout the county and constitute a single resource. Streams, lakes, and marshes are the visible part of the ground-water surface and ground water mores slowly and continuously toward these surface points of discharge.
\end{abstract}


Pumping for irrigation has temporarily lowered water levels in the vicinity of wells but has not lowered regional water levels. Pumpage has intercepted and utilized some of the recharge that would have been rapidly discharged from the aquifer, but it has not materially depleted the flow of streams. The 1955-59 decline in water levels and lake stages is attributed to a deficiency in precipitation and not to the increased pumpage from irrigation wells. To prevent excessive declines in water levels, high-capacity wells should be adequately spaced-about 2,500 feet between wells pumping $1,000 \mathrm{gpm}$ for 90 days.

In the Stevens Point area, heavy pumping of wells near the Plover River induces recharge to ground water and thus reduces local declines in the water Ievel.

The chemical quality of ground water is generally good, but, locally, hard water and undesirable amounts of iron require treatment.

\section{INTRODUCTION}

The rapidly increasing use of ground water in Portage County for industry and agriculture, the expanding population, and the rising interest in water-based recreation points to the need for a better understanding of the hydrologic system in the area. Supplemental irrigation is rapidly becoming an important use of ground water and may soon become one of the largest.

Geologic and hydrologic conditions create varied water problems in the county. Abundant water is available in most of the area except for the northwestern part of the county. Water in some areas has undesirable amounts of iron, but in nearby areas may be almost free of iron. The ground water varies from soft to very hard. Pollution is a present and potential problem in densely populated areas lacking central sewerage systems.

\section{PURPOSE}

Primarily requisites for the intelligent development of ground water are data on (1) its occurrence and distribution, (2) its recharge, discharge, and movement, (3) its relation to surface water, and (4) its quantity and quality. The purpose of this study was to collect, to evaluate, and to interpret these data in order to gain a better understanding of the ground-water resources and water problems of Portage County and to suggest possible solutions to the problems of undesirable water quality, inadequate water supply, excessive declines in water level, pollution of water, and conflict of interests. This report presents an evaluation of the ground-water resources of Portage County with respect to present and potential use. It is intended for initial guidance in the future development of water supplies in the county.

The study of the geology and ground-water resources of Portage County was begun in 1953 by the U.S. Geological Survey in cooperation with the University of Wisconsin Geological and Natural History 
Survey, as part of a statewide cooperative program of ground-water studies which was begun in 1946.

\section{LOCATION AND DEVELOPMENT}

Portage County is in central Wisconsin and lies between lat $44^{\circ} 14^{\prime}$ and $44^{\circ} 41^{\prime} \mathrm{N}$., and long $89^{\circ} 13^{\prime}$ and $89^{\circ} 51^{\prime} \mathrm{W}$. (fig. 1). The area is about 819 square miles or about 524,000 acres, of which about 8,800 acres are lakes and streams. According to the 1960 census, the population of the county was 36,964 , of which 52 percent lived in rural areas (U.S. Dept. Commerce, 1960). Stevens Point, the county seat, situated in the west-central part of the county on the Wisconsin River, is approximately 112 miles north of Madison and 90 miles west of Green Bay.

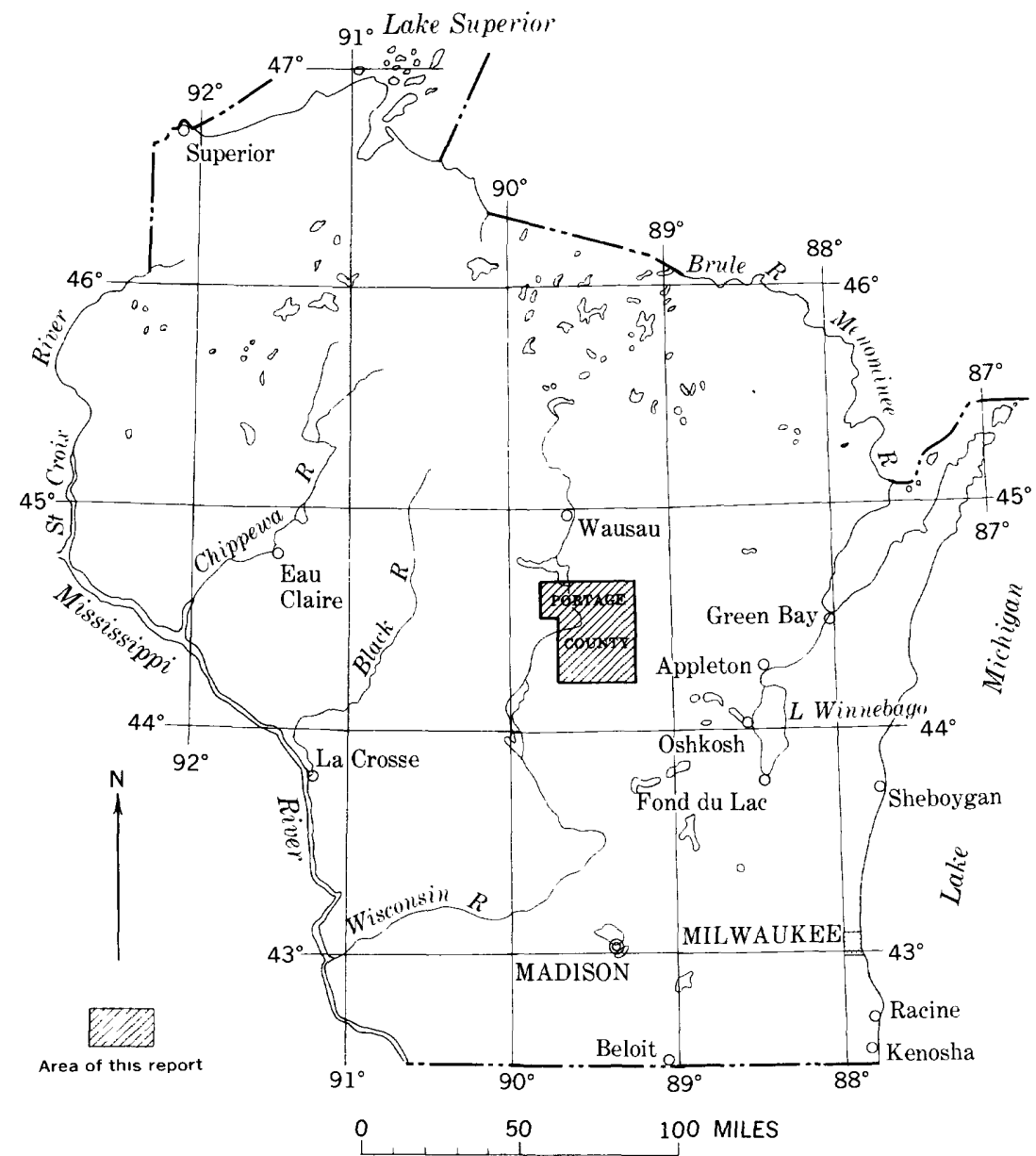

Figure 1.-Location of Portage County, Wis. 
In the early 19th century, Portage County was the scene of extensive lumbering operations, and much of the cleared land went into farms (Wisconsin Dept. Resource Devel., 1961). The Wisconsin River furnished a means of transporting logs and served as a source of power. Today, forest products are still important to the paper and woodworking industries in the county, but the timber resources now are derived from an extensive region which includes Canada.

The principal use of the land in Portage County is for agriculture. About 75 percent of the land area is in farms and about 20 percent in forest, and the remainder is occupied by communities, industries, and roadways. Potato growing and dairying are currently the largest sources of agricultural income.

Manufacturing provides more employment and income than do agriculture and forestry. Paper making and woodworking are the principal industries. The production of foods, beverages, and fishing equipment are also important. The county's 104 lakes, 110 miles of trout streams, and extensive wetlands are important habitats for fish, waterfowl, and furbearing mammals and provide outdoor enjoyment and recreation for many people. The ready availability of outdoor recreation attracts an increasing volume of tourist traffic to the county and contributes to the economy of the area.

\section{CLIMATE}

Warm, humid summers and cold, snowy winters characterize the climate of Portage County. The average annual air temperature is $44^{\circ} \mathrm{F}$, based on 61 years of record, at Stevens Point, elevation 1,113 feet; and $42^{\circ} \mathrm{F}$, based on 33 years of record, at Coddington, elevation 1,060 feet. Coddington has reported a maximum temperature of $106^{\circ} \mathrm{F}$ and a minimum of $-43^{\circ} \mathrm{F}$; similar figures for Stevens Point are $108^{\circ} \mathrm{F}$ and $-48^{\circ} \mathrm{F}$.

The total yearly precipitation averages about 32 inches at Stevens Point and about 31 inches at Coddington. Precipitation is evenly distributed throughout the county, 65 percent of the total falling during the growing season which extends from May to September. Winter precipitation is chiefy in the form of snow, the average annual snowfall being about 43 inches.

\section{PREVIOUS REPORTS}

Various aspects of the geology and hydrology of Portage County are discussed in reports of investigations made in central Wisconsin. The general geology of the area was mapped and described by Chamberlin (1877, 1883), Thwaites (1940), Martin (1932), and Bean (1949). Thwaites (1943) mapped the Pleistocene geology of the area 
and described the glacial drainage and stratigraphy. Reports containing information on ground water were prepared by Kirchoffer (1905), Weidman (1907), Weidman and Schultz (1915), Wisconsin Bureau of Sanitary Engineering (1935), and Drescher (1956).

\section{ACKNOWLEDGMENTS}

The writer wishes to thank the many persons who provided assistance and contributed the pertinent information that made this report possible. Special acknowledgment is made to Verne A. Somers, Superintendent of the Water and Sewage Utilities of Sterens Point, for supplying data on water lerels and pumpage; to well owners, well drillers, and consulting engineers for furnishing well logs, records of water levels, pumpage, and other data; to the Wisconsin State Laboratory of Hygiene for making chemical analyses of many of the water samples collected during this investigation; to the members of the Wisconsin Water Regulatory Board for information on the drainage ditches; and to Murray P. Pinkerton, Portage County Agriculture Agent, for information on the use of water for irrigation. Thanks are also expressed to Mr. G. F. Hanson, State Geologist, for his review of this report and to Mr. O. J. Muegge, State Sanitary Engineer, for supplying well records from the files of the State Board of Health.

\section{NUMBERING SYSTEM}

A three-segment system of letters and numbers is used to designate the location of wells, springs, and lakes (fig. 2). The county designation (the first segment) is derived from the county name (Pt, Portage County). The township designation within the county (the second segment) is based on the Federal system of land subdivision, and consists of the township, range, and section number. In Portage County all townships are north of the base line, and all ranges are east of the principal meridian. The letter $\mathrm{E}$ or $\mathrm{W}$ following a section number is used in oversized sections and indicates the east or west half of the section. The last segment is a serial number assigned in the order that the well was inventoried in the county. Serial numbers of springs and lakes are preceded by the letters $\mathrm{S}$ and $\mathrm{L}$, respectively. Only the serial number is shown on illustrations.

\section{HYDROLOGIC SYSTEM}

The hydrologic system in Portage County is not a closed system within the county, but is a system with many parameters independent of arbitrary boundaries. The parameters range from storm runoff entering the Wisconsin River to a cessation of flow in Mill Creek caused by below-average precipitation; from decreased evapotranspiration in drained marshland to increased evapotranspiration in 


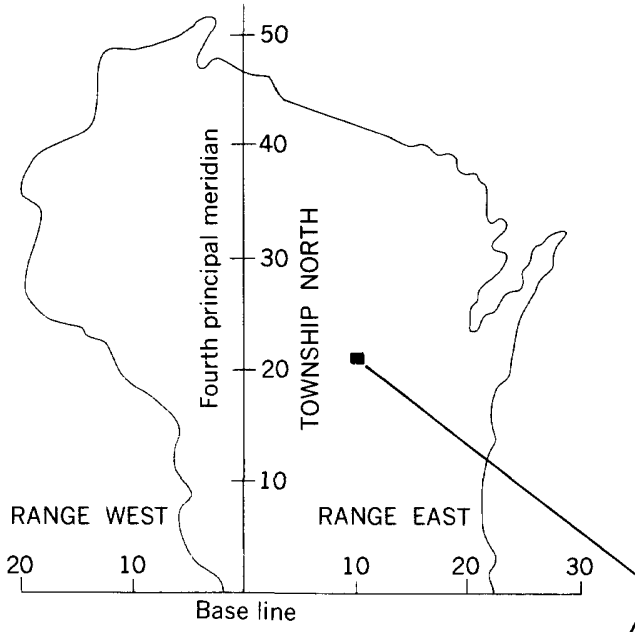

Federal system of land subdivision in Wisconsin

\begin{tabular}{|c|c|c|c|c|c|}
\hline 6 & 5 & 4 & 3 & 2 & 1 \\
\hline 7 & 8 & 9 & 10 & 11 & 12 \\
\hline 18 & 17 & 16 & 15 & 14 & 13 \\
\hline 19 & 20 & 21 & 22 & 23 & 24 \\
\hline 30 & 29 & 28 & 27 & 26 & 25 \\
\hline 31 & 32 & 33 & 34 & 35 & 36 \\
\hline
\end{tabular}

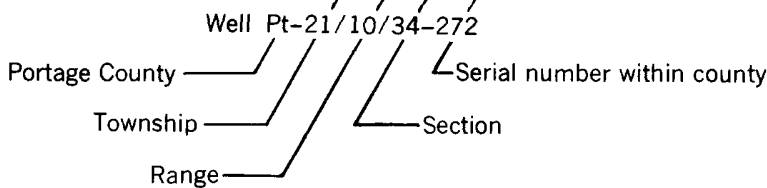

Figure 2.-Well numbering system in Wisconsin. 
irrigated fields; and from dams on the Wisconsin River to industrial and municipal pumpage from wells adjacent to the Plover River. An understanding of the hydrologic system in Portage County requires an understanding of the processes that influence the water cycle in a very broad area.

The water system is dynamic and changes with time and the works of man. Depths to water in wells, stages of lakes, soil moisture, evapotranspiration, and flow of streams vary with short- and long-term changes in precipitation. Pumpage of water, drainage of wetlands, construction of dams, cultivation of crops, and control of forests constantly change the water system and may create water problems.

\section{SOURCE OF WATER}

The source of all water in Portage County is precipitation in the form of rain, snow, sleet, or hail. Much of the precipitation is returned to the atmosphere by evaporation from soil and transpiration from plants, commonly considered together as "evapotranspiration," but the remainder flows overland to surface streams, replenishes soil moisture, or percolates downward to the zone of saturation. Ground water does not move in well-defined underground channels, but percolates through pore spaces and fractures in the water-bearing formations from areas of recharge toward areas of discharge.

In addition to the precipitation that falls on the county, the large flow of the Wisconsin River is available for use. There is no appreciable underground flow of water into the county.

The total yearly precipitation on Portage County averages about 31.4 inches of water, and represents a flow of about 1,900 cfs (cubic feet per second). The estimated average discharge of the Wisconsin River as it passes the northern boundary of the county is about 2,400 cfs.

\section{WATER BUDGET}

A generalized water budget of Portage County (fig. 3) accounts for the quantities of water in various environments in the hydrologic system and indicates in a general way the relations among several components of the system. The quantities of water are expressed in inches. The water budget does not include the $2,400 \mathrm{cfs}$ average flow of the Wisconsin River that enters Portage County.

The annual excess of precipitation over estimated evapotranspiration is about 10.6 inches, or about 465,000 acre-feet, and is called the average annual water yield of the county. The water yield consists of surface- and ground-water runoff, underflow, and consumptive water use. The data on precipitation, evapotranspiration, and water yield in Portage County are summarized in table 1 and discussed in subsequent sections of this report. 
8 GEOLOGY, WATER RESOURCES, PORTAGE COUNTY, Wis.

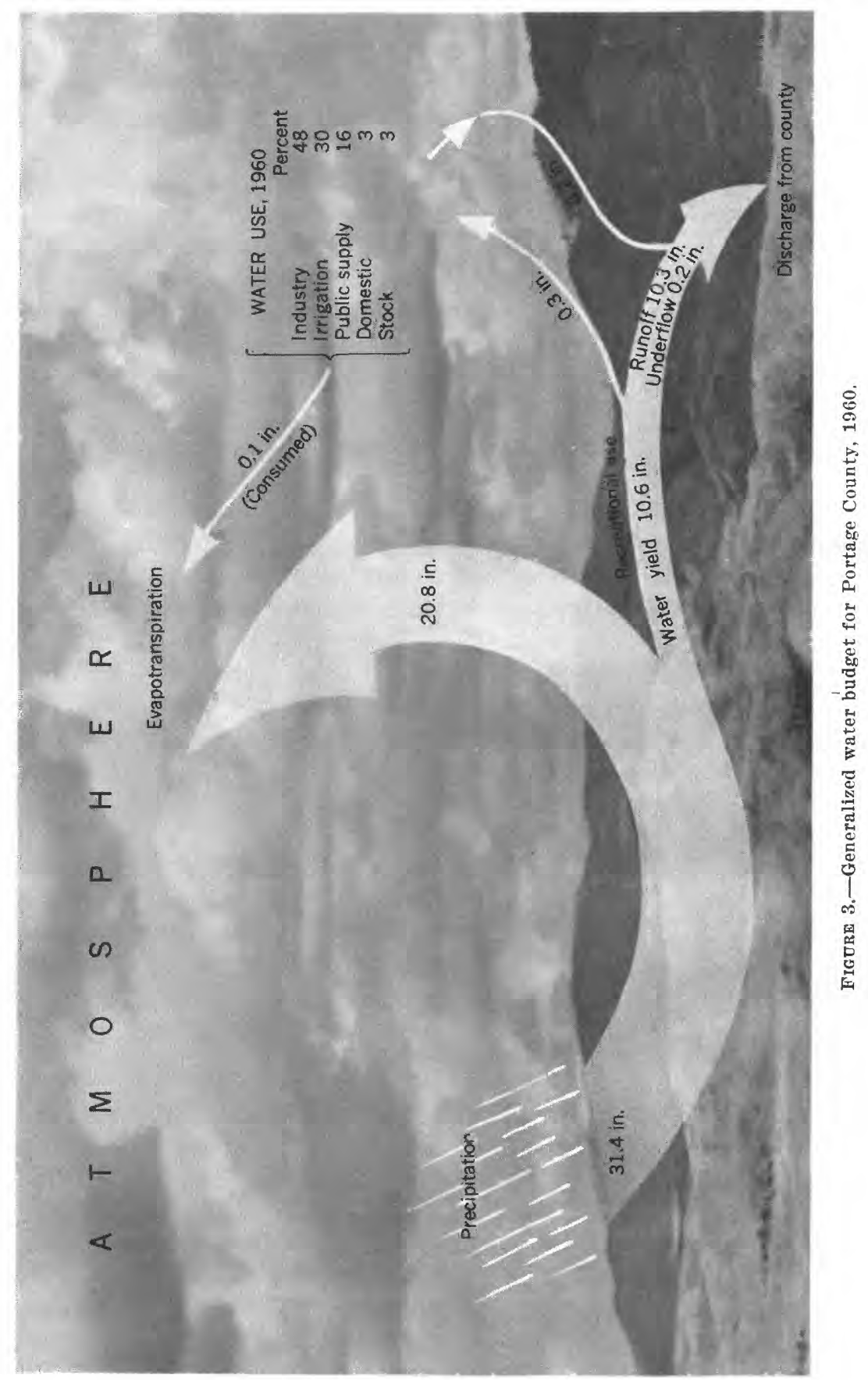


TABLE 1.-Water budget for Portage County, Wis.

\begin{tabular}{|c|c|c|c|c|c|}
\hline \multirow{2}{*}{ Gain - loss $=$ yield } & \multirow{2}{*}{$\begin{array}{c}\text { Inches } \\
\text { per } \\
\text { year }\end{array}$} & \multicolumn{2}{|c|}{ Area } & \multirow{2}{*}{$\begin{array}{c}\text { Acre-feet } \\
\text { per year } \\
(1,000)\end{array}$} & \multirow{2}{*}{$\mathrm{Cfs}$} \\
\hline & & $\begin{array}{l}\text { Square } \\
\text { miles }\end{array}$ & $\begin{array}{r}\text { Acres } \\
(1,000)\end{array}$ & & \\
\hline Gain, precipitation & 31.4 & 819 & 524 & 1,375 & 1,890 \\
\hline Loss, evapotranspiration average & 20.8 & 819 & 524 & 910 & 1,250 \\
\hline Evapotranspiration, surface water & 31 & 69 & 44 & 110 & 150 \\
\hline Evapotranspiration, soil water $\ldots \ldots$ & 20 & 750 & 480 & 800 & 1,100 \\
\hline Yield & 10.6 & 819 & 524 & 465 & 640 \\
\hline Runoff average & 10. 3 & 819 & 524 & 450 & 620 \\
\hline Wisconsin River.... & 10. 2 & 505 & 323 & 275 & 380 \\
\hline Waupaca River.............. & 10.5 & 233 & 149 & 130 & 180 \\
\hline Little Wolf River & 10.2 & 81 & 52 & 45 & 60 \\
\hline Ground-water underflow & .2 & 01 & ......... & 10 & 14 \\
\hline Consumptive use, 1960 & & & & 5 & 6 \\
\hline
\end{tabular}

\section{EVAPOTRANSPIRATION}

The loss of water to the atmosphere by evapctranspiration from surface-water bodies, soil moisture, and ground water constitutes an important part of the hydrologic cycle (fig. 3). Some of man's uses of water, such as irrigation with sprinklers, also return water to the atmosphere and are included with evapotranspiration. In general, evapotranspiration is greatest from surface-water bodies and least from areas where evapotranspiration is solely from soil moisture. The water that leaves the county in streams or by underflow is not considered water loss because it becomes arailable to downstream users.

\section{EVAPOTRANSPIRATION OF SURFACE WATER}

Evapotranspiration from lakes, streams, and marshes is about equal to the average annual precipitation. The estimated annual rate of evapotranspiration from about 44,000 acres covered by surface-water bodies is about 110,000 acre-feet.

\section{EVAPOTRANSPIRATION OF SOIL WATER}

Although the annual evapotranspiration from soil moisture has not been measured directly in the county, studies by C. B. Tanner (written commun., 1957) of the net transfer of heat energy between cropland and the atmosphere near Hancock, Wis., showed that between 20 and 21 inches of water were lost to evapotranspiration. The Hancock study area is 7 miles south of Portage County and has the same general soil characteristics, topography, geology, and depth to water table as in the central and southwestern parts of Portage County.

The difference between average annual precipitation and average annual water yield, about 20 inches, is assumed to be the average annual rate of evapotranspiration from soil moisture (table 1). The estimated volume of soil water lost annually by erapotranspiration from 480,000 acres of land surface is about 800,000 acre-feet. 
The average annual rate of evapotranspiration from surface-water bodies (about 31 inches per year) and from soil moisture and ground water ( 20 inches per year) is about 21 inches or about 910,000 acrefeet (table 1). The annual loss of water through evapotranspiration is about 66 percent of the average yearly precipitation that falls on the county.

About 6 inches of precipitation accumulates annually on the surface in the form of snow and ice. C. B. Tanner (written commun., 1957) estimates that about 0.5 inch of water per month evaporates from the snow or about 2 inches during the period of November through March. The loss of water that evaporates from snow probably is balanced in part by the gain of water that returns to the land surface as frost during cold nights. The evaporation loss is also partly balanced by moisture that condenses out of the warm, humid air into the snow during periods of rapid snowmelt.

\section{POTENTIAL EVAPOTRANSPIRATION}

Direct measurement of evapotranspiration is extremely difficult. Therefore, an estimate of potential evapotranspiration was made by using Thornthwaite's empirical relationship between potential evapotranspiration and mean air temperature (Palmer and Havens, 1958, p. 123-128). Potential evapotranspiration is defined as the amount of water that would be lost from a surface covered by vegetation if there were no soil moisture deficiency. By using mean air-temperature data collected at the Stevens Point and Hancock weather stations, annual potential evapotranspiration was computed as being about 24.5 inches (fig. 4). Annual potential evapotranspiration from soil moisture is about 5 inches greater than the estimated annual rate of evapotranspiration determined from the water budget.

\section{SOIL-MOISTURE DEFICIENCY}

A comparison of the estimated potential evapotranspiration with the measured precipitation at the Stevens Point and Hancock stations (fig. 4) shows that about 4.5 inches of water would be lost to evapotranspiration during June, July, and August, the principal months of the growing season, if the soil moisture were always at field capacity. Under nonirrigation growing conditions, soil moisture is generally below field capacity. Tanner (written commun., 1957) reports that, when the soil is at field-moisture capacity, plants can extract as much as 0.8 inch of water per foot of soil. Potatoes, vegetable crops, and grains extract water from about 2 feet of soil. The potential soilmoisture deficiency for such crops is therefore about 1.5 inches. 


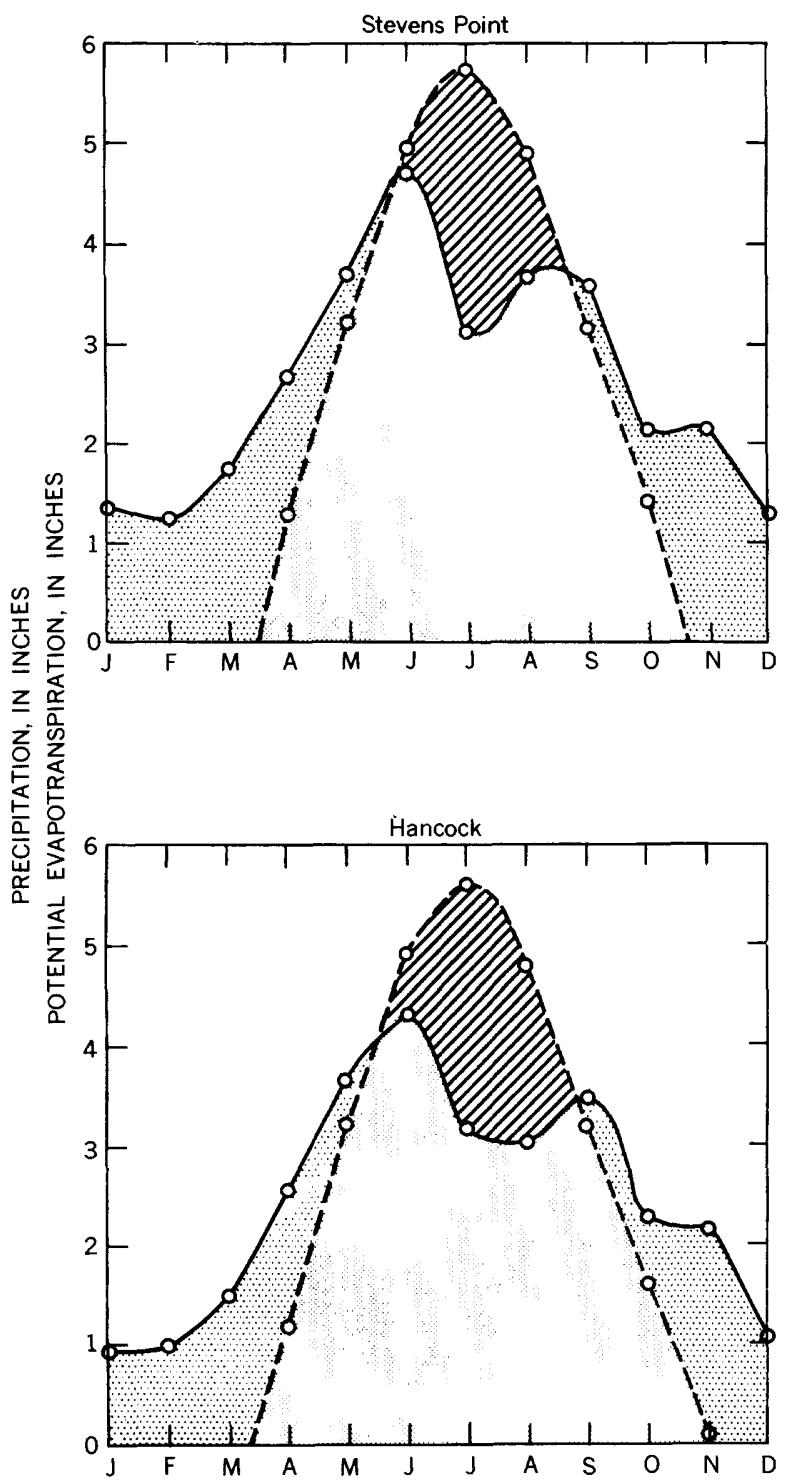

\section{EXPLANATION}

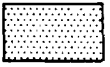

Potential water for soil moisture and groundwater rechargè

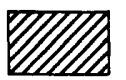

Water deficiency

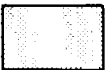

Evapotranspiration

Mean precipitation

Potential

evapotranspiration

Figure 4.-Comparison of precipitation to estimated potential evapotranspiration at Stevens Point and at Hancock, Wis. (Precipitation data from U.S. Weather Bureau.) 
This deficit of soil moisture is partially replaced during September, October, and November when precipitation exceeds potential evapotranspiration by about 3 inches. In the spring after the snow has melted and the ground has thawed, precipitation exceeds evapotranspiration and soil moisture is at field capacity. When the soil-moisture capacity of the soil is exceeded, ground water will be recharged and overland runoff may occur.

Supplemental irrigation replenishes the soil moisture that has been depleted by evapotranspiration. During the 1960 growing season, about 5 inches of water was applied by sprinklers to potatoes and to other erops. This amount of water, applied periodically, restored the soil to its field-moisture capacity, and any excess water evaporated or returned to ground water. Most of the water used in 1960 for irrigation was returned to the atmosphere by evapotranspiration.

\section{INTERRELATION OF SURFACE AND GROUND WATER}

Surface and ground water are so closely related in Portage County that neither can be considered as a separate source of supply. Changes in precipitation, recharge, evapotranspiration, discharge, drainage, and storage are reflected by changes in ground- and surface-water runoff.

To illustrate the interrelation of surface water and ground water in Portage County, consider a typical year beginning in January. At this time of the year the land surface is frozen and covered with snow, and vegetation is dead or dormant. Streamflow is low and is derived almost entirely from the ground-water reservoir. The water table declines because of the lack of recharge and the constant discharge to the streams. The stages of lakes, streams, and water in wetlands also decline. In the spring, the melting of snow, ice, and frost in the ground restores soil moisture, recharges ground-water reservoirs, and runs off on the surface to streams. Water is ponded in wetlands and a major rise occurs in the water table and in the stages of lakes and streams. The rate of runoff is high and flooding may occur.

The growing season begins and water is discharged from the water bodies by evaporation and from the soil by evapotranspiration. During this season, the ground-water reservoir continues to discharge to the streams. Because there is little recharge to the ground-water reservoir, except after heavy extended rains, the water table and lake stages decline and streamflow decreases.

The discharge of streams during the growing season may fluctuate daily because evapotranspiration decreases daily the amount of ground 
water that is flowing toward the streams. Ground-water pumpage increases for nearly all uses.

With the first killing frost in the fall, the discharge of water by evapotranspiration is greatly diminished. Rainfall rapidly replenishes soil moisture, and an appreciably large rainfall is accompanied by recharge to the ground-water reservoir, by a rise in the water table and in the stages of lakes and wetlands, and by increased runoff. With the freezing of the ground in early winter, the possibility of recharge ceases, the water table and lake levels decline, and streamflow is reduced; these conditions continue until the next spring thaw.

The interrelations of ground water and surface water must be understood in planning for the wise management of the county"s water resources. These same interrelations should be taken into consideration in formulating legislative controls of the diversion of ground and surface water.

\section{SURFACE WATER}

The large flow of the Wisconsin River passes through Portage County, and the county is drained by numerous other streams. It also has poorly drained areas that contain many lakes and wetlands and areas where recharge from precipitation is so rapid that there is little surface runoff.

The western two-thirds of the county drains to the Wisconsin River and the eastern third of the county drains to the Waupaca and Little Wolf Rivers. The bulk of the water that flows to these streams comes from seepage of ground water along the stream channels, but some of the water comes from surface runoff during and after storms.

\section{DRAINAGE BASINS}

No single boundary such as a topographic divide delineates the Wisconsin River, the Waupaca River, or the Little Wolf River drainage basins as such (fig. 5). Instead, the topographic divides limit the areas contributing surface runoff to the streams, whereas the ground-water divides limit the areas contributing ground water. The ground-water divide between the Wisconsin and the Waupaca River basins follows the general trend of the Outer moraine, whereas the topographic divide approximates the trend of the Second moraine (figs. 5 and 8 ).

An area of hills and undrained depressions underlies the groundwater divide and contributes virtually no surface runoff. This noncontributing area includes about 250 square miles and extends 2 to 3 miles on both sides of the divide. Precipitation not lost to evapotranspiration either percolates downward through the sandy soil to the ground-water reservoir or runs off overland to a depression in the 
land surface. The water stored in the depression moves downward slowly and recharges the ground-water reservoir during a period of days.

In the Waupaca River drainage basin, the ground-water contribution comes from an area that is about 36 square miles larger than the surface-runoff area (fig. 5). In the northern third of this basin, the area of surface runoff is about 6 square miles larger than the area of ground-water runoff, whereas in the southern two-thirds of the basin, the area of surface runoff is about 42 square miles smaller than the area of ground-water runoff.

The ground-water divides probably approximate the limits of the drainage basins; they have been used in this report for computations of runoff from drainage basins and for estimation of the water resources within basins.

The positions of the ground-water divides are not fixed as are the

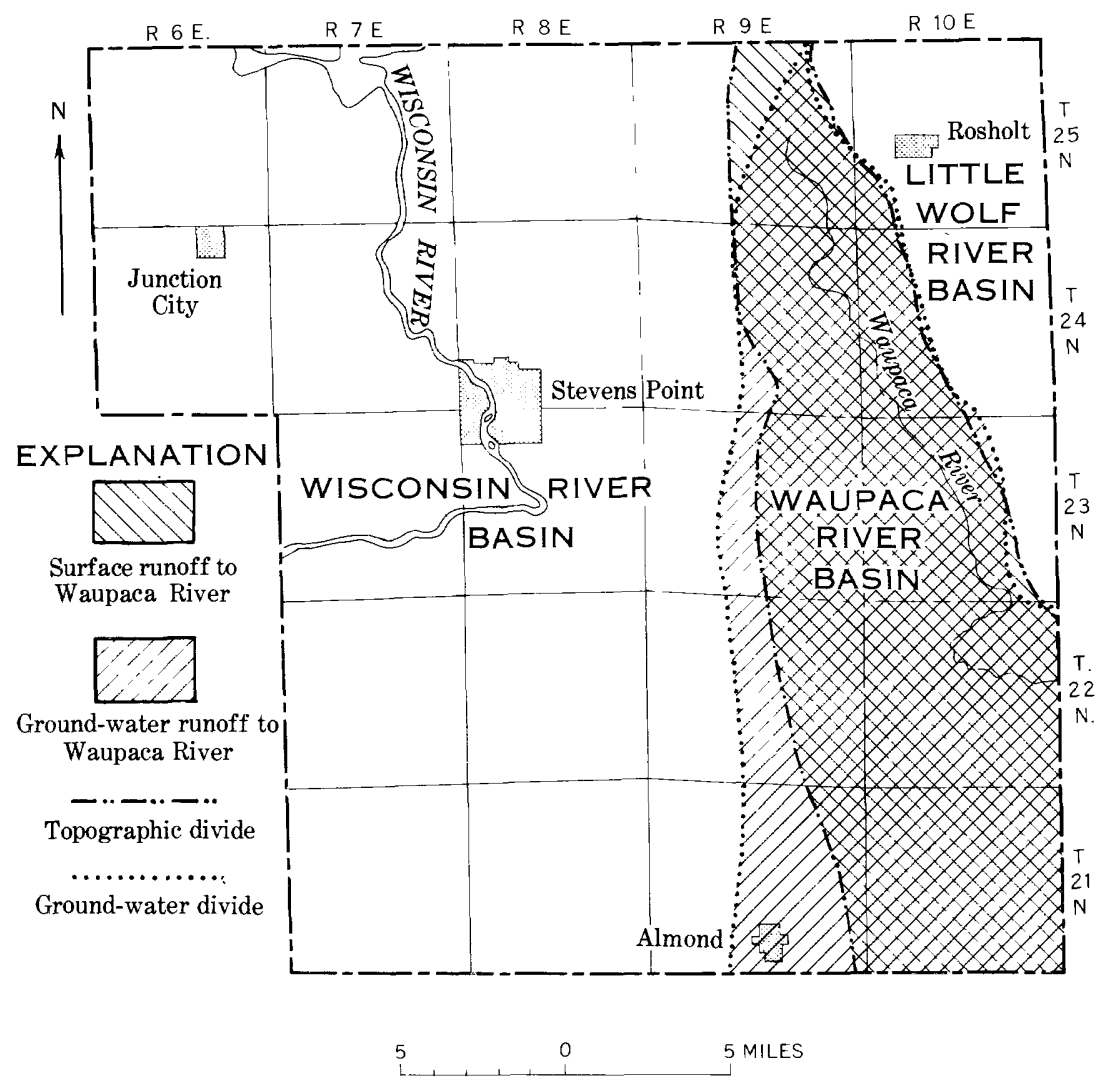

Figdre 5.- Map of Portage County showing hydrologic divides between Waupaca, Wisconsin, and Little Wolf Rivers drainage basins. Base from Wisconsin Highway Commission road map. 
topographic divides, but may shift when the amount and distribution of rainfall is uneven or when water is withdrawn by wells. For all practical purposes, the divides shift only insignificant distances because rainfall and recharge are generally constant. But in the Almond area where pumpage from wells is increasing the ground-water divide may shift an appreciable distance.

\section{WISCONSIN RIVER BASIN}

The Wisconsin River drains two geologically different areas in the county: the sand-plain area consisting of thick deposits of sand and gravel, and the northwestern area that has a bedrock surface of crystalline rock covered locally by a thin layer of drift. Although the slope of the land is gentle in both areas, the streams from the sandplain area have better sustained flow than do the streams draining the northwestern area.

The sand-plain area, extending over about 302 square miles in central and southwestern Portage County, is bounded on the east by the terminal moraines (figs. 8 and 20). The land slopes 3 to 15 feet per mile west from the moraines (fig. 8 ) to the Wisconsin River. The area is drained by the Plover and Little Plover Rivers and the Hay Meadow Creek in the north and by Buena Vista, Fourmile, and Tenmile Creeks, connected to a system of drainage ditches, in the south (pl.1).

On the basis of 3 years of daily flow measurements made at a gage at Plover, the average annual discharge from 12 square miles of the Little Plover River basin is $9.2 \mathrm{cfs}$, or about 10.4 inches per square mile. A graph of the duration of flow, figure 6 , indicates that streamflow was derived mainly from ground-water runoff.

The estimated average discharge from the 76 square miles of the Plover River basin in Portage County, based on 12 years of daily flow measurements at a gage near Stevens Point, is about $70 \mathrm{cfs}$. The average ground-water runoff per square mile to this stream is probably less than it is to the Little Plover River because extensive swamps and marshes in the Plover River basin limit recharge and are areas of high evapotranspiration.

A series of east-west drainage ditches, constructed at approximately 1-mile intervals, drain about 162 square miles of the sand-plain area in the southwestern part of the county. Dams constructed at regular intervals along the ditches regulate the stage of the streams. The ditches connect with the Buena Vista, Fourmile, and Tenmile Creeks which discharge to the Wisconsin River in Wood and Adams Counties.

The runoff from the 162 -square-mile area drained by ditches is estimated to average about $115 \mathrm{cfs}$. Extensive marshes and a shallow water table in parts of the area reject further recharge and increase evapotranspiration. 


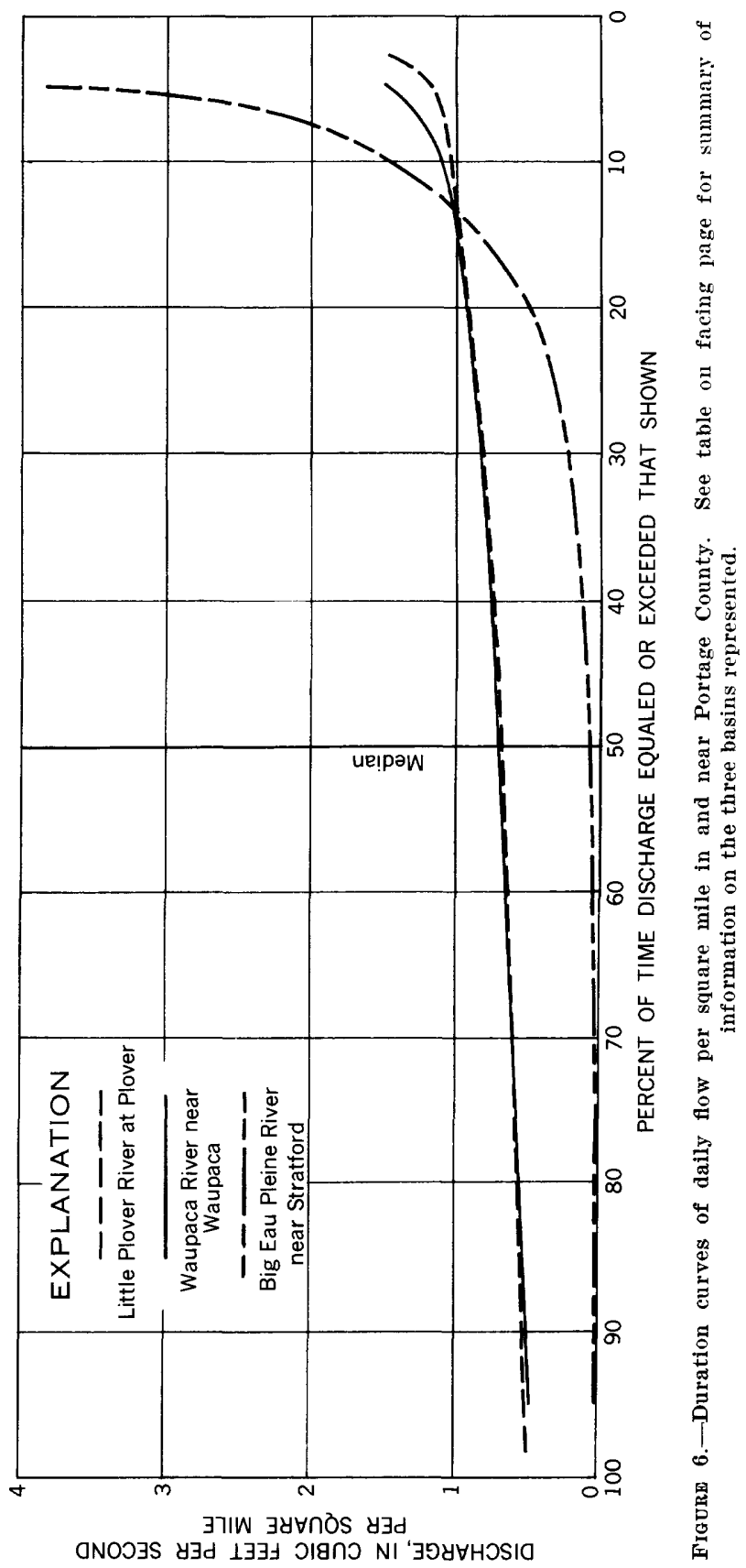


Summary of information on the basins represented on figure 6

\begin{tabular}{|c|c|c|c|c|c|}
\hline River & $\begin{array}{c}\text { Drainage } \\
\text { area } \\
\text { (sq } \mathrm{mi})\end{array}$ & $\begin{array}{l}\text { Records } \\
\text { used }\end{array}$ & $\begin{array}{c}\text { A verage } \\
\text { annual } \\
\text { discharge } \\
\text { (cfs per } \\
\text { sq mi) }\end{array}$ & Geology & Hydrology \\
\hline $\begin{array}{l}\text { Little Plover River } \\
\text { at Plover. }\end{array}$ & 12 & $1959-62$ & 0.77 & $\begin{array}{l}\text { Thick deposits of flat- } \\
\text { lying outwash, and } \\
\text { some peat and allu- } \\
\text { vium, are underlain } \\
\text { by crystalline rock. }\end{array}$ & $\begin{array}{l}\text { Ground-water runoff } \\
\text { is large. Surface } \\
\text { runoff is small and of } \\
\text { short duration. } \\
\text { During } 95 \text { percent of } \\
\text { time, streamflow is } \\
\text { from ground-water } \\
\text { runoff. During dry } \\
\text { periods, the dis- } \\
\text { charge per square } \\
\text { mile ranges from } \\
0.5 \text { to } 1.0 \mathrm{cfs} \text {. }\end{array}$ \\
\hline $\begin{array}{c}\text { Waupaca River } \\
\text { near Waupaca. }\end{array}$ & 305 & $1917-54$ & .78 & $\begin{array}{l}\text { Thick deposits of sandy } \\
\text { till, outwash, and } \\
\text { alluvium underlain } \\
\text { by sandstone and } \\
\text { crystalline rock. }\end{array}$ & $\begin{array}{l}\text { Ground-water runoff is } \\
\text { large. Surface runoff } \\
\text { is small and of short } \\
\text { duration. During } \\
\text { about } 90 \text { percent of } \\
\text { time, streamflow is } \\
\text { from ground-water } \\
\text { runoff. During dry } \\
\text { periods, the discharge } \\
\text { per square mile ranges } \\
\text { from } 0.5 \text { to } 1.0 \mathrm{cfs} \text {. }\end{array}$ \\
\hline $\begin{array}{l}\text { Big Eau Pleine } \\
\text { River near Strat. } \\
\text { ford. }\end{array}$ & 224 & $1938-54$ & .75 & $\begin{array}{l}\text { Thin deposits of clay } \\
\text { till, outwash, and } \\
\text { alluvium over crys- } \\
\text { talline rock. }\end{array}$ & $\begin{array}{l}\text { Ground-water runoff } \\
\text { is small. Surface } \\
\text { runoff is large. Dur- } \\
\text { ing about } 75 \text { percent } \\
\text { of time, streamflow } \\
\text { is from ground-water } \\
\text { runoff. During dry } \\
\text { periods, the discharge } \\
\text { per square mile ranges } \\
\text { from } 0.0 \text { to } 0.2 \mathrm{cfs} \text {. }\end{array}$ \\
\hline
\end{tabular}

The average flow of Hay Meadow Creek and the runoff from several small drained marshes are estimated to be about $26 \mathrm{cfs}$. The estimated average runoff from the 302 -square-mile area of the sand-plain area is about $220 \mathrm{cfs}$.

The drainage of the northwest area is poor to moderate, the principal streams being the Little Eau Pleine River, Mill, Bear, and Rocky Run Creeks, all draining into the Wisconsin River. Approximately 27 percent of the 203 square miles of this area is marsh and swamp. The only lakes in the area are the Du Bay and Stevens Point reservoirs on the Wisconsin River.

The geologic and hydrologic characteristics of the northwestern part of Portage County are very similar to those of the Big Eau Pleine River basin in Marathon County. The geology of both areas consists of thin deposits of clay till, outwash, and alluvium overlying crystalline rocks, and the ground-water runoff from both areas is small and the surface runoff is large. For these reasons, the discharge characteristics of the Big Eau Pleine River, as determined from 16 years of daily flow measurements made at a gage near Stratford (fig. 6; U.S. Geol. Survey, 1962), are used to estimate ground- and surfacewater runoff in the northwestern part of Portage County. 
The discharge of the streams that drain the northwestern part of the county is very large during and immediately after storms and small during the remainder of the time (fig. 6). The average discharge from this area is about $150 \mathrm{cfs}$. The median discharge (discharge at 50 percent of the time) is estimated to be about $0.06 \mathrm{cfs}$ per $\mathrm{sq} \mathrm{mi}$ or about $12 \mathrm{cfs}$ from the 203 -square-mile area in northwestern Portage County. The discharge at 10 percent of the time (often taken as an index of low flow) is estimated to be about 0.02 cfs per sq mi.

The estimated average discharge of the Wisconsin River as it passes the northern boundary of the county is about $2,400 \mathrm{cfs}$ (based on 192941 discharge measurements made at Knowlton). As the river passes Stevens Point and Whiting, the Plover and Little Plover Rivers and Hay Meadow Creek add an a verage of about $105 \mathrm{cfs}$, and the streams draining from the northwest add an estimated average of about 150 cfs to the river's discharge.

The estimated average runoff from the 505 square miles of the Wisconsin River basin in Portage County, including the area of drainage ditches, is about $370 \mathrm{cfs}$.

\section{WAUPACA RIVER BASIN}

The Tomorrow River and the Poncho, Bear, Spring, Allen, Emmons, Murry, and Radley Creeks drain 233 square miles in the eastern part of the county and form the headwaters of the Waupaca River. The Waupaca River flows through the towns of Nelsonville and Amherst, then leaves the county and flows across Waupaca County to the Little Wolf and Fox Rivers and eventually to Lake Michigan. In Portage County, the land surface of the Wraupaca River drainage basin slopes about 20 feet per mile.

The discharge of the Waupaca River is derived from ground-water runoff on the basis of 38 years of daily flow measurements made at a gage near Waupaca (fig. 6; U.S. Geol. Survey, 1962).

The average yearly discharge from the 233 square miles of the Waupaca River basin in Portage County is estimated to be about $175 \mathrm{cfs}$. The average flow of the Waupaca River as it leaves the county is about $100 \mathrm{cfs}$. Allen, Emmons, Murry, and Radley Creeks drain east from the county and enter the Waupaca River above the gage near Waupaca. These streams have an estimated combined arerage flow of about. 75 cf's as they leave the county.

\section{IITTLE WOLF RIVER BASIN}

The Flume, Bradley, Nace, and Sannes Creeks, headwaters of the Little Wolf River, drain about 81 square miles of the northeastern 
part of the county. The average rate of discharge from the county is estimated to be about $60 \mathrm{cfs}$ (table 1 ). The drainage is poor because about 20 percent of the area is in wetlands and lakes.

The rumoff characteristics of the Little Wolf River are approximately the same as those of the Waupaca River because the Portage County parts of the two basins are geologically and hydrologically similar.

\section{LAKES}

Of the 104 lakes in the county, 95 are in the Waupaca and Little Wolf River drainage basins (Wisconsin Conservation Department, 1958). Most of these lakes are in depressions (called kettles or pits) in drift. Lakes are present in all the depressions that extend below the water table. The surface of the kettle lakes is, in effect, a visible part of the ground-water table. The fluctuation of the lake stage is closely associated with the fluctuation of the surrounding groundwater table.

An inventory of 42 lakes in the eastern part of the county indicated that 31 of them have neither surface inlet nor surface outlet. Lake Emily has a small inlet from the west and no outlet; Adams, Twin, Helen, Kiallana, Meyers, and Rheinhardt Lakes have outlets but no inlets. Tree, Spring, Dean, and Rough Lakes have both inlets and outlets.

\section{WETLANDS}

Wetlands are areas that are covered with shallow water or are subject to intermittent flooding and subsequent slow drainage; they generally contain organic materials. Wetland is classed generally as marsh if covered with grass, or as swamp if covered with trees, depending upon which type of corer predominates. Organic and inorganic deposits in marshes and swamps are termed "marsh deposits" in this report.

Marshes in Portage County are similar to lakes in that both have water surfaces that are visible parts of the ground-water table. The water surface of the marsh is at, or slightly above, the land surface during part of the year, but the land surface may be dry during drought periods. Many marshes are remnants of shallow lakes filled with peat, clay, and vegetation. The marshes occur in very flat areas having poor surface drainage, in depressions in the land surface, and along the margins of lakes and streams.

The wetland area of the county varies from season to season, from drought to wet period, and as drainage ditches are developed. Drainage ditches have reduced the area of wetlands in the county from about 20 percent of the total area in 1900 to about 7 percent in 1960 . 
Prior to 1902, approximately 30 percent of the southwestern part of the county was wetland and was covered by marsh vegetation. From 1902 to 1904, land developers dug a series of east-west ditches and drained most of the marsh. Leopold (1949, p. 100) described the drainage as follows:

They envisaged farms not only around, but in the marsh. An epidemic of ditchdigging and land-booming set in. The marsh was gridironed with drainage canals, speckled with new fields and farmsteads.

But crops were poor and beset by frosts, to which the expensive ditches added an aftermath of debt. Farmers moved out. Peat beds dried, shrank, caught fire.

After several decades of poor crops and burning peat, the Works Progress Administration was assigned the task of restricting flow of the drainage ditches. From 1934 to 1936 , numerous check dams were installed to regulate the stage of water in the ditches and to wet the soil.

\section{GROUND WATER}

The water that escapes initial evapotranspiration and surface runoff and is not required to replenish soil moisture moves downward into underlying materials until it reaches the water table-a surface below which all the openings in rocks are saturated with water under hydrostatic pressure.

The water-saturated rocks underlying Portage County form groundwater reservoirs, or aquifers, that store water, supply water to wells, and discharge water to streams, marshes, and lakes. A thorough knowledge of the geology and water-yielding characteristics of the aquifers is necessary for an evaluation of the hydrologic system in the county.

The water in aquifers is unconfined where water levels in shallow wells approximate the position of the water table. When the water table is lowered, some of the aquifer is dewatered, and when the water table rises, unsaturated materials become saturated. Ground water that is thus unconfined is said to occur under water-table conditions.

Water-table conditions exist in nearly all parts of Portage County. Well drillers have reported no substantial changes in water level during the drilling of wells that penetrate the sand and gravel aquifers. The only substantial changes in water level that were reported occurred during the drilling of a few wells that penetrated deposits of till.

In a few places in the county, layers of clay and relatively impermeable till overlie an aquifer, and water is confined in the aquifer under pressure. Recharge to the confined aquifer is derived at an altitude higher than the base of the overlying impermeable beds. If a well is drilled into such a confined aquifer (termed "artesian"), the 
water in the well will rise above the top of the aquifer. Such conditions of ground-water occurrence are not common in Portage County.

\section{ROCKS AND THEIR WATER-YIELDING CHARACTERISTICS}

The geology of the county influences the occurrence and availability of ground water and the nature of fluctuations of water levels in wells. It is also an important factor in the development of soil and topography and, thus, affects the proportion of surface runoff and recharge to ground water. In general, the surface runoff will be greater, and the recharge less, in an area of steep hills and well-defined valleys than in a level area or in one of gently rolling hills. Runoff is also greater from a clay soil than from a sandy soil.

Portage County is underlain by crystalline rocks of Precambrian age and sandstone of Cambrian age which are mantled generally by glacial deposits of Pleistocene age. A geologic map (pl.1) shows the surficial deposits and bedrock exposed at the surface. The map is based on reports and maps made by Hole (1943), Thwaites (1943), and Weidman (1907) ; on field observations made by the author; and on interpretation of aerial photographs. Subsurface geologic relationships are illustrated by north-south and east-west cross sections (pl. 1).

\section{CRYSTALLINE ROCKS}

Impermeable crystalline rocks of Precambrian age underlie all the aquifers in the county and limit the downward movement of water (pl. 1). The crystalline rocks consist largely of granite; however, gneiss, schist, shale, greenstone, and quartzite crop out in the northern part of the county (pl. 1). Near Junction City, a large area of ironfree quartzite grades south into an iron oxide-rich quartzite. Greenstone (augite-andesite) appears to be intrusive into the quartzite, whereas granite is intrusive into both the quartzite and the greenstone. Gneiss and schist crop out along the Wisconsin River near Plover. Dikes of coarse-grained granite intrude the gneiss and schist.

In the northwestern part of the county, the crystalline rock is exposed and weathered and contains locally enlarged joints and fractures. The fractures may extend for some distance laterally, but they are generally less than 50 feet deep. The directions of major jointing $\operatorname{are} \mathrm{N} .75^{\circ} \mathrm{W}$. and $\mathrm{N} .70^{\circ} \mathrm{E}$.

The crystalline rock is probably impermeable in all but the northwestern part of the county where drift is thin or absent. Although ground water accumulates in fractures and shallow weathered zones of the crystalline rock, it is considered to be part of the same water body as in the overlying drift. Most wells are drilled or dug less than 30 feet into the rock, and they yield generally less than 5 gpm (gallons 
per minute). A few wells, such as wells Pt-24/6/2-109, Pt-25/7/22171 , and $\mathrm{Pt}-21 / 8 / 20-233$ that yielded more than $30 \mathrm{gpm}$, tapped the crystalline rocks but obtained their water from overlying deposits of silt, sand, and gravel.

The surface of the crystalline rock resembles a broad plain that slopes approximately 10 feet per mile, from the northwestern part of the county to the south and southeast (fig. 7). The total relief is approximately 300 feet. The general shape of the surface is that of a broad shield, which plunges gently to the south (section $A-A^{\prime}$, pl. 1). In the southern part of the county, little information is available on the depth to crystalline rock because desired yields of water are obtained from shallow wells in the overlying sand and gravel aquifer.

Data from records of wells and test holes indicate that a major bedrock valley, possibly the channel of the pre-Pleistocene Wisconsin

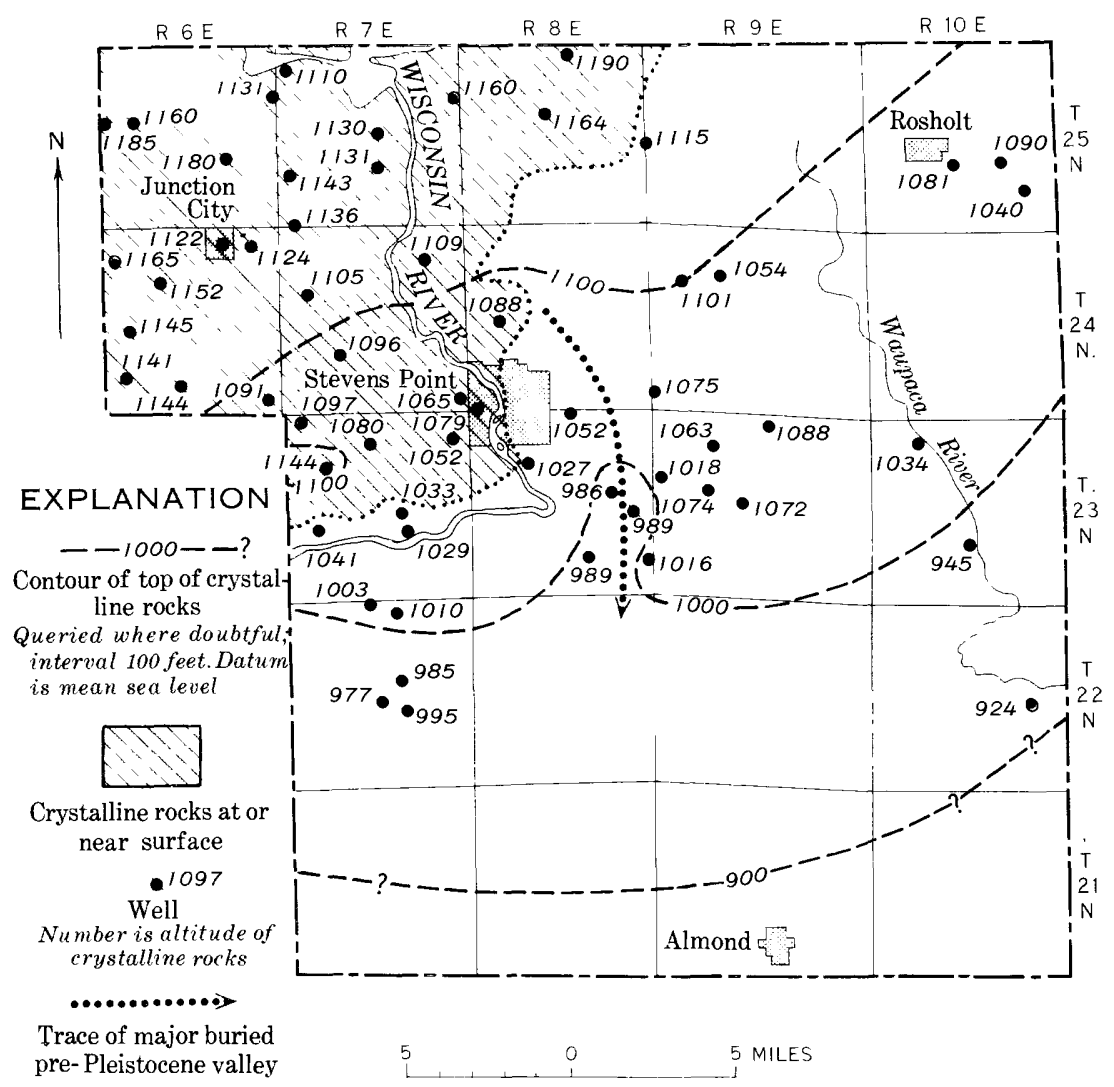

Figure 7.-Map of Portage County showing approximate altitude of surface of crystalline rocks. Base from Wisconsin Highway Commission road maps. 
River, occurs 3 to 4 miles east of the present Wisconsin River (fig. 7). Information is not available to determine the course of this channel.

\section{SANDSTONE}

Sandstone of the Dresbach Group of Late Cambrian age overlies crystalline rocks in the southern part of Portage County. The sandstone consists largely of medium to coarse grains of quartz partially cemented by silica and iron oxide. It is fairly uniform in composition but varies widely in type and amount of comentation. Poor sorting of the sand grains, ripple marks, and conspicuous cross bedding suggest shallow-water deposition. The beds range in thickness from a few inches to several feet. Joints are numerous, the principal direction of jointing being N. $65^{\circ} \mathrm{E}$. The sandstone decreases in thickness from an estimated 200 feet along the southern boundary of Portage County to 0 feet in most of the central and northern parts of the county. Thick deposits of drift cover the sandstone except in the areas where sandstone ridges or mounds protrude above the drift surface (pl.1).

A few sandstone mounds, remnants of the standstone that once covered the area, occur in the central and northwestern parts of the county. These mounds range in height from a few feet to 60 feet.

The sandstone mounds in the southern part of the county, ranging in height from 15 to 175 feet, add a picturesque appearance to the otherwise flat sand plain. Mosquito Mound, south of Bancroft, trends N. $80^{\circ} \mathrm{W}$., is about 0.9 mile in length and 0.2 mile in width, and protrudes about 175 feet above the sand plain (pl. 1). The elongated hill has a steep face to the west and a gentle slope to the east. This form may have been caused by the abrasion of glacial ice.

The part of Mosquito Mound that is buried in outwash has a slope nearly as steep as that above the ground. Well Pt-21/8/25-300, 500 feet southwest of this mound, penetrated 90 feet of sand and gravel but no sandstone.

Most of the mounds consist of poorly cemented sandstone capped by beds of well-cemented sandstone. The narrow sandstone ridges in sec. 32 , T. 21 N., R. 8 E., are the exception; there the sandstone is well cemented 10 to 30 feet on either side of northeast-trending vertical joints.

Near Stevens Point where remnants of sandstone overlie granite or gneiss, several feet of light-colored clay underlie the sandstone. The clay contains grains of quartz and grades downward into decomposed granite or gneiss.

Although the sandstone in the southern part of the county is a potential source of water, no wells as of 1964 have been developed in it. Almost all wells drilled in the area were terminated in the over- 
lying drift, and the few wells that did pentrate sandstone were developed in the drift. The importance of the sandstone as a potential source of water is considered minor not only because large supplies of ground water can be obtained from the overlying drift, but also because the sandstone is less permeable than the drift and would not yield large supplies of water.

\section{DEPOSITS OF GLACIAL DRIFT}

During the Pleistocene Epoch, climatic changes brought about the accumulation of large masses of snow and ice in the northern part of North America. As the accumulation continued, the ice masses, called continental glaciers, expanded horizontally. The ice fronts became irregular as the rate and direction of movement of the ice varied because of changes in topography and climatic conditions.

Portage County was partly covered by at least one large continental ice sheet during the Wisconsin Glaciation (Thwaites, 1943). The Green Bay lobe of that ice sheet extended across at least the eastern half of the county. Glacial striations and the lineation of drumlins indicate that the ice sheets advanced toward the south and toward the west. Minor advances and retreates of the ice front, called stades, occurred during the glaciation. Ice-transported sediments were dumped near the forward edge of the ice sheet. The limits of these deposits, called moraines, are shown on figure 8 .

The Wisconsin Glaciation in Wisconsin has been subdivided (Thwaites, 1946, p. 80, Leverett, 1932, p. 22) into the Iowan, Tazewell, Cary, and Valders Stades. The Border Drift of Hole (1943) (Weidman, 1907; Leverett, 1929) in the northwestern part of Portage County and the Arnott moraine in the central part are probably early Cary or pre-Cary in age, and the drift exposed in the eastern half of the county is of Cary age (pl. 1 ; fig. 8 ).

Drift consists of unsorted deposits (till), and sorted and stratified deposits (outwash and kames). Because the depoits of till are commonly quite sandy, it is difficult and sometimes impossible to determine the subsurface contacts between till and outwash.

\section{ARNOTT MORAINE}

The Arnott moraine in central Portage County, which marks the westward advance of an early ice sheet (pl. 1; fig. 8), is a north-southtrending irregular ridge surrounded by outwash; it is approximately half a mile wide and rises 50 to 80 feet above the surrounding outwash plain. The Arnott moraine has gaps cut by glacial streams draining westward from the Cary ice sheet (pl. 1), and its northern extension has been overlapped by the Outer moraine. 


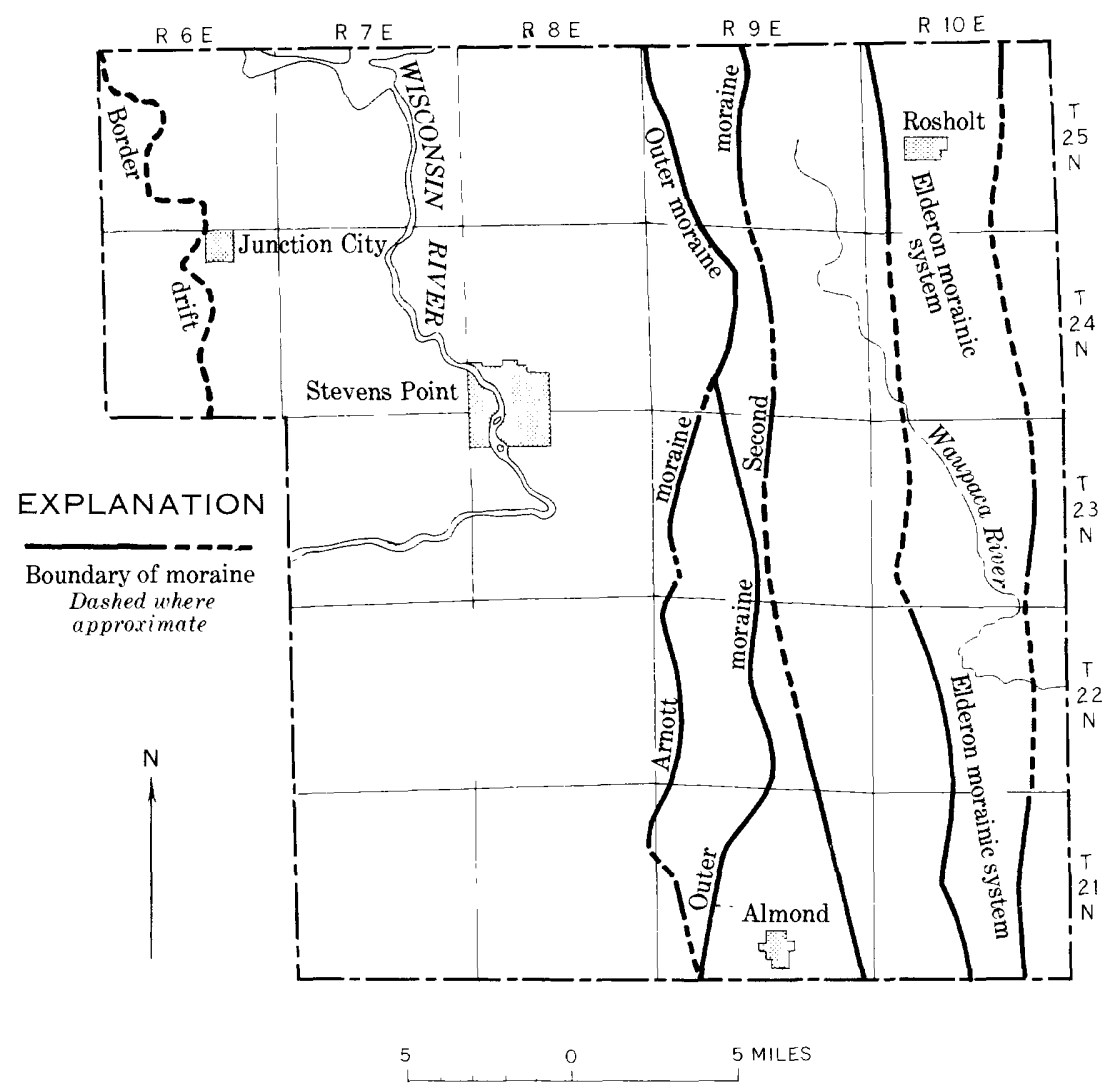

FIgURe 8.-Map of Portage County showing location of moraines. Base from Wisconsin Highway Commission road map.

Leverett (1932, p. 22-23) correlated the drift of the Arnott moraine as Illinoian. This correlation is uncertain because of the great distance between Portage County and the type locality. Thwaites (1946, p. 78) states that "the Arnott moraine, which is much weathered and considerably eroded, is not unlikely of Illinoian age." The drift of the Arnott moraine is definitely older than the Cary Drift of the Outer moraine to the east inasmuch as the Arnott moraine is overlapped by the Outer moraine near Stockton (pl. 1; fig. 8).

The Arnott moraine consists of sandy and stony drift mainly unsorted till, ranging in particle size from clay to boulders. The gravel and larger size rocks are predominantly granite, felsite, sandstone, quartzite, and gneiss, and a small parcentage are chert and dolomite. The large proportion of quartz sand in the drift is attributed to the glacial erosion of the sandstone bedrock and unconsolidated alluvium to the east and northeast. 
Because the till consists of unsorted material ranging in size from clay to boulders, the pore spaces between the larger particles are filled by the smaller particles and the resulting effective porosity may be low. The water-yielding characteristics of the till are not known, but supplies adequate for domestic use have been obtained from shallow wells.

BORDER DRIFT OF HOLE (1943)

The Border Drift of Hole (1943) in northwestern Portage County is a thin, heterogeneous deposit of clay, silt, sand, and gravel (pl. 1; fig. 8). The few large erratics, red felsite, Keweenawan conglomerate, basalt, and rhyolite, may have been derived from the Lake Superior region. The greatest number of rocks in the drift consist of residual fragments of the underlying granite, gneiss, schist, and quartzite.

The age of the Border Drift of Hole (1943) long has been assumed to be pre-Wisconsin. Chamberiin (1882, p. 717-723), Weidman (1907, p. $447-450)$, and Leverett $(1929$, pl. 1) correlated the drift as preWisconsin on the basis of the extent of erosion and on the subdued topography of areas of thick drift in states to the south. Thwaites (1943, p. 119-120) and Hole (1943, p. 509-519) recognized the immaturity of the soils of the area and the unaltered condition of many mineral particles in the drift. Bedrock controls the topography in this area of thin drift. Thwaites concluded that the Border Drift of Hole is of Wisconsin age and is not much older than the Cary Drift to the east.

The Border Drift of Hole in northwestern Portage County has an average thickness of about 4 feet. The drift was deposited locally as ground moraine without the ridges associated with terminal or recessional moraines. The drift is thickest along the western boundary of the county and thins to the east. The absence of till in the Wisconsin River valley may be due to its removal by erosion, or the area may never have been glaciated. The quartzite hills near Wausau, in Marathon County, may have prevented the glacier from descending the Wisconsin River valley.

Thin sand and gravel deposits in the unconsolidated Border Drift of Hole constitute a source of ground water in northwestern Portgage County. Supplies of water adequate for domestic and stock use are obtained from shallow driven and drilled wells that tap the thin drift and the underlying crystalline rock. In the Junction City area, the drift is too thin to be a large source of supply. 
The major glacial features, now in evidence in Portage County, were formed during the Cary Stade and are related to the Green Bay lobe of the Wisconsin ice sheet. The advancing ice sheet picked up material, generally granite, schist, gneiss, and quartzite, and, also, a large amount of the friable Cambrian sandstone and unconsolidated sand, from previous glacial deposits and from local bedrock. Limestone, dolomite, and shale were picked up farther east. The waning glacier dropped this load of heterogeneous, unsorted material in the form of moraines (pl. 1; fig. 8). The melt water from the ice sheet reworked parts of the till and deposited sediment in the form of kames, outwash plains, fans, and deltas.

The Outer moraine marks the most westerly known advance of the Cary ice sheet in Portage County (fig. 8). The moraine is a ridge of till, more or less broken by drainage outlets and partially buried by later outwash deposits. Kettles, depressions made by the melting of ice masses buried in the moraine, contribute to the irregular shape of the ridges.

Much of the unconsolidated deposits east of the Cary moraine consist of ice-contact deposits, outwash, and till, and are shown on plate 1 as outwash, ice-contact, and moraine deposits. Ice-contact deposits are mostly glaciofluvial in origin and were deposited between and on stagnant ice masses during the later stages of glacial wastage, when isolated blocks and tongues of ice occurred in low places and valleys. The shape and distribution of the former ice masses are reflected in the form of the ice-contact deposits and in the shape of kettles and kettle lakes. Ice-contact deposits form kames, kame terraces, kame deltas, and ice-fracture fillings. Flat surfaces, such as kame terraces, mark areas that were free of ice when the uppermost strata were deposited.

The Second moraine and the Elderon morainic system (fig. 8) are recessional moraines formed when the rate of melting of the Cary ice sheet balanced the rate of forward motion. These moraines are roughly parallel to the Outer moraine, but the Second moraine coalesces with the Outer moraine near Polonia and diverges to the north and south.

The Second moraine consists of drift having the same general composition as the Outer moraine. The sand-size fraction predominates over the clay-, silt-, gravel-, and boulder-size fractions. The till is interspersed with outwash and kame deposits. Wells tapping the till deposits obtain sufficient water for domestic and stock use. Large yields have been obtained from wells that penetrate lenses or channels of sorted sands and gravels in the till.

$778-0290-65-3$ 
The Elderon morainic system consists of a series of north-south trending ridges of drift east of the Second moraine. The ridges have been broken into widely separated sections by numerous drainage channels. The composition of the till differs from that of the Outer and Second moraines in that it contains a greater percentage of carbonate rock material and material of clay and silt size. The largest percentage of material is of sand size. The till yields small quantities of water to drilled wells.

Glacial Drainage.-The courses taken by melt-water drainage changed as deglaciation progressed. In the early stages of ice wastage, melt water flowed westward from the Outer moraine, cutting channels through the Arnott moraine and depositing sand and gravel as an outwash plain covering the central and southwestern parts of the county. The water drained westward to the valley of the Wisconsin River and to glacial Lake Wisconsin. As the ice continued to waste in the area of the Second moraine, melt water deposited sand and gravel between this moraine and the Outer moraine, forming the Almond plain, and eventually cut channels through the Outer moraine. Melt water then deposited sand and gravel over the outwash plain west of the Outer moraine. Later, as the eastward wastage of the ice continued, melt water escaped southeastward, draining into glacial Lake Oshkosh in Waushara and Winnebago Counties.

Numerous terraces of outwash were formed along the Waupaca and Tomorrow Rivers by changes in the grade of the melt-water streams. The changes in grade may have been caused by the opening of new drainage outlets through wastage of the glacier, by the melting of obstructing ice blocks, by the change of stream regimen from depositing to eroding, or by a combination of these causes. Four prominent terraces may be seen at Nelsonville and at Amherst.

The ice front receded from the area by downwastage. Blocks of stagnant ice in the valleys were covered by drift and remained long after the hills were exposed. Glacial melt water transported and deposited sand and gravel between and over much of the stagnant ice in the low-lying places. The subsequent melting of blocks of ice left chains of kettles and lakes in several of the valleys. Examples of such chains of lakes are Emily, Julia, and Ell Lakes near Amherst Junction and Washburn and Bass Lakes near Almond, where blocks of ice were buried by thick till. Isolated kettles and lakes, such as Thamar, Patterson, and Silver Lakes, occur as depressions in the moraines.

\section{OUTWASH DEPOSITS}

The most important sources of ground water in the county are thick and extensive deposits of well-sorted sand and gravel which form 
gently sloping outwash plains, pitted outwash terraces, and areas where ice-contact features such as kames are prominent. Much of the sand and gravel is well sorted, but may contain some silt and clay. In a few areas, thin layers of clay, silt, or fossil soil are interbedded in the sand and gravel. Till overlies outwash or is interbedded in outwash in many areas in the eastern part of the county.

The outwash plain in central and southwestern Portage County, commonly called the central sand plain or Bancroft plain, extends over about 302 square miles and consists of deposits of sand and gravel. The sand and gravel is very well sorted and contains only small amounts of silt and clay. The thickness of the out wash averages about 100 feet, ranging from a few feet in the Hay Meadow Creek area to about 250 feet near the Outer moraine (fig. 9). Several isolated ridges or mounds of sandstone in the Bancroft area protrude above the outwash and locally reduce its thickness. The variation in thickness of

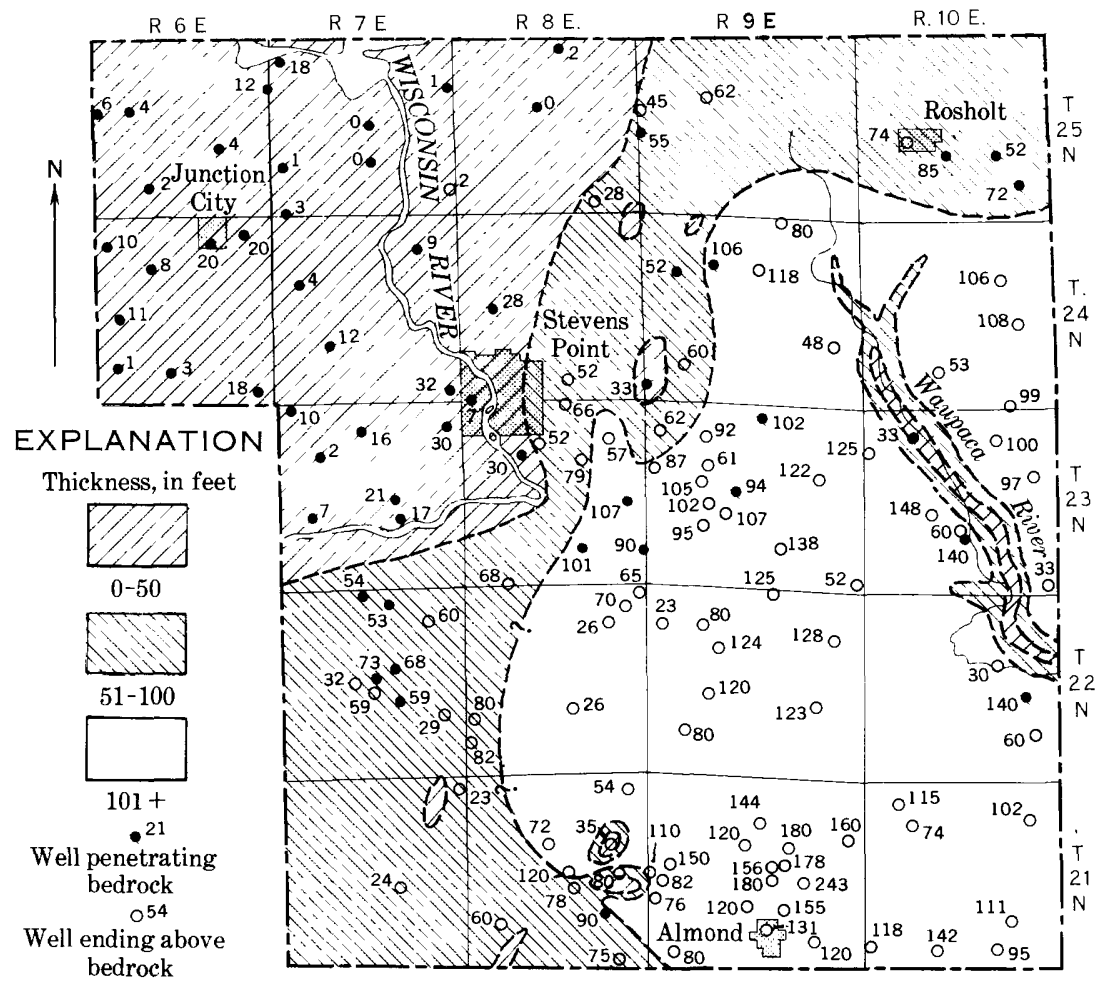

Number is thickness, in feet 5 MILES

FrgURE 9.-Map of Portage County showing approximate thickness of unconsolidated deposits. Base from Wisconsin Highway Commission road map. 
the outwash deposits and their contact with underlying crystalline rock and sandstone is shown in cross-sectional view, plate $1 A-A^{\prime}$.

The Arnott plain between the Outer and Second moraines in the southern part of the county contains thick deposits of sand and gravel (pl. 1; fig. 9) that yield large supplies of water to wells. Although no well penetrates the full thickness of the deposits, many wells penetrate at least 150 feet of sand and gravel. A sample log of well Pt21/9/22-265 (fig. 10) shows the well-sorted character of the sand and gravel. This $\log$ is representative of the logs of wells in the Almond area and of many of the wells in the sand plain.

The land surface of the Arnott plain is characterized by a high-level terrace of outwash containing numerous pits and a low-level terrace. The Outer moraine acted as a dam and a temporary reservoir for the large volumes of sediments carried by the melt water. As drainage outlets were opened to the west in the moraine, the gradient of the outwash streams was steepened and a new level of drainage was formed that extended westward to the central sand plain.

\begin{tabular}{|c|c|c|c|}
\hline $\begin{array}{l}\text { Depth, } \\
\text { in feet }\end{array}$ & $\begin{array}{c}\text { Thickness, } \\
\text { in feet }\end{array}$ & $\begin{array}{c}\begin{array}{c}\text { Graphic } \\
\log \end{array} \\
\end{array}$ & Description \\
\hline $0-10$ & 10 & $\because$ & Sand, medium, light-brown \\
\hline $10-15$ & 5 & gisiaid & Gravel, fine, sandy, light brown, some dolomite \\
\hline $15-45$ & 30 & & Sand, medium to very coarse, pink-gray \\
\hline $45-65$ & 20 & & Sand, medium to very coarse, few pebbles, light-brown-gray \\
\hline $65-85$ & 20 & & Sand, fine to coarse, some fine gravel, pink-gray and light-brown \\
\hline $85-115$ & 30 & & Sand,fine to coarse, dolomitic, few small pebbles, light-brown-gray \\
\hline $115-130$ & 15 & & Sand, very coarse to fine, dolomitic, tan \\
\hline$\frac{\frac{130-132}{32-133}}{\frac{132}{35-135}}$ & $\frac{\frac{2}{1}}{\frac{1}{10}}$ & $\therefore$ & $\begin{array}{l}\text { Gravel, fine, much dolomite, sandy } \\
\text { Clay, pink, dolomitic, Iittle sand } \\
\text { Gravel, fine, much dolomite, some silt } \\
\text { Sand, fine to very coarse, dolomitic, some silt }\end{array}$ \\
\hline $145-165$ & 20 & & Sand, coarse, pink-gray, dolomitic \\
\hline $165-170$ & 5 & & Gravel, fine, pink-gray, much dolomite \\
\hline $170-185$ & 15 & & Sand, fine to coarse, pink-gray, dolomitic \\
\hline $185-205$ & 20 & & Sand, medium, some fine gravel, pink-gray, dolomitic \\
\hline $205-215$ & 10 & 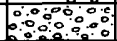 & Gravel, very fine, sandy, pink-gray, dolomitic \\
\hline $215-225$ & 10 & $\because 0 \%$ & Sand, fine to coarse, few pebbles, dolomitic, $\tan$ \\
\hline $225-237$ & 12 & $\begin{array}{ll}0: 00000 \\
0: 00000 \\
0.000\end{array}$ & Gravel, much dolomite, sandy \\
\hline
\end{tabular}

Well owner: James Burns. Drilled: 1957, by M. D. Bowen Co. Aquifer: drift. Use: irrigation. Samples examined by: The Wisconsin Geological and Natural History Survey. Total depth: 243 feet.

Figdre 10.- Sample $\log$ of well Pt-21/9/22-265, Portage County. 
In northwestern Portage County, outwash deposits are thin; and it is impractical, if not impossible, to develop large supplies of ground water. In many places where outwash deposits occur at the surface (pl. 1), the sorted material may be unsaturated or may contain only a thin zone of saturation.

\section{POSTGLACIAL DEPOSITS}

\section{ALLUVIUM}

The material mapped as alluvium on figure 8 consists of deposits of organic and inorganic materials in marshes or drained marshes and valley alluvium. Marsh deposits consist of dark-colored organic clay, silt, or sand and, in many places, peat. The peat deposits do not exceed 25 feet, and are generally less than 5 feet, in thickness. Deposits of peat ranging from a few inches to 5 feet in thickness cover extensive areas in the southwestern and northern parts of the county. Locally, marsh deposits occur in kettles and along the margins of lakes and streams.

The valley alluvium consists of lenticular deposits of well-sorted silt, sand, and gravel that range in thickness from a few feet in the smaller stream valleys to as much as 60 feet in the Wisconsin River valley. The valley alluvium is similar to the outwash deposits and is hydrologically interconnected. The primary difference between the valley alluvium and the adjacent outwash deposits is that the alluvium has a lower topographic position.

\section{DUNE SAND}

Sand dunes, anchored by vegetation, are common to the outwash plain area. Most of the dunes are small and were formed during and immediately after the glaciofluvial deposition of the outwash. The east-west elongation of the dunes plus the east direction of dip of the foreset beds indicate that westerly winds were prevalent during the formation of the dunes. Peat has formed between the dunes. A few dunes are of the recent blow-out type where sand was blown out of holes in the peat that covered the outwash. The holes in the peat cover were probably due to peat and grass fires.

The sand dunes are mapped as part of the outwash sand and gravel deposits. Although the dunes are above the saturated zone, they are hydrologically significant because the sand is well sorted and transmits water rapidly downward to the underlying aquifer.

\section{GROUND-WATER PROVINCES}

Ground-water conditions have been shown to be far from uniform throughout Portage County; not only do they differ from area to area, 
they also vary with depth and time. Nevertheless, ground water occurs in several areas under generally similar geologic and hydrologic conditions. Areas in which the character of the rocks, the availability and quality of the water, the topography, and the surface drainage are similar, have for convenience here been termed "ground-water provinces" and are named the "sand-plain province," the "drift province," and the "drift-crystalline rock province." The extent of these provinces is shown in figure 20 . The indicated boundaries are approximate and do not represent the limits of aquifers.

\section{DRIFT-CRYSTALLINE ROCK PROVINCE}

The water resources of the drift-crystalline rock province, in the northwestern part of the county, consists of ground water in thin aquifers of outwash, alluvium, and fractured crystalline rock and of surface water in streams and reservoirs. All streams drain to the Wisconsin River.

The aquifers yield only small amounts of ground water to wells and to streams. Most of the wells are less than 50 feet in depth and obtain water from saturated outwash and alluvium. A few wells drilled to depths ranging from 50 to 150 feet tap fractures or weathered parts of crystalline rock; these wells yield small amounts of water.

Residents of Junction City, the only large community in the province, have difficulties in developing adequate supplies of potable water. Crystalline rock is very near the surface and sand and gravel deposits are thin and very limited in extent. Objectionable quantities of iron in ground water are reported for many of the wells, and pollution is a recurring problem. The village has neither a public water supply nor a sewage-treatment system.

The deposits of saturated sand and gravel that are nearest to Junction City occur along Mill creek and near the Wisconsin and Little Eau Pleine Rivers. Because few wells tap these deposits, test drilling would be necessary to determine their capabilities as sources for water supply.

\section{SAND-PLAIN PROVINCE}

The sand-plain province consists of a thick and extensive aquifer of outwash sand and gravel and is drained by the Plover and Little Plover Rivers and the Hay Meadow Creek in the north and by Buena Vista, Fourmile, and Tenmile Creeks, connected to a system of drainage ditches, in the south. All the water drains to the Wisconsin River. The ground-water divide between the Wisconsin River basin and the Waupaca and Little Wolf River basins (fig. 5) is the eastern limit of the province. 
The characteristics of the aquifer are very uniform over large distances. The deposits consist of well-sorted sand and some gravel and small amounts of silt and clay. The thickness ranges from a few feet to about 250 feet and averages about 100 feet.

The sand-plain province is capable of supplying large quantities of ground water to wells, except possibly in the Hay Meadow Creek and Plover River areas where the sand and gravel is less than 50 feet thick. The areas that are especially promising for future development are near Almond, Bancroft, Coddington, and Plover and in the Grant Township.

Large-capacity wells, drilled by percussion or reverse-rotary methods, range in depth from about 60 to about 250 feet and average about 110 feet. The reported average yield of 52 irrigation wells in the province is about $1,100 \mathrm{gpm}$ per well. About 40 pits are pumped for irrigation at rates ranging from 100 to $800 \mathrm{gpm}$.

\section{DRIFT PROVINCE}

The drift province consists of thick aquifers of sandy till, outwash, and ice-contact deposits. It is drained by the Waupaca and Little Wolf Rivers. The ground-water divide between the Waupaca and Little Wolf River basins and the Wisconsin River is the western limit of the province (fig. 5).

The characteristics of the aquifers change considerably over short distances. Small supplies of water may be developed from sandy till and alluvium, and large supplies may be developed from outwash and ice-contact deposits. The thickness of the deposits ranges from a few feet to about 350 feet.

In the drift province, small-capacity wells generally are drilled or driven, and most wells penetrate only 10 to 50 feet of the saturated sediments. These wells generally are equipped with 2 to 6 feet of screen. Their yield ranges from a few gallons per hour for wells in till to as much as $50 \mathrm{gpm}$ for wells in outwash.

Large-capacity wells, drilled by percussion or reverse-rotary methods, penetrate greater thicknesses of the aquifers. Such wells are developed generally in outwash and kame deposits. The reported average yield of 11 irrigation wells is about $500 \mathrm{gpm}$.

The best areas for development of large ground-water supplies in the drift province are in the sand and gravel deposits in the Waupaca River valley, in the Radley and Murry Creek areas in the southeastern part of the county, and in the Rosholt area in the northeastern part of the county. 


\section{HYDRAULIC PROPERTIES OF AQUIFERS}

The ability of an aquifer to store water and to transmit water to wells, streams, and lakes is dependent on the hydraulic properties of the aquifer. The principal hydraulic properties of aquifers are porosity, specific retention, specific yield, and coefficients of storage, permeability, and transmissibility.

"Porosity" is the ratio of the volume of the void spaces to the total volume of soil or rock. When all voids are filled with water, porosity represents the upper linit of saturation.

"Specific retention" of a soil or rock is the percentage of its volume that is occupied by water that will not drain from it by gravity and will not be yielded to wells. The terms "soil-moisture capacity" or "field capacity" express the same relationship as does "specific retention."

"Specific yield" of water from soil or rock is the ratio of the volume of water that will drain by gravity to the total volume of the soil or rock. The specific yield approximates the percentage of water that a given volume of rock will yield to wells. Specific yield is a function of time and requires prolonged periods of no recharge or pumping before the soil or rock is drained by gravity.

The "coefficient of transmissibility" may be expressed as the rate of flow of water, at the prevailing water temperature, in gallons per day, through a vertical strip of the aquifer 1 foot wide extending the full saturated height of the aquifer under a hydraulic gradient of 100 percent.

The "coefficient of permeability" is defined as the rate of flow of water, in gallons per day, through a cross-sectional area of 1 square foot under a unit hydraulic gradient and at a water temperature of $60^{\circ} \mathbf{F}$.

The "coefficient of storage" of an aquifer is the volume of water released from or taken into storage per unit surface area of the aquifer per unit change in the component of head normal to that surface.

\section{SPECIFIC YIELD}

Specific yield, specific retention, and porosity were determined by laboratory methods for disturbed samples of sand and gravel collected at 5- to 15-foot intervals of depth in well Pt-23/9/18-362. The laboratory tests were made by the Hydrologic Laboratory of the U.S. Geological Survey, Denver, Colo. The results are given in table 2.

Table 2 shows that the specific yield ranged from about 31 percent at the 0 - to 5-foot depth to about 21 percent at the 35- to 40 -foot depth and average about 27 percent. Specific yields above 27 percent were 
determined for samples obtained at the depth intervals of 0 to 25 feet and 65 to 90 feet.

Specific yield obtained by labolatory methods may be termed "potential specific yield" because a considerably greater length of time was allowed for draining in the laboratory than is generally attained under field conditions.

C. B. Tanner (written commun., 1957) determined that the Plainfield, Coloma, and related sandy soils, which occur over much of the sand-plain province, have a porosity that ranges from 32 to 38 percent and a field-moist ure capacity that ranges from 8 to 13 percent. On the basis of these figures, the specific yield of the soil ranges from 19 to 30 percent and is probably about 24 percent.

The estimated field specific capacity for the sand and gravel aquifer in the sand-plain province is about 22 percent and is about 5 percent greater than the laboratory specific yield determined at well Pt-23/9/18-362 (table 2).

The fairly high specific yield of the sandy soil at the surface of the sand-plain province and the homogeneity of the sand and gravel aquifer as shown by sample $\log \mathrm{s}$ indicate that recharge from precipitation should pass readily from the surface to the zone of saturation.

TABle 2.-Summary of laboratory analysis of samples from uell Pt-2.3/9/18-362. Little Plover River basin, Wisconsin

\begin{tabular}{|c|c|c|c|c|c|}
\hline \multirow{2}{*}{ Laboratory sample } & \multicolumn{2}{|c|}{ Depth (feet) } & \multirow{2}{*}{$\begin{array}{l}\text { Specific } \\
\text { retention } \\
\text { (percent) }\end{array}$} & \multirow{2}{*}{$\begin{array}{c}\text { Specific } \\
\text { yield } \\
\text { (percent) }\end{array}$} & \multirow{2}{*}{$\begin{array}{l}\text { Porosity } \\
\text { (percent) }\end{array}$} \\
\hline & From- & To- & & & \\
\hline $\begin{array}{r}\text { 60WIS } 38 \\
\quad 39 \\
40 \\
41-2 \\
43 \\
44 \\
45 \\
46\end{array}$ & \multirow[t]{2}{*}{$\begin{array}{r}0 \\
5 \\
15 \\
25 \\
35 \\
40 \\
55 \\
65 \\
80\end{array}$} & \multirow[t]{2}{*}{$\begin{array}{r}5 \\
15 \\
25 \\
35 \\
40 \\
55 \\
65 \\
80 \\
90\end{array}$} & $\begin{array}{l}5.2 \\
4.1 \\
3.4 \\
4.4 \\
7.0 \\
5.0 \\
6.2 \\
7.0 \\
5.9\end{array}$ & $\begin{array}{l}30.5 \\
29.1 \\
29.4 \\
25.2 \\
20.7 \\
24.4 \\
24.8 \\
28.3 \\
29.7\end{array}$ & $\begin{array}{l}35.7 \\
33.2 \\
32.8 \\
29.6 \\
27.7 \\
29.4 \\
31.0 \\
35.3 \\
35.6\end{array}$ \\
\hline A verage & & & 5.4 & 26.9 & 32.3 \\
\hline
\end{tabular}

PUMPING TEST DETERMINATIONS OF AQUIFER CHARACTERISTICS

The withdrawal of water from an aquifer creates a depression of the water level in the vicinity of the point of withdrawal. The depression formed by a pumping well has the approximate form of an inverted cone and is referred to as the "cone of depression." The size, shape, and rate of growth of the cone of depression depend on several factors, including (1) the rate of pumping, (2) the transmissibility and storage capacity of the aquifer, (3) the decrease in nat ural discharge due to the lowering of the water level, and (4) the increase in recharge resulting from the lowering of the water level. 
Pumping tests were made to determine the coefficients of transmissibility and storage of the unconsolidated deposits of sand and gravel in the Almond and Plover areas of the sand-plain province. The results of the tests, which were obtained by use of the nonequilibrium equation, as described by Theis (1935, p. 519-52t) and by the use of Boulton's integral equation as described by Stallman (1961, p. 24 29 ), are summarized in table 3 .

The methods used to determine the coefficients are based on the assumptions that the aquifer is of uniform thickness, of infinite areal extent, and is homogeneous and isotropic (that is, that it transmits water with equal ease in all directions). It is assumed also that there is no recharge to the formation and no discharge other than that from the pumping well and that water may enter the well throughout the full thickness of the aquifer. Although none of these conditions is fully met in nature, pumping tests are of value if discretion is used in their interpretation and if the prevailing geologic conditions are reasonably understood.

TABLE 3.-Hydraulic characteristics determined from pumping tests

\begin{tabular}{|c|c|c|c|c|c|c|c|}
\hline $\begin{array}{l}\text { Punped well } \\
\text { Pt- }\end{array}$ & Observation wells & $\begin{array}{l}\text { Thick- } \\
\text { ness of } \\
\text { aquifer } \\
\text { (feet) }\end{array}$ & $\begin{array}{l}\text { Length } \\
\text { of test } \\
\text { (hours) }\end{array}$ & $\begin{array}{c}\text { Specific } \\
\text { capacity } \\
\text { (gpm } \\
\text { per ft) }\end{array}$ & $\begin{array}{c}\text { Coeffi- } \\
\text { cient of } \\
\text { transmis- } \\
\text { sibility } \\
\text { (gpd per } \\
\text { ft) }\end{array}$ & $\begin{array}{l}\text { Coeffi- } \\
\text { cient of } \\
\text { storage }\end{array}$ & $\begin{array}{l}\text { Field co- } \\
\text { efficient } \\
\text { of per- } \\
\text { meability } \\
\text { (gpd per } \\
\text { sq ft) }\end{array}$ \\
\hline $\begin{array}{l}21 / 9 / 15-28 \ldots \ldots . . .- \\
21 / 9 / 9-60 \\
23 / 9 / 18-279 \\
\end{array}$ & $\begin{array}{l}\mathrm{Pt}-21 / 9 / 15-209 \\
\text { Pt-21/9/9-89. } \\
\text { Array of } 21 \text { observation }\end{array}$ & $\begin{array}{rl}1 & 140 \\
1 & 150 \\
& 80\end{array}$ & $\begin{array}{l}12 \\
12 \\
74\end{array}$ & $\begin{array}{l}21 \\
30 \\
53\end{array}$ & $\begin{array}{l}270,000 \\
330,000 \\
140,000\end{array}$ & $\begin{array}{r}0.15 \\
.14 \\
.15\end{array}$ & $\begin{array}{l}1,900 \\
2,200 \\
1,750\end{array}$ \\
\hline $\begin{array}{c}24 / 8 / 34-57 \text { and } \\
24 / 8 / 34-111\end{array}$ & $\begin{array}{l}\text { Array of } 26 \text { observation } \\
\text { wells. }\end{array}$ & 160 & 24 & & 100,000 & .20 & 1,700 \\
\hline
\end{tabular}

1 Estimated.

The tests of wells Pt-21/9/15-28 and Pt-21/9/9-60 in the Almond area gave similar results (table 3 ). The wells were similarly constructed and tapped about equal thicknesses of the sand and gravel aquifer, but neither well completely penetrated the full thickness of the aquifer. The aquifer was considered infinite in areal extent because both recharge and barrier boundaries were more than a mile from either well. The tests were conducted for 12 hours using shallow drive-point wells for observation of water-level changes. The coefficients of transmissibility and storage averaged about 300,000 gpd (gallons per day) per $\mathrm{ft}$ and 0.15 , respectively. The field coefficient of permeability averaged about 2,000 gpd per sq $\mathrm{ft}$ of aquifer.

The results of the test of well Pt-23/9/18-279 in the Plover area, using an array of 21 observation wells, gave coefficients of transmissibility and storage that averaged about 140,000 gpd per ft and 0.15 , respectively (table 3 ). The field coefficient of permeability 
averaged about $1,750 \mathrm{gpd}$ per sq ft of aquifer. Well $\mathrm{Pt}-23 / 9 / 18-279$ was drilled with a reverse-rotary drill to the full thickness of the aquifer, equipped with 20 feet of shutter screen, and gravel walled. The observation wells, equipped with 2 feet of screen, were driven to depths ranging from 21 to 28 feet.

In unconfined aquifers, such as those in Portage County, the coefficient of storage is practically equal to the specific yield of an aquifer. The average coefficient of storage determined by the pumping tests, 0.15 , is considered to be the minimum specific yield because the length of time of pumping was not adequate for drainage of the dewatered materials. When the water table recedes around the pumped well, the less permeable layers of silt and sand yield water much more slowly than do the more permeable layers of sand and gravel. Similarly, when the water table rises, the less permeable layers are saturated less rapidly than are the layers of sand and gravel. The potential specific yield, 0.27 , as determined in the laboratory, is considered to be the maximum specific yield and represents draining after a prolonged period of pumping or a sustained drought.

The field specific yield, or "gravity yield" as proposed by Rasmussen and Andreasen (1959), is the ratio of the volume of drained water released during a period of ground-water recession to the total volume of rock that was saturated or partially saturated. The average field specific yield of the sand and gravel aquifer in the sand-plain province is probably about 0.2 .

The pumping tests of three wells in the Almond and Plover areas have given hydraulic coefficients for only a very small part of the sand and gravel aquifer in the sand-plain province. Nerertheless, general geologic information, $\log _{\mathrm{s}}$ of wells, and data on the specific capacity of wells indicate that the aquifer characteristics determined by the tests are representative of the aquifer in much of the sand-plain province. Logs of wells in the province show that the sand and gravel deposits extend over the entire area and contain only a few lenses or interbedded layers of silt and silty clay. The arerages of the specific capacities reported for wells in the sand-plain province (table 4) agree generally with the specific capacities determined by the pumping tests.

\section{EFFECTS OF PUMPING ON WATER LFVELS}

The results of the pumping tests may be used in a general way to predict the rate and amount of lowering of water levels to be expected at various times from a well whose rates of discharge are known. In the sand-plain province the average thickness of the sand and gravel aquifer is about 100 feet. On the basis of a coefficient of transmissibility of 200,000 gpd per $\mathrm{ft}$, a coefficient of storage of 0.15 , arbitrary 
pumping rates of 500 and $1,000 \mathrm{gpm}$, and arbitrary periods of 30 and 90 days of pumping, substitution may be made in the Theis nonequilibrium formula to obtain the theoretical effects of pumping shown in figure 11. By comparing the curves representing pumping at rates of 500 and $1,000 \mathrm{gpm}$, it is apparent that the drawdown is directly proportional to the discharge. The drawdown caused by a well pumping $2,000 \mathrm{gpm}$ would be about twice that of a well pumping $1,000 \mathrm{gpm}$.

To prevent excessive declines in water levels because of interference between pumping wells, the wells should be spaced an adequate distance apart. An adequate spacing between wells pumping $500 \mathrm{gpm}$ for 30 consecutive days is probably about 500 feet, and an adequate spacing between wells pumping $1,000 \mathrm{gpm}$ for 90 consecutive days is probably about 2,500 feet. Estimates of the decline in water level at any well can be made by adding together the drawdown effects caused by surrounding pumping wells. These estimates will be larger than the actual decline in water level because the effects of recharge were not considered in preparing figure 11.

Inasmuch as the graph shown in figure 11 is made on the assumption that the aquifer is infinite in areal extent and homogeneous in character, it does not take into consideration the effects of hydrologic boundaries or drainage effects. Pumping of wells near boundaries, such as streams and drainage ditches, will increase the overall yield of the

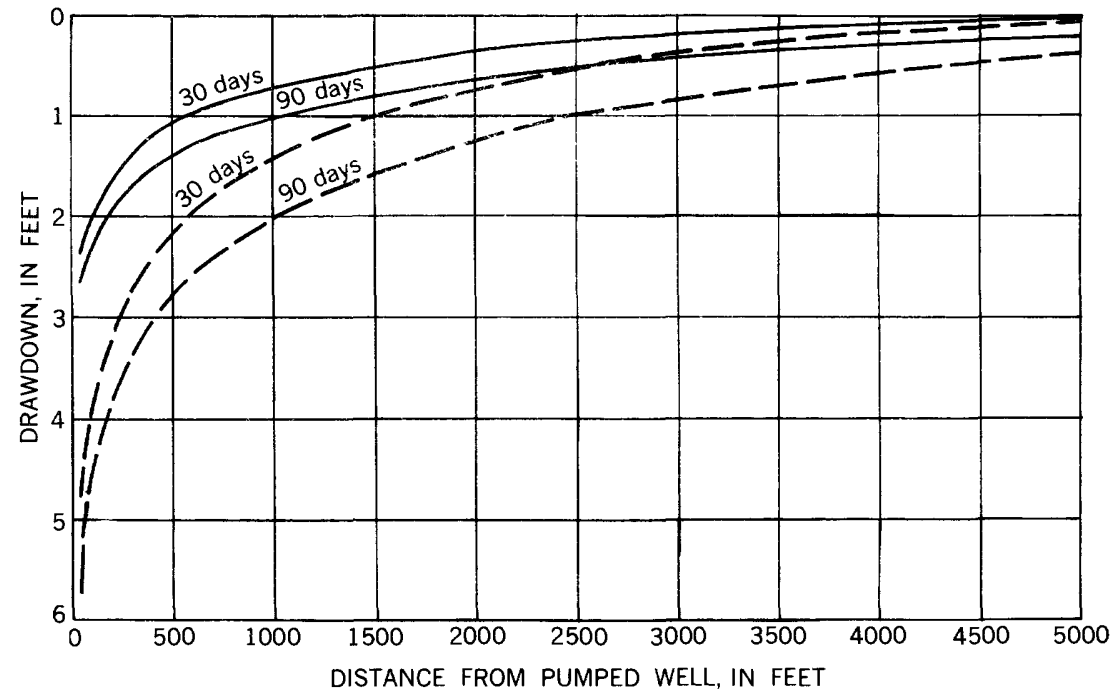

FIgURE 11.-Theoretical distance-drawdown relation for high-capacity wells tapping the sand and gravel aquifer in the sand-plain province, Portage County. Solid line indicates well pumping $500 \mathrm{gpm}$; dashed line indicates well pumping $1,000 \mathrm{gpm}$. Curves based on coefficient of transmissibility of $200,000 \mathrm{gpd}$ per $\mathrm{ft}$ and coefficient of storage of 0.15 . Time designates length of pumping. 
aquifer by permitting heavier pumping while maintaining the same drawdown in water level. Such pumping near a stream induces recharge to the aquifer and reduces the flow of the streams by a like amount. The yield of a pumping well near boundaries, such as the sandst one ridges and mounds that occur in the area, will decrease or the pumping level will decline. The yield may be satisfactory for a considerable period, then decline rapidly when the expanding cone of depression reaches the boundary. A further explanation of the effects of boundaries is given by Ferris and others (1962).

\section{SPECIFIC CAPACITY OF WELLS}

The specific capacity of a well, or yield per unit of drawdown, is expressed as the number of gallons per minute that a well yields for each foot of drawdown of the water level in the well. Under watertable conditions, this relation is approximately constant only when the drawdown is but a small fraction of the saturated thickness of the aquifer. The specific capacity is a measure of the performance of a well because the drawdown depends also upon the differences in construction and development of the well. However, a comparison of specific capacities is useful in estimating the permeability of aquifers and the relative efficiency of wells. The yields and specific capacities of many of the high-capacity wells in the county are given in tables 4 and 5 .

The highest specific capacities in Portage County are in wells in the sand-plain province (table 4). In the Stevens Point-Bancroft area, the average specific capacity of 51 wells pumped at an average rate of about $1,000 \mathrm{gpm}$ was about $60 \mathrm{gpm}$ per $\mathrm{ft}$ of drawdown. In the Almond area, the average specific capacity of 14 wells was about $35 \mathrm{gpm}$ per $\mathrm{ft}$ of drawdown at an average pumping rate of about 750 gpm (table 4).

In the drift province, the average specific capacity of 11 wells pumped at rates varying from 70 to $900 \mathrm{gpm}$ and averaging about 500 $\mathrm{gpm}$ was about $24 \mathrm{gpm}$ per $\mathrm{ft}$ of drawdown (table 5).

\section{MOVEMENT}

Once water infiltrates to the zone of saturation its direction of movement is lateral and nearly horizontal. Unless intercepted by a discharging well, the water continues its lateral movement until discharged as ground-water runoff to streams, lakes, and marshes, or through evapotranspiration. 
TABLE 4.-Yields and specific capacitics of uclls in the sand-plain protince

\begin{tabular}{c|c|c|c|c|c}
\hline Well Pt- & $\begin{array}{c}\text { Diameter } \\
\text { (inches) }\end{array}$ & $\begin{array}{c}\text { Reported } \\
\text { average } \\
\text { pumping } \\
\text { rate (gpm) }\end{array}$ & $\begin{array}{c}\text { Reported } \\
\text { drawdown } \\
\text { of water } \\
\text { level (feet) }\end{array}$ & $\begin{array}{c}\text { Duration } \\
\text { of test } \\
\text { (liours) }\end{array}$ & $\begin{array}{c}\text { Specific } \\
\text { capacity } \\
\text { (gpm per } \\
\text { ft) }\end{array}$ \\
\hline
\end{tabular}

Stevens Point-Bancroft area

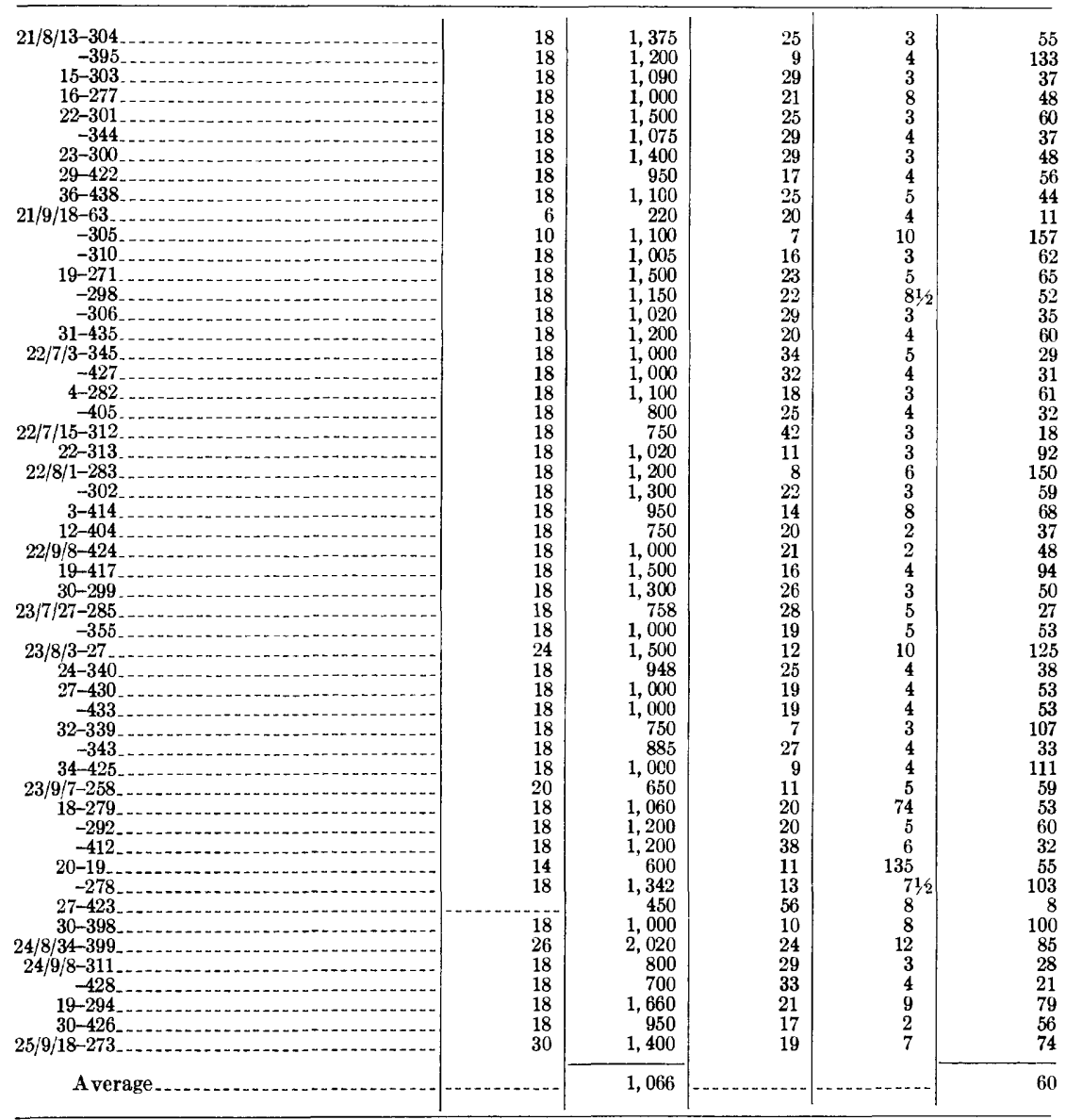

Almond area

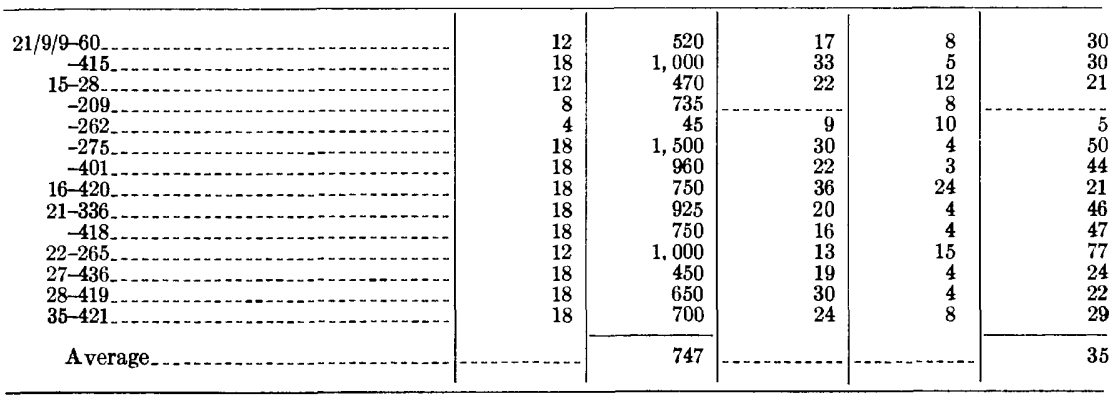


TABLE 5.-Yields and specific capacities of wells in the drift province

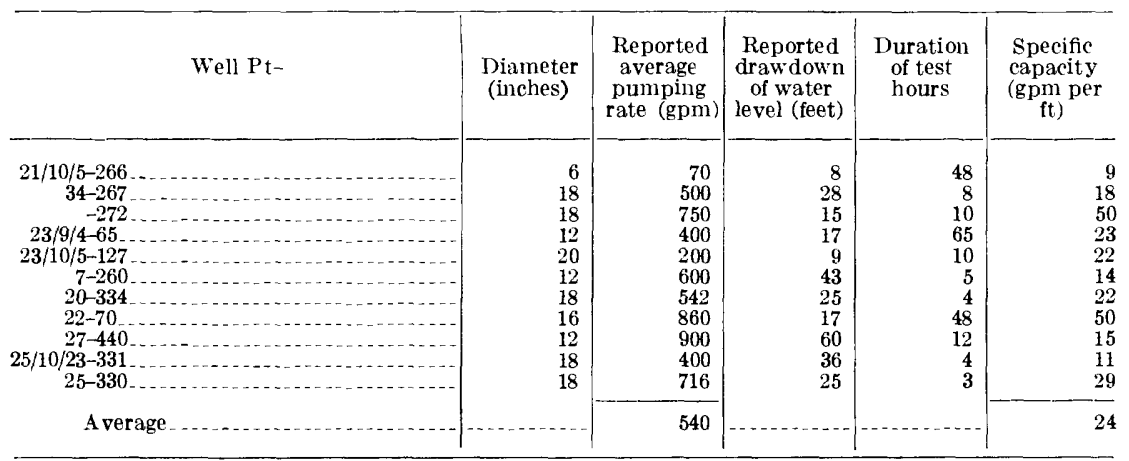

The general pattern of flow of ground water in Portage County can be determined by the shape and slope of the water table. The approximate shape of the water table is shown by water-table contours on plate 2. The contour lines connect points of equal altitude on the water table, determined by measured altitudes of water levels in wells. pits, lakes, and streams as control points. The direction of movement. of ground water is along flow lines; that is, it moves generally at right angles to the water-table contours, where the aquifer is homogeneous and isotropic, and at an acute angle, where the permeability of the aquifer varies considerably.

Streams, lakes, and marshes are the risible part of the ground-water surface in the county. The invisible part occurs a few feet below the land surface in the sand plains and stream valleys and as much as 200 feet below the crests of the moraine hills. The natural gradient of the water table is nearly always toward the streams, lakes, and marshes.

The principal factors that control the shape and slope of the water table are the topography of the land surface and the underlying bedrock, the permeability of the materials through which the water moves, the relative location of areas of recharge and discharge, and the relative rates of recharge and discharge.

In Portage County, the water table has the same general configuration as that of the land surface, except that the water table is more subdued in shape and is constantly fluctuating. Streams are the linear sinks in the water table. A major ground-water divide separates water flowing westward into the Mississippi River via the Wisconsin River and water flowing eastward into Lake Michigan via the Little Wolf and the Waupaca Rivers; this ground-water divide follows generally the crest of the Outer moraine (figs. 5, 8).

The changes in hydraulic gradient are the result of vertical and lateral changes in the permeability of rocks, variations in the thick- 
ness of saturated materials, variations in precipitation that affect the rate of recharge, and variations in the rate of withdrawal of water from wells. The gradient of the water table in the sand-plain province ranges from 3 to 25 feet per mile (pl. 2) and averages about 5 feet per mile. Here the deposits of sand and gravel are thick, well sorted, and very permeable. The 15-25-feet-per-mile gradient of the water table between Bancroft and the Outer moraine is a reflection of the steep slope of the land surface and the westward increase in permeability between the till and the outwash. In the Almond-Arnott areas, between the Outer and Second moraines, the gradient of the water table is almost flat (pl. 2). Here, the saturated material is very thick and has a coefficient of transmissibility of about 300,000 gpd per ft.

In the drift province the water table has a steep gradient (pl. 2), ranging from 5 to 40 feet per mile, because the saturated drift decreases in thickness to the east; the aquifer ranges from permeable deposits of outwash in the valleys and terraces to less permeable sandy till in the moraines.

The rate of movement of ground water is dependent upon the hydraulic gradient and the permeability and thickness of the aquifer. The velocity of ground-water movement under natural conditions is very slow and can be estimated from the equation (see Butler 1957, p. 73) :

$$
v=P I / 7.48 S y
$$

where $v=$ velocity of flow of ground water, in feet per day, $P=$ coefficient of permeability, in gallons per day per square foot,

$I=$ hydraulic gradient, in feet per foot, and $S y=$ specific yield, fraction.

In the sand-plain province west of Bancroft, where the hydraulic gradient is about 5 feet per mile, the ground-water velocity in the sand and gravel aquifer is about 1 foot per day. In the Plover and Stevens Point area, where the gradient is about 20 feet per mile, the velocity of movement through the sand and gravel aquifer is about 3 feet per day. The velocity of movement through the sandy till in the drift province is probably less than a foot a day.

Under heavy pumping conditions, the velocity of ground-water movement in the sand and gravel aquifer in the sand-plain province varies from a few feet per day at a distance of several thousand feet from a pumping well to as much as 1,000 feet per day near a pumping well. 
Buried sandstone ridges of low permeability extend into the highly permeable sand and gravel aquifer in the sand-plain province (pl. 1) and retard and divert the flow of ground water. Such ridges act as ground-water dams retarding the movement of water immediately up the hydraulic gradient. Near Plover, a buried sandstone ridge partially blocks the movement of ground water toward the Wisconsin River and increases effluent seepage into the Little Plover River. In the Bancroft areas, subsurface parts of Mosquito Mound and isolated ridges shown on plate 1 also control the movement of water in the sand and gravel aquifer.

\section{WATER-IEVEL FLUCTUATIONS}

Changes of water levels in wells reflect the changes of water in storage in ground-water reservoirs. The volume of ground water in storage varies with changes in the amounts of recharge and discharge. When recharge exceeds discharge, there is an increase in the amount of water in storage and a rise in water levels in wells. Conversely, when discharge exceeds recharge, the quantity of ground water in storage decreases and water levels in wells decline. Unlike the flat surface of water stored in a surface reservoir, the surface of water stored in a ground-water reservoir may rise in some parts of an area and at the same time fall in other parts. Therefore, significant net changes in ground-water storage cannot be detected unless water-level changes are recorded at points scattered throughout the area. Although there are seasonal changes of several feet in the water table, the drainage divides and directions of movement remained almost constant during the period of study.

A continual discharge of ground water by seepage into streams and by evapotranspiration causes a gradual lowering of the water table, except during and immediately after the melting of snow on the surface or after periods of significant precipitation. During these short periods, recharge to the underground reservoir exceeds the discharge from it and the water table generally rises. In a year of normal precipitation and snowmelt, the recharge to the underground reservoir is approximately equal to the discharge and the reservoir is in a state of approximate equilibrium.

The hydrographs of wells (figs. 12,14) show a general decline of water levels during the winter months. During the winter, ground water continues discharging to streams and lakes, but precipitation, in the form of snow and ice, is stored on the surface and is prevented from recharging ground water by the frost zone in the soil.

$778-0290-65-4$ 
44 GeOlogy, WATER RESOURCES, PORTAGe COUNTy, Wis.

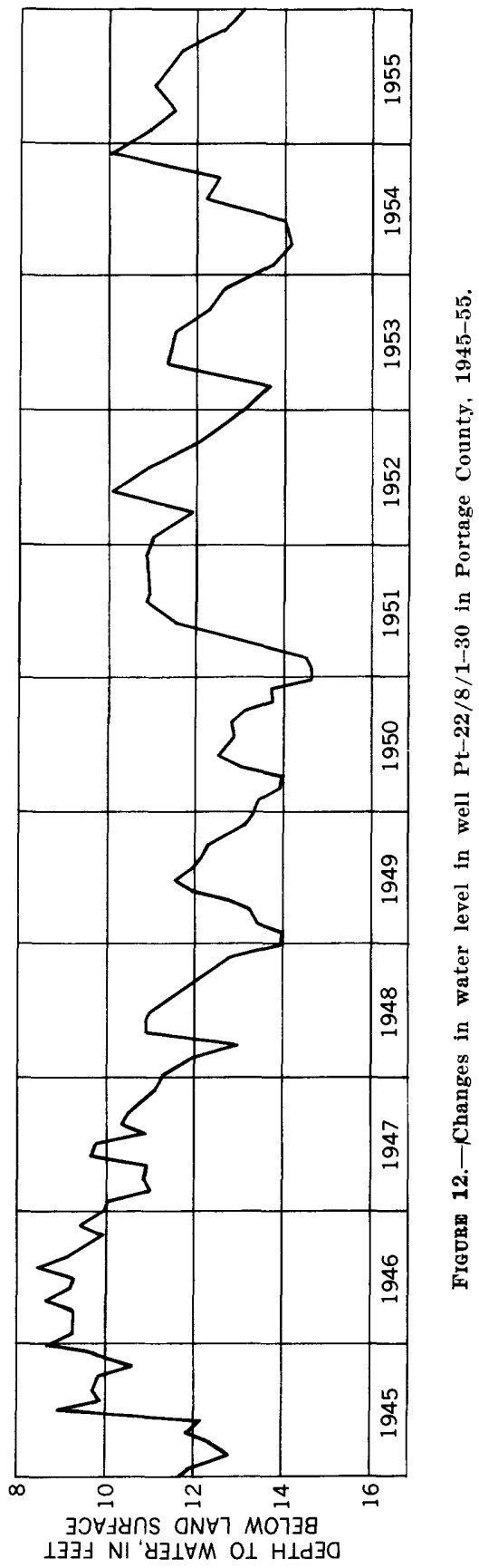



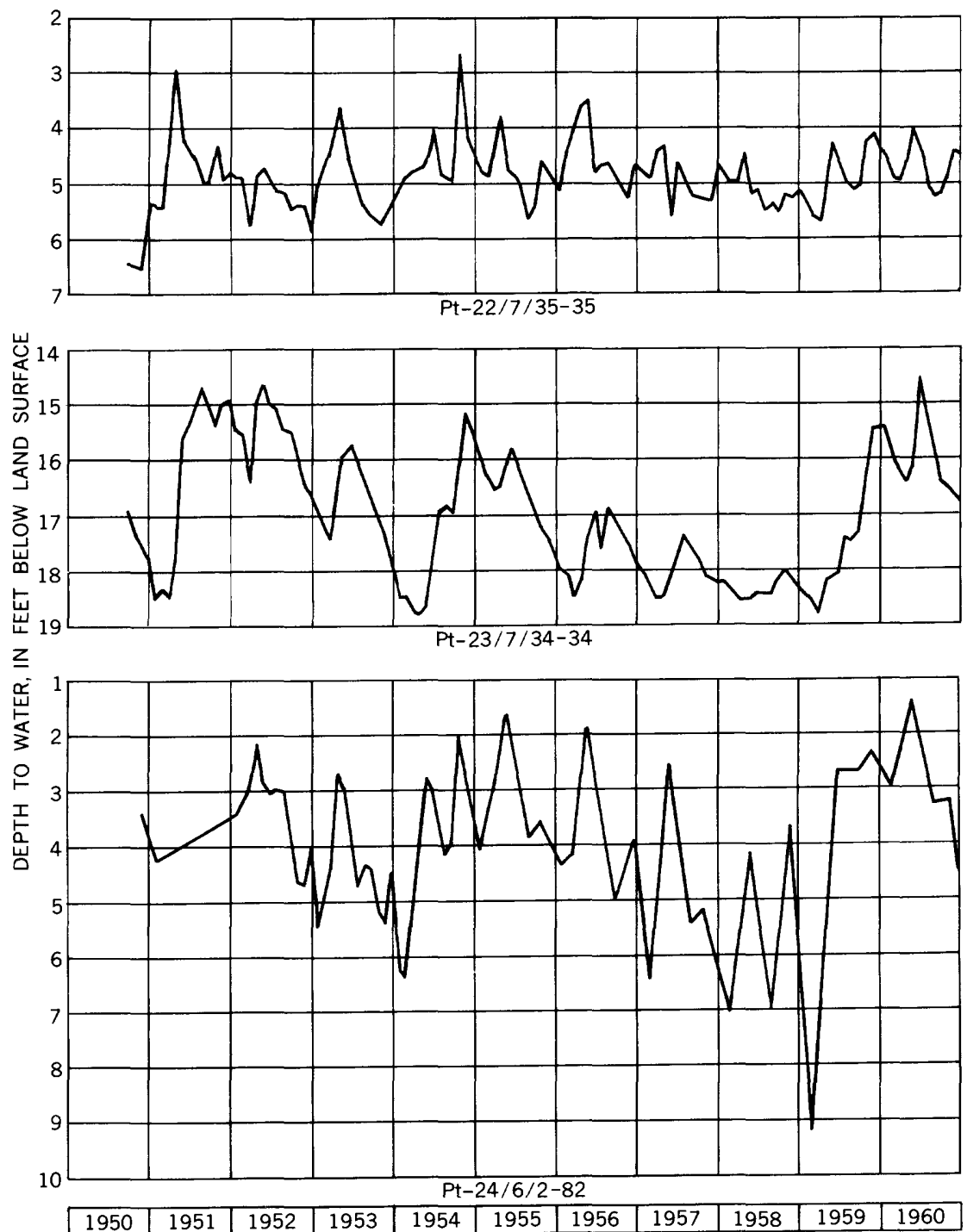

Frgure 13.-Changes in water levels in wells $\mathrm{Pt}-22 / 7 . / 35-35, \mathrm{Pt}-23 / 7 / 34-34$. and Pt24/6/2-82 in Portage County, 1950-60. 

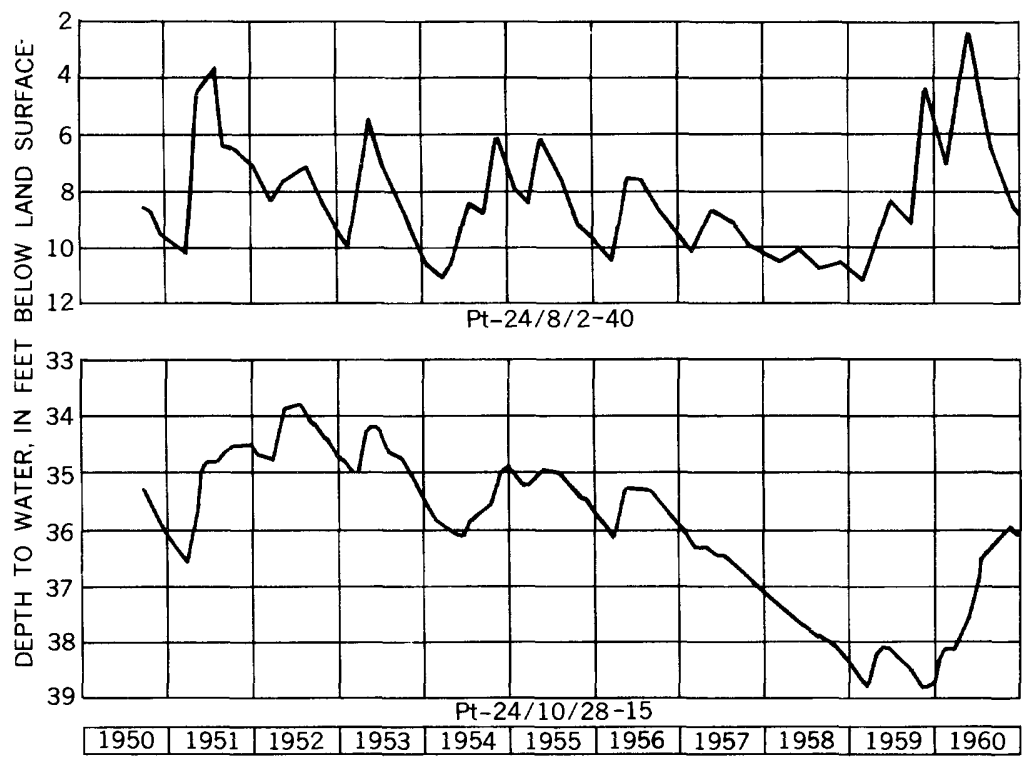

Fradre 14.-Changes in water levels in wells Pt-24/8/2-40 and Pt-24/10/28-15 in Portage County, 1950-60.

The period of the spring rise of water levels from the melting of snow and from precipitation that falls during the period before vegetation begins to remove moisture from the soil is the most important annual period of recharge. As air temperatures rise in the spring, the snow melts, the ground thaws, and parts of the melting snow and of the frost in the soil recharge the ground-water reservoir. The amount of moisture in the ground, the depth of freezing, and the rate of melting influence the amount of snowmelt that soaks into the ground.

The relation between daily precipitation, snow on the ground, daily mean temperature, and water levels in a well at Junction City is shown in figure 15. Daily precipitation does not affect the water level until the frost is gone from the ground and snow has melted. On March 5, the water level began to rise when the mean temperature rose above freezing and continued to rise until the snow had melted from the ground.

Water levels gradually decline during the growing season because the natural discharge exceeds the recharge. Soil moisture removed by vegetation must be replenished by precipitation before ground water can be recharged. Only large amounts of precipitation overcome the soil moisture deficit and cause a rise in water levels or temporarily interrupt the seasonal decline. Water levels often rise in the fall when precipitation occurs after the vegetation has been killed by frost.

Ground-water levels in the county are high during long periods of 
above-average precipitation and low during long periods of belowaverage precipitation. Ground-water levels were generally high in 1945-48, 1951-54, and 1960-61. They were low in 1949-51 and 1956-59.

During the drought of 1956-59, water levels in many wells declined 3 to 6 feet, a few shallow wells failed to yield water, streamflow declined, and stages in land-locked lakes were reported to have

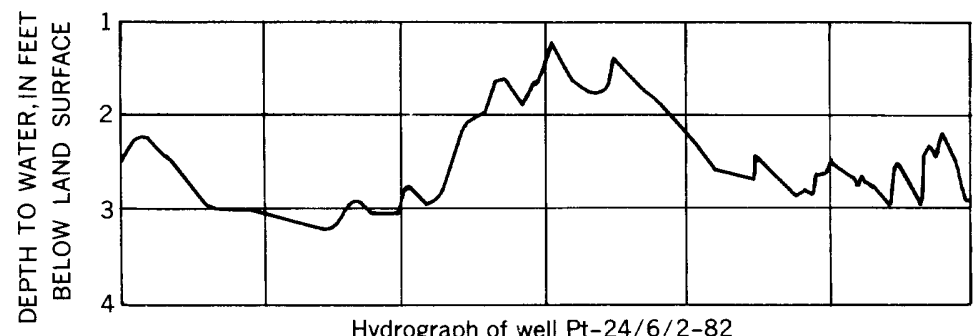

Hydrograph of well Pt-24/6/2-82
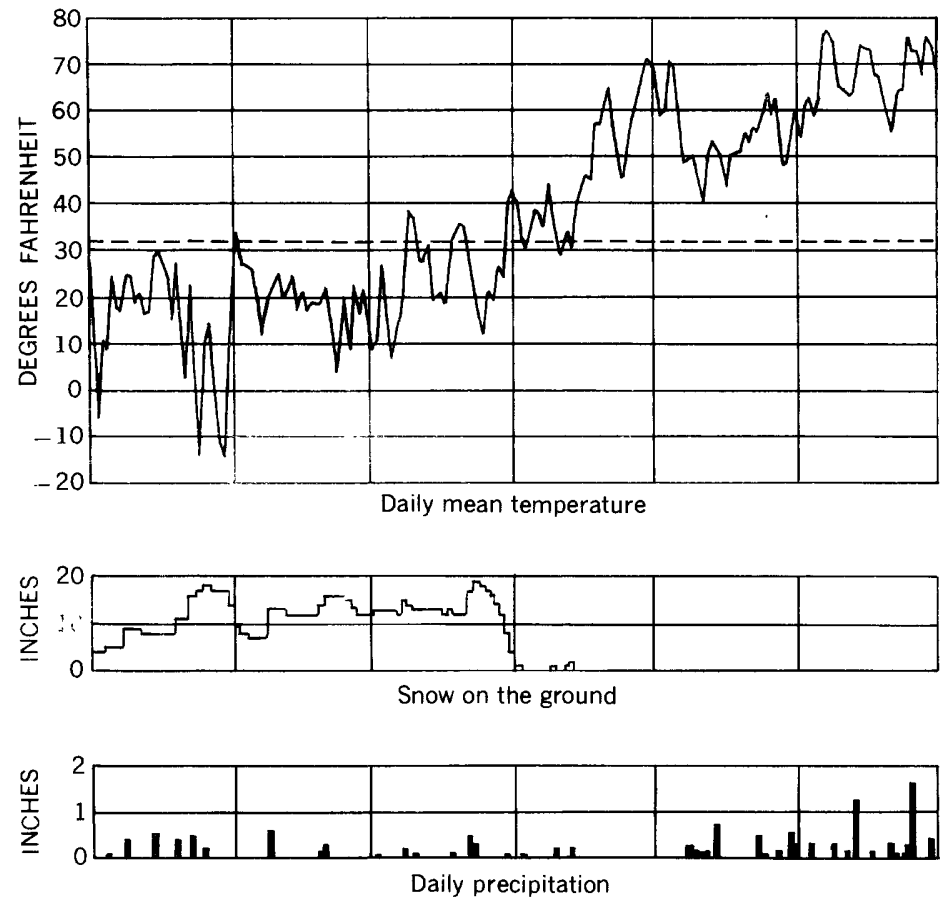

\begin{tabular}{|l|l|l|l|l|l|}
\hline JAN & FEB & MAR & APR & MAY & JUNE \\
\hline
\end{tabular}

Frgure 15.-Changes in water level in well $\mathrm{Pt}-24 / 6 / 2-82$ and climatological data near Stevens Point, Wis., 1952. Climatological records from U.S. Weather Bureau. 
been lower than those observed in many previous years. The decline in stage of land-locked lakes ranged from 2 to 6 feet while the decline in stage of lakes drained by streams was generally less than a foot. Because many of the land-locked lakes are shallow near shore, the decline in stage exposed 20 to 50 feet of lake bottom and shrank ma. terially the lakes area. Although the decline in the stages of lakes drained by streams was slight, the flow of the streams was reduced.

Eridence does not support the commonly held belief that the 1955-59 decline in water levels and lake stages was a result of increased pumpage from irrigation wells. The cause for the decline in the water table, lake stages, and discharge of streams was a cumulative deficiency in precipitation. The amount of withdrawal of water from wells near the lakes is minor. Most of the large withdrawals of water from wells occurred in the Wisconsin River basin, whereas the lakes having large declines in stage were in the Waupaca River basin.

The withdrawal of water by pumping from wells temporarily lowers the water table around individual wells but does not materially affect the conformation of the regional water table. As long as the large-producing wells are spaced at distances sufficient to prevent mutual interference (fig. 11) and the average annual pumpage is less than the average annual recharge, there will be no significant declines in regional water levels.

\section{RECHARGE}

\section{NATURAL RECHARGE}

Precipitation in the form of rain or melting snow is the only significant source of recharge to ground water in Portage County. Underflow is the source of some recharge along the northern and northwestern boundaries, but the amount is too small to be a factor in the water budget.

The capacity of the soil to hold and to transmit water downward determines how much of the precipitation will pass through the soil and recharge the aquifer. Recharge to the aquifer does not occur until soil-moisture deficiencies are overcome. Deficiencies in soil moisture occur when evaporation and water demands of the plants exceed the water entering the soil. Soil-moisture deficiencies are greatest during the months of June, July, and August (fig. 4). Because soils are generally sandy in the sand-plain and the drift provinces, they retain less water and are more permeable than the silt and clay soils in the drift-crystalline rock province. As mentioned on page 35, the sandy soil in the sand-plain province has a high specific yield, and the soil will therefore transmit water rapidly downward to recharge the sand and gravel aquifer. 
The amount of water that recharges the sand and gravel aquifer of the sand-plain province can be estimated by multiplying the estimated field specific yield by the average rise in the water table. In 1953, nearly all the recharge occurred in the spring from snowmelt and precipitation. The average rise in water levels, measured in eight observation wells in the sand-plain province was about 2.5 feet. Although this 2.5 feet is the average rise in water levels, it does not include the effects on the water table of that part of the recharge that was equal to the ground water discharging to streams during the rise. This part of the recharge was calculated by projecting the winter declining trend in water levels to the dates on which the peaks of the spring rise occurred. The arerage difference between the peaks of the water-level rise and the projected declines for the observation wells was 3.1 feet. The average ground-water recharge that occurred during the spring of 1953 was therefore 3.1 feet $\times 12 \times 0.22$ (specific yield) $=8.2$ inches or about 142 million gallons per square mile. During the remainder of the year, the water levels rose about 0.6 foot which is equivalent to about 1.6 inches of recharge. The recharge to the 302 square miles of the sand-plain province in 1953 is estimated as being about 10 inches or about 225 cfs.

Recharge to ground water is partially or wholly rejected in areas where the water table is at or near the surface and where relatively impermeable materials occur near the surface. In the drift-crystalline rock province, extensive marshes, shallow water levels, clay till, and crystalline rocks near the surface all have combined to decrease recharge and increase surface runoff. A comparison of the discharge of the Big Eau Pleine River, in Marathon County, which is considered to be representative of the discharge from the drift-crystalline rock province, with the discharges of the Little Plover and Waupaca Rivers (fig. 6), in the sand-plain and drift provinces, indicates the comparatively small recharge to the drift-crystalline rock province. From March 20 to 26, 1960, runoff from melting snow increased the discharge of the Big Eau Pleine River by a factor of 220 , from 27 cfs to $6,000 \mathrm{cfs}$; the Iittle Plover River by a factor of 6 , from $6.1 \mathrm{cfs}$ to $36 \mathrm{cfs}$; and the Waupaca River by a factor of 5 , from 192 cfs to $988 \mathrm{cfs}$. Each of the basins had 8 to 9 inches of snow on the ground and received little or no precipitation during the period of snowmelt.

In areas where recharge is rejected because the water table is at or near the surface, increased ptimping withdrawals and the attendant decline in water levels should result in recharge to the groundwater reservoirs. A moderate drawdown in water levels in the Mill Creek area near Junction City, could increase recharge to the shallow aquifer. 


\section{INDUCED RECHARGE}

The pumping of ground water from wells near streams, lakes, or marshes, affects local ground-water movement and runoff, and directly or indirectly affects streamflow and the stages of lakes and marshes. The heary pumping of these wells lowers locally the water table below the stage of the river and induces the movement of river water from the stream and toward the wells. The distance of the pumping well from the stream, the rate and duration of pumping, and the geologic and hydraulic characteristics of the aquifer within the pumping area determine the time delay and the magnitude of the effect of the pumping on the stream. The pumping of wells at distances greater than 2,000 feet (fig. 11) from a stream may not induce recharge from the stream but will intercept part of the ground water that would normally move to the stream.

In 1961, recharge was induced from the Plover River near Stevens Point and Whiting and from the Waupaca River near Amherst. A few irrigation wells temporarily induce recharge from smaller streams. The municipal well field for Stevens Point and several industrial well fields are located near the Plover River in order that river water will supplement ground water, increase the yield of the wells, and reduce water-level declines.

A pumping test made on November 2, 1950, at the Stevens Point well field shows the effect that pumping of wells has on the water table and on the movement of water from the Plover River. Figure 16 shows the configuration of the water table after wells 1 and 2 were pumped 24 hours at rates of 1,300 and $1,700 \mathrm{gpm}$, respectively. Well 1 is 65 feet in diameter, 30 feet in depth, and about 700 feet from the Plover River. WVell 2 is 2 feet in diameter, 50 feet in depth, and about 150 feet from the nearest bank of the Plover River. The sand and gravel aquifer is about 55 feet thick.

Prior to pumping, the water level in the wells and the surface of the Plover River were approximately the same level. After the pumps were started, water was withdrawn and cones of depression formed around the pumped wells. As pumping continued, the water levels continued to decline and the cone of well 2 expanded until it intersected the Plover River. The slope of the water table between the Plover River and well 2 induced water to move from the river toward the well. The recharge from the Plover River stopped the eastward expansion of the cone and limited the decline of the water table. The cone of well 2 expanded west ward toward well 1 because of the combined effects of the pumping of both wells on the water table. 

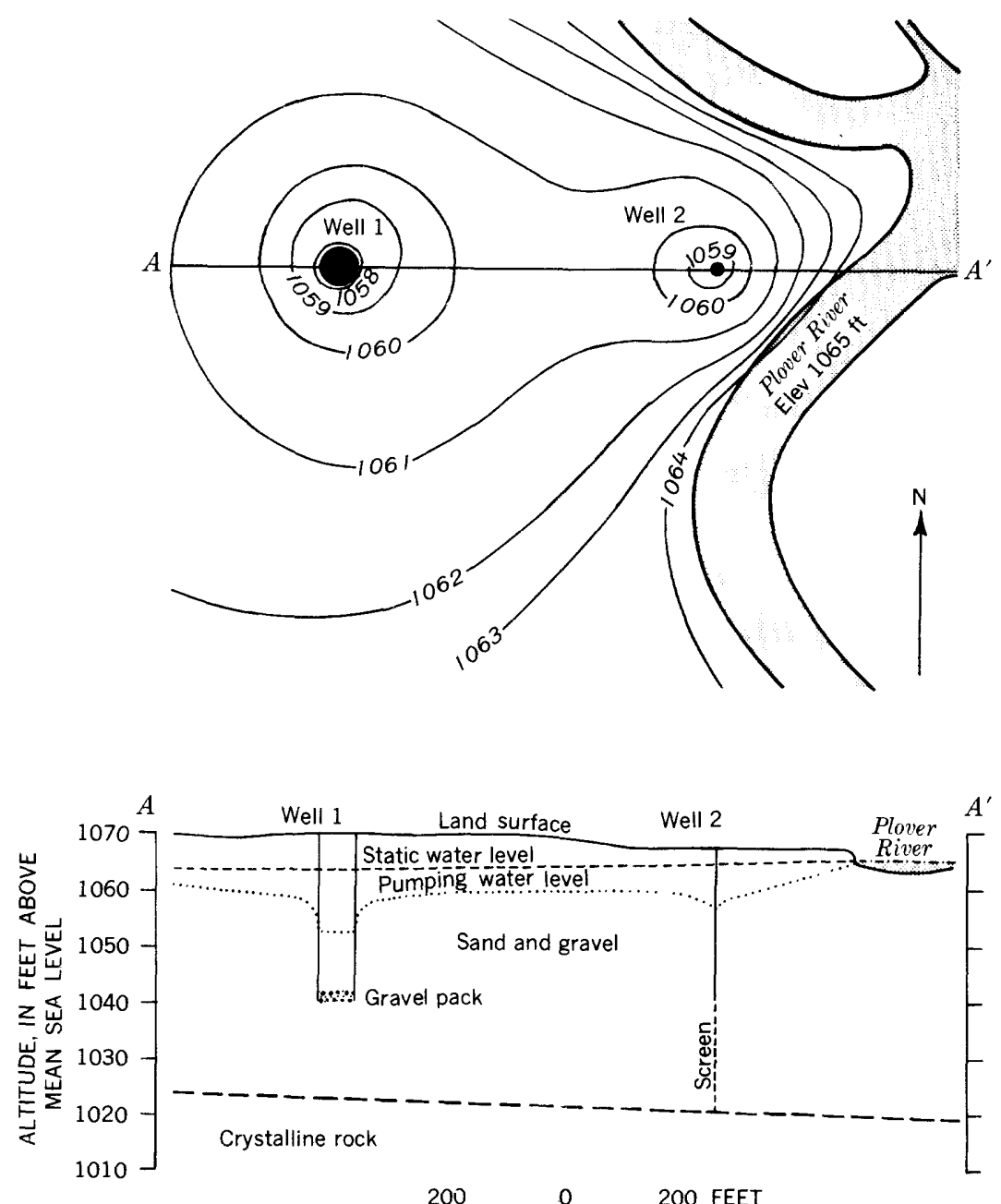

FrgURE 16.- Sketch map of configuration of water table and cross section of part of Stevens Point, Wis., well field, showing effects of pumping from wells.

Any artificial discharge such as pumping from wells will decrease the natural discharge and may increase the recharge. The local lowering of the water table, caused by pumping from wells, dewaters a part of the aquifer and thus allows an increased amount of water to infiltrate and recharge the aquifer. This recharge in turn reduces the surface runoff. If the high-capacity wells are spaced far enough apart to prevent excessice mutual interference and the average annual 
pumpage is less than the average recharge, there will be no significant declines in regional water levels.

\section{DISCHARGE}

Ground water is naturally discharged by seepage into streams, drainage ditches, marshes, and lakes and by evapotranspiration and underflow. Underflow is ground water that moves out of the county before being discharged to streams. The pumping of wells and pits is the chief means for artificial discharge.

\section{GROUND-WATER RUNOFF}

The ground-water contribution to the runoff from Portage County was determined by examining the hydrographs for 1960 and 1961 for the Waupaca River, near Waupaca; for the Little Plover River, at Plover; and for the Big Eau Pleine River, near Stratford, and by estimating the annual rate of ground-water discharge to the streams. The geologic and hydrologic conditions of the Waupaca River basin, the Little Plover River basin, and the Big Eau Pleine River basin are representative of the drift, sand-plain, and drift-crystalline rock provinces, respectively (fig. 6).

The hydrograph and the duration curve (fig. 6) for the Waupaca River near Waupaca indicates that about 90 percent of the runoff, during about 90 percent of the time, is derived from ground water. Inasmuch as the arerage annual runoff of the Waupaca River from Portage County is about 10.5 inches, the arerage annual ground-water discharge is probably about 9 to 10 inches. Examination of the hydrograph and the duration curve (fig. 6) for the Little Plover River, at Plover, indicates also that about 90 percent of the runoff during about 85 to 95 percent of the time, is derived from ground water. The average annual runoff of the Little Plover River is about 10 inches; groundwater discharge is therefore about 9 inches. The ground-water contribution to the Big Eau Pleine River was more difficult to determine because of extremely low flows (no flow was recorded from January 22 to February 5, 1961) and surface-water storage in marshes. However, the ground-water discharge to the Big Eau Pleine River, which occurs about 75 percent of the time (fig. 6), is probably about 10 to 20 percent of the annual runoff or about 1 to 2 inches.

The approximate annual rate of ground-water runoff from the sandplain province is about 9.3 inches or about $210 \mathrm{cfs}$, from the drift province is about 9.5 inches, or about $220 \mathrm{cfs}$, and from the driftcrystalline rock province is about 2 inches, or about $30 \mathrm{cfs}$. The average ground-water contribution to all streams in Portage County is about 75 percent of the runoff or about 8 inches of the 10.3 inches estimated as the annual rate of runoff. 
Ground-water runoff during dry periods is estimated to vary from 0.5 to $1.0 \mathrm{cfs}$ per sq $\mathrm{mi}$ in the sand-plain and drift provinces, and between 0.0 and $0.4 \mathrm{cfs}$ per sq $\mathrm{mi}$ in the drift-crystalline rock province (fig. 6).

Another method of estimating the amount of ground water that discharges from the sand and gravel aquifer in the sand-plain province is to multiply the estimated field specific yield $(0.22)$ by the average decline in the water table. The average water-level decline in eight observation wells in the sand-plain province, which occurred between the crest of the 1953 spring rise of water levels and the lowest water level before the spring rise of 1954 , was about 3.6 feet. The estimated ground-water discharge was therefore about 9.5 inches or about 165 million gallons per square mile. The ground-water discharge from the 302 square mile area of the sand-plain province is estimated as being about $136 \mathrm{mgd}$ (million gallons per day) or about $210 \mathrm{cfs}$. The greatest part of this ground-water discharge enters drainage ditches and streams as ground-water runoff. A small part leaves the county as underflow or is discharged to the atmosphere by evapotranspiration.

The change in ground-water storage for a given period is the difference between the amount of recharge to the ground-water reservoir and the amount of discharge from the reservoir as runoff and evapotranspiration. Between March 1953 and March 1954 the net change in ground-water storage in the sand-plain province was a loss of about 0.5 inch or about $11 \mathrm{cfs}$. The average water-level decline in the observation wells was about 0.2 foot.

\section{UNDERFLOW}

The underflow from the county is considered to be very small, most of the underflow being to Wood and Waupaca Counties. Virtually no underflow enters Marathon, Adams, or Waushara Counties. From a local standpoint, ground water moving out of the county is considered to be a discharge process, although the water remains in the zone of saturation, is available for water users, and will discharge to streams in adjacent counties.

An estimate of the amount of water leaving the county by underflow along the Wood County line may be made by using the formula

$$
Q=T I W
$$

where $Q=$ quantity of water, in gallons per day,

$T=$ transmissibility, in gallons per day per foot,

$I=$ gradient of the water table, in feet per mile, and

$W=$ cross-sectional width of aquifer, in miles. 
The estimated coefficient of permeability of $2,000 \mathrm{gpd}$ per sq $\mathrm{ft}$ times an estimated average thickness of an aquifer of 80 feet gives a coefficient of transmissibility of $160,000 \mathrm{gpd}$ per $\mathrm{ft}$. The aquifer width along the Wood County line is about 11 miles and the water-table gradient is about 4 feet per mile. On the basis of these figures, the quantity of water leaving the sand-plain province by underflow is about $7 \mathrm{mgd}$, or about $11 \mathrm{cfs}$.

The estimated total underflow from the county in 1944, was about $14 \mathrm{cfs}$.

\section{PUMPAGE}

The withdrawal of ground water from wells has increased greatly since 1952, most of the increase being for industrial, irrigation, and municipal use in the sand-plain province. In 1960, the ground-water pumpage in the county was about $13 \mathrm{mgd}$, of which 89 percent was withdrawn from the sand-plain province. The total pumpage from the sand-plain province, about $11.4 \mathrm{mgd}$, represents only about 5 percent of the estimated average annual recharge. About $3.5 \mathrm{mgd}$ of the pumpage from the sand-plain province, mostly irrigation water, was consumed, that is, lost by evapotranspiration. Most of the remainder was discharged to streams, and a small amount was returned to ground water.

\section{EVAPOTRANSPIRATION}

Evapotranspiration from ground water includes direct evaporation of moisture from the capillary fringe of the saturated zone, where the water table is near the surface, and transpiration by plants and trees where their roots extend to the capillary fringe. In Portage County, evapotranspiration undoubtedly consumes a significant amount of ground water because the water table is seasonally at or near the surface of about 60 square miles of land. The loss of ground water by evapotranspiration is included in the estimates of evapotranspiration from soil moisture made earlier in this report.

\section{QUALITY OF WATER CHEMICAL CHARACTER}

Precipitation contains very little mineral matter in solution. However, as water passes over and through the ground, it dissolves organic and clay acids and mineral substances. The character and amount of mineral matter dissolved depends on the amounts of dissolved gases, the chemical nature of the soil and rock materials, and the nature and duration of their contact with water.

The rate of movement and duration of time that the water is in contact with rocks are important controls on the concentration of dissolved substances. Water that has had only a short duration of contact with the rock while moving between its point of recharge and 
point of discharge will contain less dissolved solids than will water that has moved more slowly along a similar path, the character of the rock and other factors remaining constant.

To appraise the general chemical quality of the water in the aquifers, 69 samples of water were collected from wells and analyzed by the Wisconsin State Laboratory of Hygiene and the U.S. Geological Survey. Representative analyses are given in table 6 . The analyses show only the dissolved mineral content of the water and do not indicate sanitary conditions.

\section{HARDNESS}

Water having a hardness of 0 to $60 \mathrm{ppm}$ (parts per million) is generally considered soft and is suitable for nearly all purposes. Water having 61 to $120 \mathrm{ppm}$ hardness is considered moderately hard but it is usable for most purposes except in high-pressure steam boilers. Water whose hardness ranges from 121 to $180 \mathrm{ppm}$ is considered hard, and laundries and industries may have to soften it. If the hardness is more than $180 \mathrm{ppm}$, the water is considered very hard and is generally softened for most uses. Where water supplies are softened, the hardness is generally reduced to less than $90 \mathrm{ppm}$. The distribution of hardness in ground water in Portage County is shown in figure 17.

Water from wells in the drift province is generally hard to very hard (fig. 17). Dolomite, a common constituent in glacial till and ice-contact deposits in this area, is considered the source of the calcium and magnesium that are the principal causes of hardness. Other constituents, such as iron, manganese, and strontium, also cause hardness but generally they are not present in sufficient quantities to have an appreciable effect on the hardness.

Water in the outwash sand and gravel near the Wisconsin River and the western part of the sand-plain province is soft and low in total dissolved solids. The availability of a water supply of such excellent quality is of prime importance to paper-manufacturing companies in this area.

A local area having very hard water occurs in Tps. 21 and $22 \mathrm{~N}$., and Rs. 7 and 8 E. (fig. 17). The slope of the water table is about 3 feet per mile (pl. 2) and the high concentration of hardness is attributed to the slow movement of the ground water.

\section{IRON}

Iron in water in excess of $0.3 \mathrm{ppm}$ is objectionable because iron precipitates cause reddish-brown stains on porcelain plumbing fixtures, enamel ware, and clothing or other fabrics, and interfere with paper manufacturing, dyeing, tanning, and other industrial processes. (U.S. Public Health Service, 1962). 


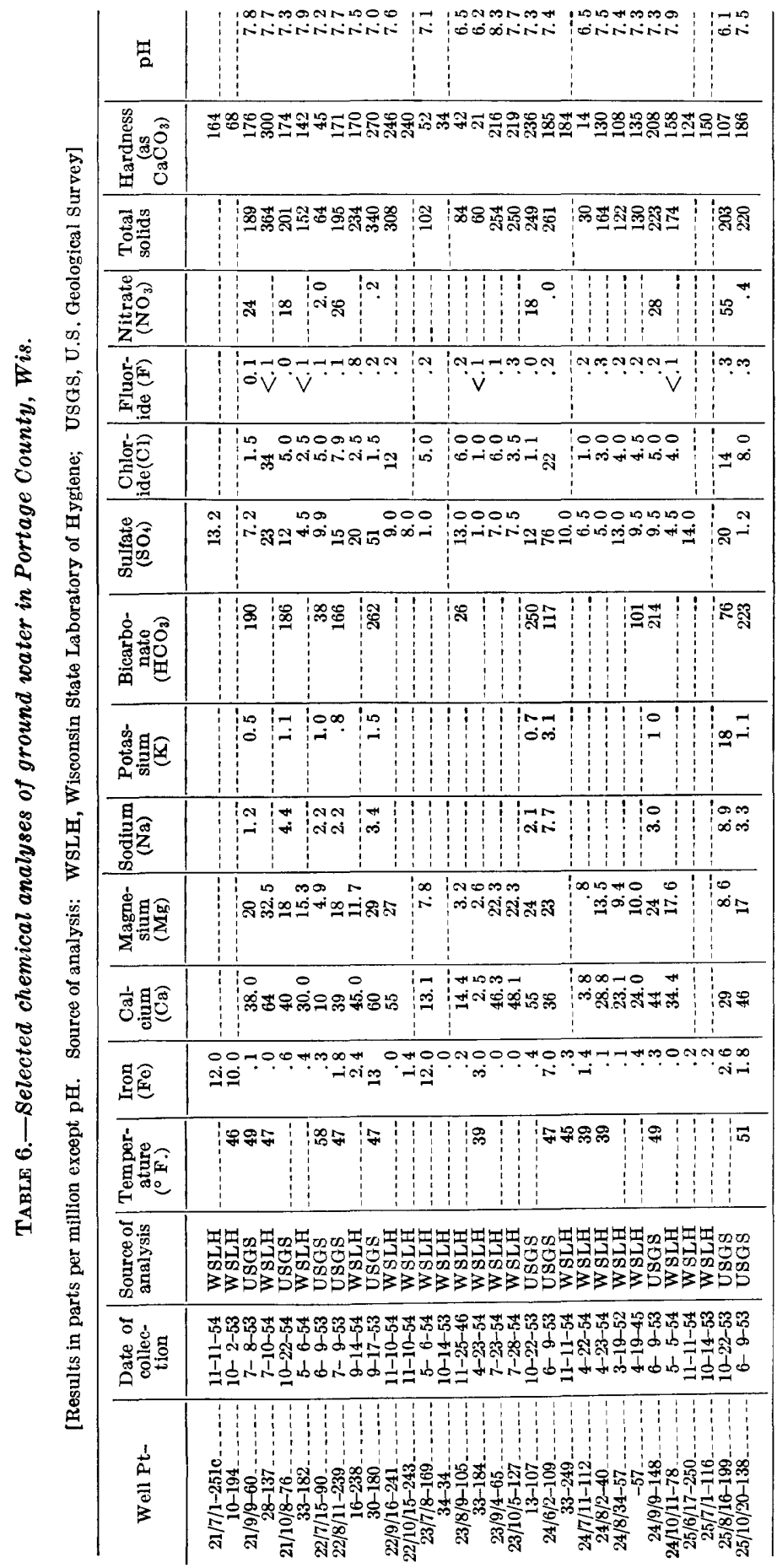




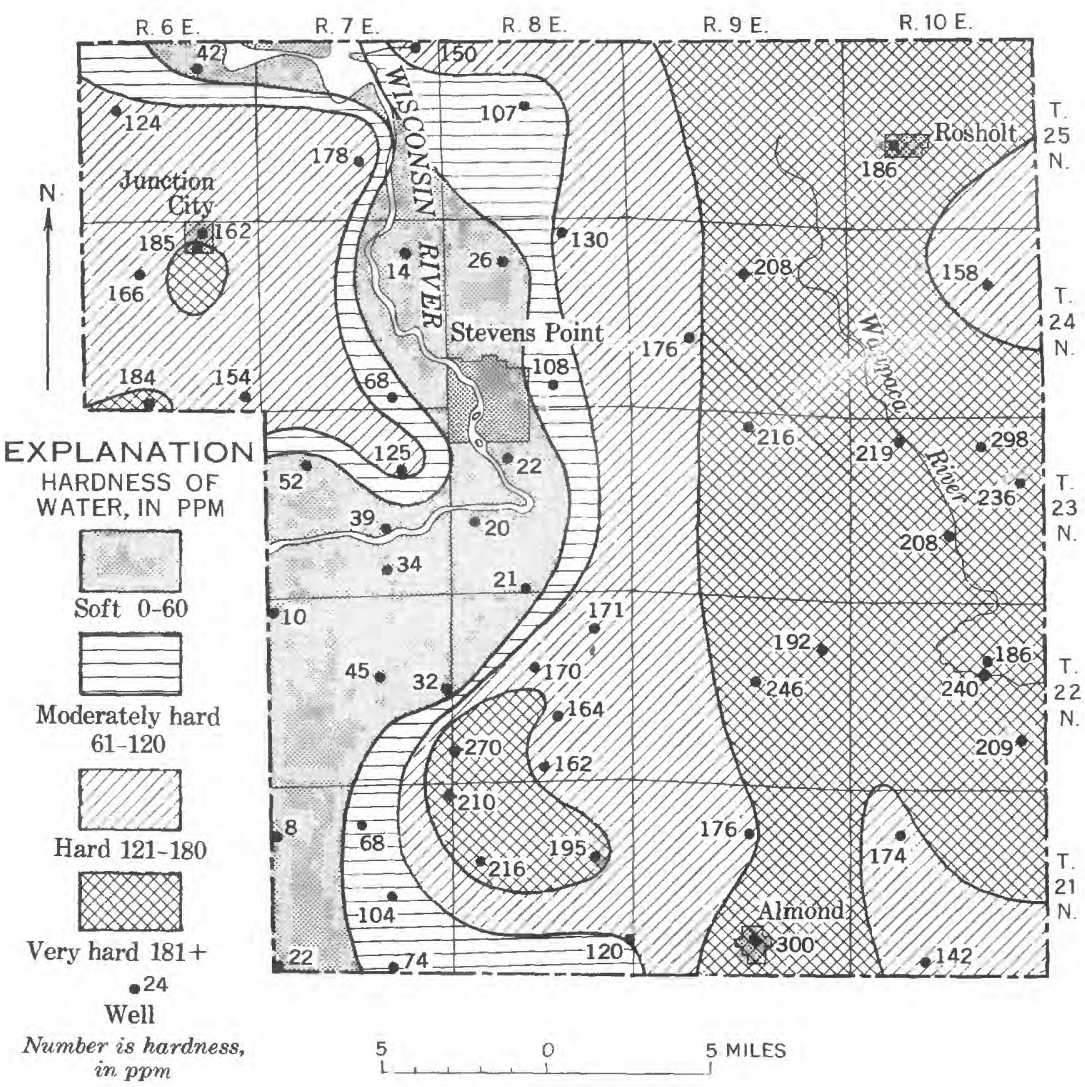

Frgure 17. - Map of Portage County showing distribution of hardness in ground water. Base from Wisconsin Highway Commission road map.

Objectionable quantities of iron are present in water from wells in several areas of the county (fig. 18). Nearly two-thirds of the 69 samples of water analyzed had more than $0.3 \mathrm{ppm}$ of iron. The occurrence of the iron is only partially associated with the minerals which comprise the aquifer. The most important factors appear to be that water having an objectionable content of iron occurs in swamp and marsh areas or in areas where the movement of ground water is very slow.

Some iron is dissolved from almost all rocks. The iron in solution in the ground water is under reducing conditions and is mainly in the ferrous state. The ferrous salts are unstable in the presence of oxygen or air and are changed to the ferric state through oxidation. In this form the iron is so nearly insoluble that most of it is precipitated. For this reason, most surface streams, lakes, dug pits, and springs contain less than $1 \mathrm{ppm}$ of iron in solution. The ferric ion has a tendency to 


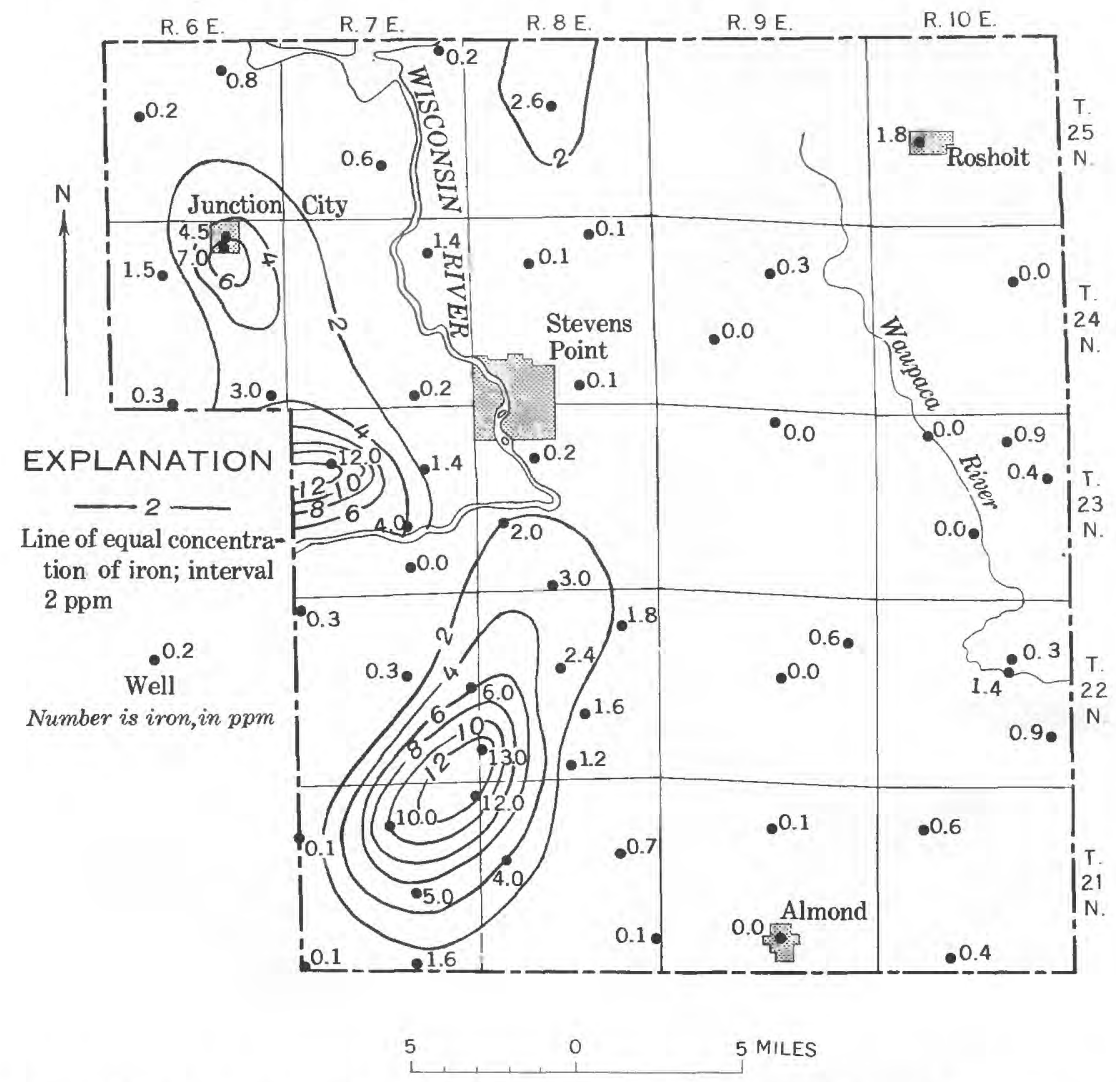

Frgure 18.-Map of Portage County showing distribution of iron in ground water. Base from Wisconsin Highway Commission road map.

form complexes with organic substances and impart a color to water (Hem, 1959).

The iron content of water is exceptionally high in the sand-plain province in the southwestern part of the county (fig. 18). The greatest concentration of iron, $13 \mathrm{ppm}$, is centered at the junction of Tps. 21 and 22 N., and Rs. 7 and 8 E., where reducing conditions occur and where the very slow westward movement of ground water has allowed the reduction products to concentrate in the old marsh area. The anaerobic decomposition of peat contributes to the reducing environment.

Buried ridges of sandstone that locally retard the movement of ground water may be contributing factors to the local accumulation of hardness and iron in the southwestern part of the county (figs. 8, 17, and 18). Such buried ridges occur to the west and to the east of the area of very hard water and excessive iron. 
Excessive amounts of iron occur also west of Stevens Point in sandstone and in thin deposits of sand and gravel. Poor drainage, reducing conditions in numerous swamps and marshes, and iron-oxide cemented sandstone contribute to local iron concentrations of as much as $12 \mathrm{ppm}$.

The high concentration of iron in ground water in the Junction City area may be attributed to the leaching of schist bedrock high in ironbearing minerals, to a reducing environment, and to the slow movement of ground water. The poor drainage of the area and the thin covering of drift has contributed to the decomposition of the schists.

The concentration of iron in ground water varies not only from area to area but also with depth. Water from test well Pt-21/7/1-251, equipped with an 18-inch well screen, was sampled at depths of 3,8 , 13, and 19 feet below the water table. The iron content of the water increased from $1.5 \mathrm{ppm}$ at 3 feet, to $12.0 \mathrm{ppm}$ at 8 and 13 feet, and to $20 \mathrm{ppm}$ at 19 feet. At the same time, the sulfate content of the water varied from $27.2 \mathrm{ppm}$ at 3 feet, to $10.0 \mathrm{ppm}$ at 8 feet, to $13.2 \mathrm{ppm}$ at 13 feet, and to $6.0 \mathrm{ppm}$ at 20 feet.

\section{sODIUM}

Sodium in ground water used for irrigation is a problem in arid areas where base exchange of sodium for calcium or magesium in soils reduces permeability. In Portage County, however, sodium in ground water used for irrigation is not a problem because the sodium content of ground water is very low, about $4 \mathrm{ppm}$; the soil is sandy and is not subject to base exchange; and recharge is about 10 inches per year.

\section{TEMPERATURE}

An important advantage of the use of ground water for industrial purposes is its relatively constant temperature. The temperature of water discharged from wells deeper than about 60 feet averages about $48^{\circ} \mathrm{F}$. and varies less than $2^{\circ} \mathrm{F}$. The temperature of water discharged from shallow wells ranges from $37^{\circ} \mathrm{F}$. to $58^{\circ} \mathrm{F}$. and averages about $50^{\circ} \mathrm{F}$. This wide range in temperature is caused by seasonal variations in air temperature. The range in water temperature diminishes with the depth of the well.

The temperature of ground water entering streams is very important to the propagation of trout, because trout require cool and constantly flowing water. Most of the streams in the sand-plain and drift provinces meet these requirements and have good trout populations.

\section{POLLUTION}

The disposal of domestic and industrial wastes into the ground and into streams has created locally complex problems of pollution 
of the county's water resources. Although the treatment of sewage and waste waters is steadily improving, the problem of pollution is expected to continue because greater volumes of liquid waste are constantly being produced. The Wisconsin and Waupaca Rivers are the streams most utilized for direct discharge of treated and partially treated domestic and industrial wastes. Wastes from cesspools or septic-tank systems are the principal source of pollution of ground water.

The disposal of refuse on the surface is another possible source of pollution to ground water. Both biological and chemical contaminants may be leached from refuse by the movement of water through the refuse. Sand and gravel deposits act as a natural filter bed and restrict the movement of bacterial contammants into the groundwater reservoir. Chemical contaminants, because they are usually in solution, are not removed by the natural filter and may contaminate ground water.

Water is said to be polluted if it contains manmade substances in concentrations that are objectionable for intended uses. Water that has been polluted may have displeasing tastes, odors, and colors; detergents or natural organic constituents may create foam, or the water may contain nitrates, bacteria, and viruses that may be detrimental to health. A colorless water may be polluted. It is especially important to safeguard the quality of a ground-water supply from pollutants because once an aquifer is polluted, it may take months or years for the pollutant to be flushed out.

Pollutants generally decrease in concentration with time, with chemical or physical sorption, and with dilution through dispersion. Some pollutants may become harmless and undetectable near the points of release and others may travel for great distances.

Dairy plants and cheese factories generally provide complete treatment or use land disposal of liquid wastes. Although there are no sulfite pulp mills in the county, mills located upstream on the Wisconsin River contribute partially treated sulfite-liquid waste to the stream. The treated discharge of paper mills in Portage County is not considered to be a source of pollution to the Wisconsin River.

The piezometric map, plate 2, may be used to define the path of movement of liquid waste through the ground-water reservoir. The approximate direction of movement can be determined by extending a flow line from the point of discharge and at approximately right angles to the water-table contours until the flow line extends back to the point where the liquid waste was introduced. This method may also be used to determine the best direction for locating a water supply away from a source of pollution. 
Although a heavily pumped well near a river may induce movement of polluted river water toward the well, the sand and gravel in the aquifer acts as a filtration system that generally removes bacterial pollutants.

\section{WATER USE}

The abundant water resources of the county are developed on a moderate scale. Virtually all water for domestic and public supply is derived from wells. Most of the water used for irrigation and industry is supplied from wells and pits. Ground water supplies about 75 percent of the water used by stock. Surface-water resources are used for power generation, for industry, and for wildlife and recreation.

The total amount of ground water withdrawn in 1960 in Portage County is estimated to be 4.8 billion gallons or an average withdrawal rate of $12.8 \mathrm{mgd}$. The estimated rate of discharge ranged from about $9 \mathrm{mgd}$ in the winter months to about $15 \mathrm{mgd}$ in the summer months. The use of water for irrigation is generally restricted to June, July, and August. Table 7 gives the rates of ground-water use in 1960 by type of use and by ground-water province. Of all ground water used in the county in 1960 , about 89 percent was withdrawn from the sand-plain province, about 9 percent from the drift province, and about 2 percent from the drift-crystalline rock province.

About one-third of all ground water withdrawn in 1960 in the county is estimated to have been discharged to the atmosphere or incorporated in the products of regetative growth, food processing, or manufacturing. Irrigation consumed the largest quantity of water, about $3.0 \mathrm{mgd}$, and municipalities, industries, and stock consumed about $0.8 \mathrm{mgd}$.

Portage County's water budget for 1960 showed that about 300 mgd of ground water was released to streams. In 1960, estimated ground-water use totaled $12.8 \mathrm{mgd}$ or about 4 percent of the renewable supply. Only $3.8 \mathrm{mgd}$ or about 1.2 percent of the renewable supply was consumed. The remaining $9 \mathrm{mgd}$ that was withdrawn discharged into streams or recharged ground water. It is evident, therefore, that the consumptive use of water is insignificant to the county's available and renewable water supply.

Although the current use of water in Portgage County is only about 4 percent of the renewable supply, the withdrawal of water for industrial, municipal, and irrigation uses has increased rapidly in the last 7 years and is expected to increase at the same or at an even greater rate during the next 10 years. 
TABLE 7.-Use of ground water in ground-water provinces in Portage County, Wis., 1960

[Use: D, Domestic; S, stock; PS, Public supplies; Ind, industrial; Irr, irrigation]

\begin{tabular}{|c|c|c|c|c|c|c|}
\hline \multirow{2}{*}{ Ground-water provinces } & \multicolumn{6}{|c|}{ Use (million gallons per day) } \\
\hline & $\mathrm{D}$ & $\mathrm{s}$ & PS & Ind & Irr & Total \\
\hline $\begin{array}{l}\text { Sand-plain } \\
\text { Drift-crystalline-rock- } \\
\text { Drift- }\end{array}$ & $\begin{array}{r}0.2 \\
.1 \\
.2\end{array}$ & $\begin{array}{r}0.1 \\
.1 \\
.1\end{array}$ & $\begin{array}{r}2.1 \\
.0 \\
.1\end{array}$ & $\begin{array}{r}5.6 \\
.1 \\
.3\end{array}$ & $\begin{array}{r}3.4 \\
.0 \\
.4\end{array}$ & $\begin{array}{r}11.4 \\
.3 \\
1.1\end{array}$ \\
\hline $\begin{array}{l}\text { Total water withdrawn } \\
\text { Total water consumed }\end{array}$ & $\begin{array}{r}0.5 \\
.0\end{array}$ & $\begin{array}{r}0.3 \\
.3\end{array}$ & $\begin{array}{r}2.2 \\
.2\end{array}$ & $\begin{array}{r}6.0 \\
.3\end{array}$ & $\begin{array}{l}3.8 \\
3.0\end{array}$ & $\begin{array}{r}12.8 \\
3.8\end{array}$ \\
\hline
\end{tabular}

\section{PRIVATE INDUSTRY}

Private industry is important in the county for it provides more jobs than do agriculture and forestry. Of about 60 manufacturing and processing industries in the county, the chief are production of paper, furniture, fishing equipment, milling products, condensed milk, cream, butter, and cheese. The withdrawal of ground water for industrial uses increased from an estimated $2.6 \mathrm{mgd}$ in 1954 to an estimated $6.0 \mathrm{mgd}$ in 1960, an increase of about 130 percent in 6 years.

Paper-manufacturing plants are the largest users of ground water in the county. Three paper mills, along the Wisconsin River between Stevens Point and Plover, use ground water for much of their processing.

The principal industrial use of surface water is for cooling and for the production of paper. In 1960, the withdrawal of surface water, nearly all of it from the Wisconsin River, was about $0.3 \mathrm{mgd}$. The water is returned to the river unchanged in quantity but generally changed in temperature and quality. This change does not measurably affect the temperature and quality of the Wisconsin River because of the large flow of the river.

An average of about 12,600 cfs of water from the $W$ isconsin River was used in 1960 to generate electric power. The DuBay, Stevens Point, Wisconsin River Division, and Whiting-Plover hydroelectric stations used about $3,700,3,600,3,800$, and $1,500 \mathrm{cfs}$, respectively. Much of the water was used more than once. In 1960, these stations generated about 129 million kilowatt hours of electrical energy.

Water power is a nonconsumptive use because the water is returned to the river unchanged in quantity and quality. However, water stored in the reservoirs has a high rate of evaporation. The amount of evaporation has been included in the estimate of evaporation from bodies of surface water discussed earlier in the report (p. 9). 


\section{PUBLIC SUPPLY}

The cities of Stevens Point and Amherst have public water supplies obtained from wells. Residents of urban communities in the remainder of the county obtain water from private wells.

The water supply for Stevens Point comes from five wells that served a population of 17,837 persons in 1960. All the wells are within 1,000 feet of the Plover River and tap about 60 feet of unconsolidated sand and gravel. The monthly pumpage in 1960 ranged from about $1.4 \mathrm{mgd}$ in December to $3.4 \mathrm{mgd}$ in July and averaged $1.9 \mathrm{mgd}$. The total pumpage in 1960 was 709 million gallons.

Pumpage from wells close to the Plover River induces river water to recharge the aquifer. This induced recharge increases the yield and specific capacity of the wells.

The water supply for Amherst (1960 population, 596) is obtained from a well that is 60 feet deep and taps water in unconsolidated sand and gravel. The well is within 50 feet of the Waupaca River. In 1960 , total pumpage was about 19.9 million gallons, and the daily pumpage ranged from 239,400 gallons on August 1 to 28,800 gallons on October 19.

\section{DOMESTIC AND STOCK}

Nearly all farm homes and all urban homes, not using water from a public water system, obtain water for domestic use from private wells. The wells are generally of small diameter and yield less than $20 \mathrm{gpm}$. The installation of modern plumbing facilities and the increasing water requirements of dairy farms have increased the rural consumption of water in recent years. Although the daily use of water differs greatly among people, the assumed average is about $45 \mathrm{gpd}$ per person. The total domestic water use in rural areas in the county in 1960 is estimated to have been about $0.5 \mathrm{mgd}$.

In 1960, about 140 million gallons of water, or about $0.4 \mathrm{mgd}$, were used for stock. This estimate was obtained by assuming average daily use (MacKichan and Kammerer, 1961) for stock reported in the 1960 agricultural census from Portage County (Wisconsin Department Agriculture , 1960). About $0.1 \mathrm{mgd}$ of the water used for stock was withdrawn from surface water and $0.3 \mathrm{mgd}$ from ground water.

\section{IRRIGATION}

Supplemental irrigation is becoming an increasingly important use of water in the county. Although Portage is one of Wisconsin's leading potato-producing counties and potatoes are its principal cash crop, the production of snap beans, cucumbers, and other field crops is rapidly growing. The gain in irrigated land from 2,800 acres in 
1954 to 6,900 acres in 1960 is indicative of the rate of growth. Figure 19 shows that the annual quantity of ground water pumped for irrigation increased from an estimated 900 acre-feet in 1949 to about 1,800 acre-feet in 1954 and to an estimated 4,300 acre-feet in 1960.

The use of water from pits has decreased because: (1) Pits require periodic maintenance; (2) pits and spoilbanks take land out of production; (3) it is not economically feasible to construct pits where the water table is more than 10 feet below the land surface; (4) many of the mechanized irrigation systems are designed for wells; and (5) properly constructed wells in sand and gravel aquifers have greater sustained yield.

During the 1959 growing season, when precipitation and soil moisture were above average, the pumpage decreased but the total number of wells increased (fig. 19). The average withdrawal of water from an irrigation well in 1959 was about 37 acre-feet; in 1958 it was about 53 acre-feet and in 1960 about 48 acre-feet.

The use of surface water for irrigation in 1960 was limited to shortterm withdrawals of water from a lake and a stream in the eastern part of the county. Approximately 90 acre-feet of surface water was applied during the growing season to about 170 acres. . During the last few years, irrigation with surface water has gradually decreased

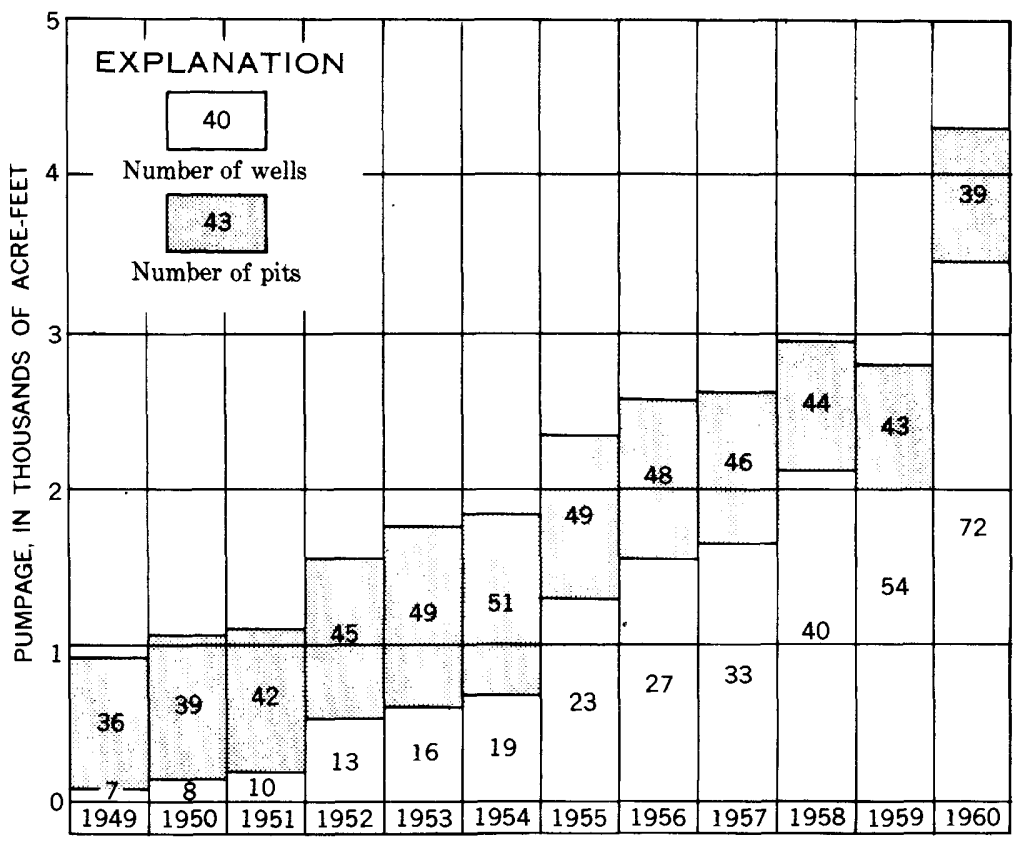

Figure 19.-Estimated pumpage for Irrigation from wells and pits in Portage County, $1949-60$. 1.0 acre-foot $=325,850$ gallons. 
whereas irrigation with ground water has rapidly increased. One reason is that ground water generally can be obtained within the area to be irrigated. Another reason for this increase is that the use of ground water is not as restricted by law as is the use of surface water.

Wisconsin has in force a modification of the riparian doctrine which permits the diversion of surface water for irrigation with the consent of riparian owners, but no water shall be so diverted to the injury of public rights in the water. Practically all surface waters in Wisconsin are owned by the State and held in trust for the benefit of all citizens.

The Wisconsin Public Service Commission issues permits under Wisconsin Statute 30.18 (1959) for agricultural irrigation. The temporary diversion of surplus water (storm runoff) is lawful under this statute.

A land owner has the legal right to unrestricted use of ground water. The only exception is a Wisconsin Statute that gives the Wisconsin State Board of Health the authority to protect the ground-water supply used by a municipality from being interfered with by the development and operation by others of a well having a capacity of more than $100,000 \mathrm{gpd}$.

\section{WILDLIFE AND RECREATION}

The wildlife and recreational uses of water such as swimming, boating, fishing, and hunting cannot be measured in million gallons per day or in dollars; however, recreation is a vital and rapidly growing industry that involves many people in the area. Water is a necessity for the continued propagation of wildlife.

Water for commercial and private tourist establishments and cottages, located on lake and stream shores, is obtained generally from small-diameter wells. The annual withdrawal of ground water by the recreational industry in the county is about 10 million gallons, or about $0.1 \mathrm{mgd}$ during the summer months. This special use was included with "domestic use" in table 7.

\section{WATER-MANAGEMENT PROBLEMS AND THEIR POSSIBLE SOLUTIONS}

Portage County has an abundance of good quality water available for many uses, but the increasing demands for water may be affected by diverse water-management problems, such as pollution of water, inadequate water supply, excessive declines in water level, undesirable chemical quality of water, conflict of interests, and floods.

\section{POLLUTION}

The pollution of ground water is a present and potential problem in many local areas of the county. Increased chances for pollution 
exist in those areas where (1) housing is concentrated and waste is discharged into absorption units of septic-tank systems and into pit privies; (2) the water supply is obtained from a shallow well screened just below the water table; (3) the water table is near the land surface; (4) the soil is permeable, and the pollutant moves downward readily into the aquifer; $(5)$ the aquifer consists of sand and gravel or fractured granite; and (6) the aquifer is thin and underlain by impermeable clay or granite. Although a few of these conditions exist in most parts of the county, the greatest chances for pollution are in the Junction City, Whiting, Plover, Stevens Point, Bancroft, Rosholt, and Amherst areas.

One method of correcting the ground-water pollution problem in a concentrated housing area is to construct a central sewage-treatment system. Stevens Point, Whiting, Almond, and Amherst have such systems (Wisconsin State Board of Health, 1962). Another method would be to develop a central water-supply system isolated from areas of pollution.

In areas where ground water is polluted, supply wells should be located at a maximum distance and in an appropriate direction (upgradient) from the sources of pollution. An alternate solution might be to deepen the wells, where practicable, to a depth where the hydraulic pressure is greater than that near the surface.

At present, the streams and lakes in the county are generally free of pollution. An exception is the Wisconsin River that locally contains diluted and treated or partly treated sanitary sewage and industrial wastes. The oxygen in the river water gradually decomposes much of the pollutants in the stream; however, if the river becomes overoladed with wastes, the natural oxygen in the water cannot cope with the load.

\section{INADEQUATE WATER SUPPLY}

The drift-crystalline rock province has thin aquifers that store only small supplies of water and yield little water to streams during dry periods. Although large yields of water probably cannot be obtained from the province, it is not currently an area of "water shortage." Rather, the area is undeveloped and there is no great demand for large volumes of water.

The residents of Junction City, the only community in the province, have had some difficulty in obtaining adequate supplies of good quality water. Supplies for domestic use (yields of a few gallons per minute) can be obtained within the village limits, but not for large-scale uses.

If the village of Junction City expands in the future and requires a large supply of water for municipal and industrial development, 
water can be obtained from a more distance source and transported to the village by pipeline.

A possible source for Junction City's water supply might be to develop water from thin deposits of saturated sand and gravel near Mill Creek, several miles to the east of Junction City. An array of shallow wells or a collector system are possible methods of development that would provide a water supply that entailed the least amount of water-level decline. Other possible sources might be to develop a surface reservoir on Mill Creek or to obtain water from the Wisconsin River ( 5 miles to the east) or from the Little Eau Pleine River (6 miles to the north).

\section{EXCESSIVE DECLINES IN WATER LEVEL}

Recharge to the sand and gravel aquifers in the sand-plain and drift provinces is sufficient to permit additional withdrawals without excessive lowering of the regional water levels. However, excessive declines of local water levels might occur if wells are not spaced properly to minimize interference. The spacing between wells is determined by the rate and duration of pumping and the hydraulic characteristics of the aquifer. Figure 16 may be used to estimate the spacing necessary between wells to prevent excessive declines in water level. In the sand-plain province, an adequate distance between wells pumped at rates of $500 \mathrm{gpm}$ is probably about 1,000 feet and between wells pumped at rates of $1,000 \mathrm{gpm}$ is probably about 2,500 feet. Observations of water levels and pumpage should be made regularly to give early warning of declining water levels and possible overdraft.

\section{UNDESIRABLE CHEMICAL QUALITY}

The chemical quality of ground water in Portage County is generally good, but geologic and hydrologic factors are responsible for local areas having undesirable amounts of iron in the water and for large areas haring hard to rery hard water. Although water of such quality may not be considered desirable for certain uses, it can be made satisfactory for most uses by treatment. The maps showing the general distribution of hardness and iron in water (figs. 17, 18) may be used as guides in locating water having a suitable quality for industrial, municipal, or domestic uses. Hardness and iron in water are not considered undesirable qualities for irrigation use.

\section{CONFLICT OF INTERESTS}

In the future, even more than at present, the water resources of the county will be in demand for outdoor recreation, and selected areas will need to be protected for the preservation of wildlife. Water 
uses that make radical changes in the quantity or quality of water in streams, lakes, or marshes may affect wildlife that depends on water, may discourage boating and swimming, and may reduce the tourist trade. Generally, recreation interests and wildlife require constantflowing streams, nonpolluted water, and lake levels subject to only minor fluctuations.

As mentioned previously, the pumping of irrigation wells and pits has neither noticeably depleted the flow of streams nor affected the stages of lakes. If future wells are located properly and the annual average pumpage is less than the average annual recharge, the surface-water resources will not be seriously depleted. The collection of additional data on streamflow, ground-water levels, and pumpage in critical areas is necessary to determine long-term effects of water use upon the hydrologic regimen.

Although the increasing use of water by municipalities and industries in the Stevens Point area will reduce the flow of the Plover River at the Stevens Point area, it will not affect materially the upstream flow.

A possible aid to the problem of the conflict of interests over the use of water would be to designate areas deemed to have the best potential recreational and wildlife opportunities, a reas most suitable for agriculture, and areas necessary for the expansion of municipalities and industries.

\section{FLOODS}

Floods are not considered a current major problem in the county because: (1) The discharge of the Wisconsin River is well regulated with storage reservoirs, (2) surface runoff to the Waupaca and Little Wolf Rivers and to streams draining the sand-plain province is small, and reported high-water marks indicate that flood plains are not extensive, and (3) the northwestern part of the county that is subject to floods is sparsely populated and the flood plains are not generally in use.

Floods may be a future problem if homes, businesses, farms, and roads are developed in areas subject to flooding. Adequate zoning of flood plains will identify the limits of flood stages and will aid in the protection of property and lives. Flood plains might be reserved for uses not affected significantly by flooding. Flood-control structures might be considered in the northwestern part of the county.

\section{RECOMMENDATIONS FOR FUTURE STUDIES}

This report provides estimates of the water resources of the county necessary for initial guidance in developing future water supplies, but much additional data must be obtained before a comprehensive 
plan can be established for the systematic development and management of the total water resources of the area. A continuing inventory of water resources is needed to evaluate the long-term effects of water use upon the hydrologic system and to refine or check the conclusions reached in this investigation, as new data become available. The inventory should be made of ground-water provinces or drainage basins and should not be limited to political areas, such as the county.

In order to determine the discharge from the provinces, it will be necessary to gage streamflow near the mouths of streams draining into the Wisconsin and Waupaca Rivers. Streamflow data are needed also at selected points along the streams to determine gains or losses in the streams and to estimate the long-term effects of water use on stream discharge. Gaging stations should be established also on the Plover River above Sterens Point and at Whiting to determine the effects of industrial and municipal pumping on streamflow.

Information is needed on low flow, flood flow, and the duration of flow of Mill Creek to determine the hydrologic feasibility of dereloping a surface-water reservoir near Junction City. The extent of flood plains needs to be determined.

The network of observation wells should be expanded to determine more accurately the seasonal fluctuations of water levels and to determine the effects of water use on water levels and ground-water storage. Test wells need to be drilled to determine more accurately the thickness of the aquifer, and aquifer tests should be made to refine the estimate of the hydraulic characteristics of the aquifer. Periodic canvasses of newly constructed wells should be made to determine their location and to extend current information on the availability of ground water.

The use of water for all purposes should be appraised and evaluated continually for effective water management.

A detailed study should be made to determine areas of ground-water pollution and the movement of polluted water to points of discharge.

The present information on the occurrence of iron in ground water could be refined by obtaining additional data on the change of iron concentration with depth and areal extent, and on the effects of pumpage and drainage on the amount of iron in solution.

\section{CONCLUSIONS}

The results of the study have shown that, in most parts of Portage County, good water is plentiful, cheap, and taken for granted. Portage County has nearly 9,000 acres of public surface water which includes 104 lakes, about 110 miles of trout streams, and the large flow of the Wisconsin River. Thick and extensive deposits of sand and gravel, sandy till, and alluvium store about 7 million acre-feet of 
water and release annually about 460 efs of water to the streams. With reasonable use and management of these abundant and renewable resources, the county is not likely to have problems of depletion or of general scarcity of water in the foreseeable future.

The hydrologic and geologic characteristics of the sand-plain, drift, and drift-crystalline rock provinces are briefy summarized in figure 20 .

Portage County receives annually about 31 inches of precipitation, of which about 6 inches accumulates on the surface as snow. The average annual loss of water through evapotranspiration is about 21 inches. The average annual rate of evapotranspiration from surfacewater bodies is about 31 inches and from soil moisture and ground water is about 20 inches. The average annual water yield is about 10.6 inches and consists of about 10.3 inches of nunoff to the Wisconsin, Waupaca, and Little Wolf Rivers, about 0.2 inch of water which leaves the county as ground-water underflow, and about 0.1 inch of water which is used consumptively.

Water for industry, irrigation, or other large-scale use is available from wells in the sand-plain and drift provinces of the county. The best areas for development of large ground-water supplies are in sand and gravel deposits in the central and southern parts of the sand-plain province, and in sand and gravel deposits in the Waupaca River valley, the Radley and Murry Creek areas, and the Rosholt area in the drift province. The large and sparsely inhabited southwestern part of the sand-plain province appears to be especially promising for the potential development of large quantities of ground water. The water potential in the vicinty of most of the cities and towns is adequate for the expansion of their public water supplies.

In the northwestern part of the county, however, where water is locally scarce or poor in quality, the problems of developing or maintaining an adequate water supply are of immediate and vital concern. The greatest problem area is Junction City where only a limited supply of poor quality water is available. Additional supplies of water for Junction City possibly can be obtained from shallow sand and gravel deposits that occur in the Mill Creek area, several miles east of the village, or from the Wisconsin River, about 5 miles to the east.

The yield of wells generally increases with the depth of penetration and the length of the screen or gravel pack. In the sand-plain province, a properly constructed well, developed in the sand and gravel aquifer and having about 50 feet of screen or gravel pack, probably would yield 1,500 to $2,000 \mathrm{gpm}$.

In the sand-plain and drift provinces, ground-water runoff is large (about 9 inches a year) and surface runoff is small (about 1 inch a year) and of short duration. In the drift-crystalline rock province, 
however, ground-water runoff is small (about 2 inches a year) and surface runoff is large (about 8 inches a year) and varies greatly in rate of flow.

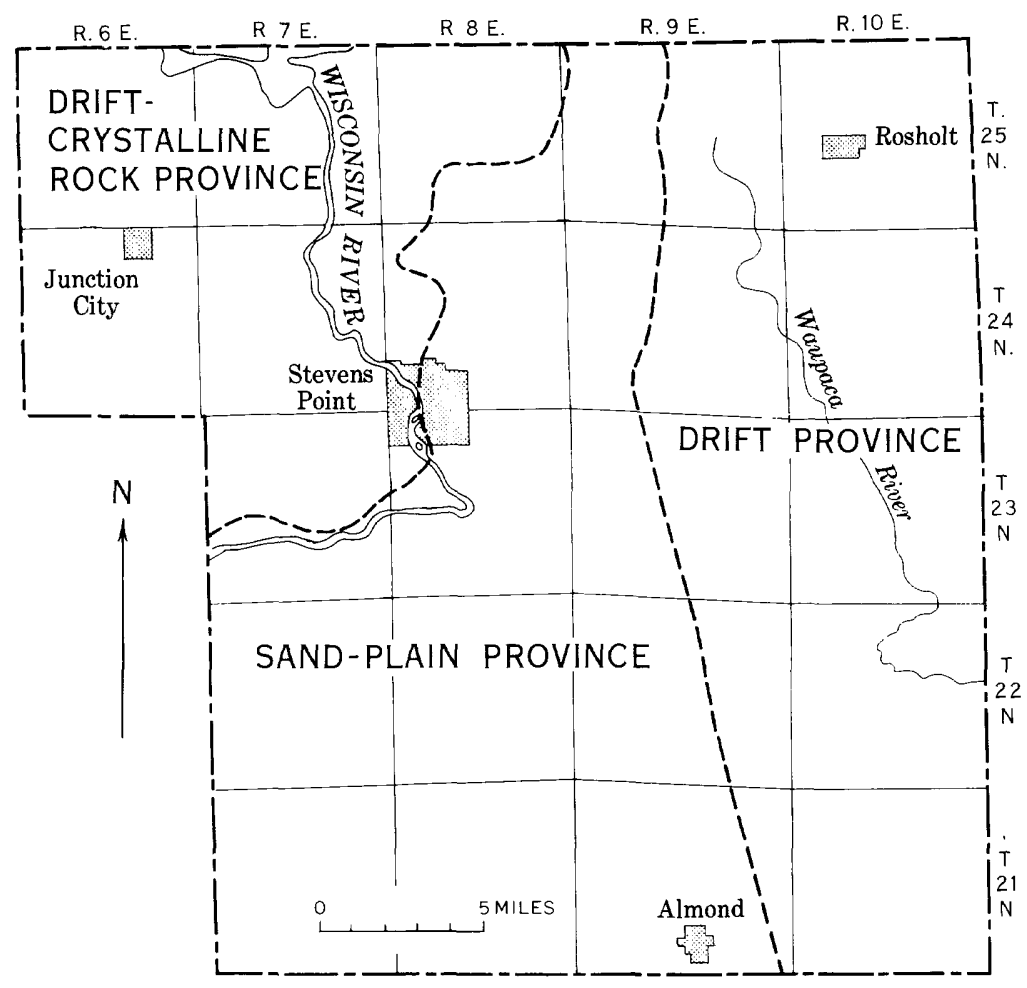

SUMMARY OF HYDROLOGIC CONDITIONS OF PROVINCES

Drift-crystalline rock province.-Thin deposits of clay till, outwash, and alluvium overlying crystalline rock. Only small water supplies developed from outwash. alluvium, and joints in bedrock. Hardness of water ranges from soft to very hard. Iron content may be objectionable locally. Ground-water runoff is small. and surface runoff is large.

Dift province.-Thick deposits of sandy till: glaciofluvial deposits of sand, gravel, silt, and clay; and alluvium and marsh deposits underlain by crystalline rock in the north and sandstone in the south. Adequate domestic water supplies are a vailable almost everywhere. Wells yielding as much as $500 \mathrm{gpm}$ can be developed from thick deposits of sand and gravel.

Chemical quality of water is generally satisfactory although iron content may be objectionable locally. The water ranges from hard to very hard. Groundwater runoff is large, and surface runoff is small and of short duration. Sand-plain province.-Predominantly sand and gravel; some silt and clay. Has large areal extent and average thickness of 100 feet. Underlain by crystalline rock in the north and sandstone in the south. Wells yielding 1,000 gpm can be developed in most of the area. Chemical quality of water is generally satisfactory, although iron content may be objectionable locally. Hardness ranges from soft to very hard. Ground-water runoff is large, and surface runoff is small and of short duration.

FIGURE 20.- Map of Portage County showing ground-water provinces. Base from Wisconsin Highway Commission road map. 
Under current conditions in Portage County, ground-water reservoirs are full to overflowing. Streamflow and springs are sustained by the almost constant discharge of ground water. Wetlands and the stages of lakes and ponds are maintained by a water table that fluctuates seasonally only a few feet. The pumping of high-capacity irrigation wells has not materially depleted the flow of streams or lowered the stages of lakes, because the wells are widely spaced, pumped less than 3 months per year, and the annual average pumpage is considerably less than the average annual recharge. To prevent excessive declines in water levels because of interference between wells pumping about $1,000 \mathrm{gpm}$, the wells should be spaced about 2,500 feet apart. So long as the high-capacity wells are spaced adequately and the average annual pumpage is less than the average anmual recharge, there will be no significant declines in regional water levels. In the Stevens Point area, heavy pumping from industrial and municipal wells induces recharge from the Plover River.

Water is used for many purposes in the county-to sustain plant and animal life, to generate power, in manufacture of goods, and for cooling. In 1960, about $12.8 \mathrm{mgd}$ of ground water was withdrawn from wells and pits, of which about 48 percent was used by self-supplied industry, about 30 percent for irrigation, about 16 percent for public supply, and about 6 percent for domestic and stock purposes. About onethird of all ground water withdrawn was used consumptively. The withdrawal of surface water in 1960 was about $0.3 \mathrm{mgd}$, excluding the water used for generation of electric power.

The chemical quality of ground water is generally good, but hard water and undesirable amounts of iron create local treatment problems. The water of best chemical quality occurs in the outwash sand and gravel near the Wisconsin River. Hard to very hard water is common to the glacial drift in the eastern part of the county and is also found in several areas in the outwash plain. Objectionable quantities of iron are present in many areas of the county, and the greatest concentration is in the central part of the outwash plain. Most of the areas having iron problems are in swamps and marshes or areas where the movement of ground water is very slow.

Pollution of ground water is a present and potential problem in the Amherst, Bancroft, Junction City, Plover, Rosholt, Stevens Point, and Whiting areas where housing is concentrated, the water table is near the surface, and pollutants may move readily into the aquifer. Several methods have been suggested for correcting the pollution problem. 


\section{SELECTED REFERENCES}

Audini, R. E., Berkstresser, C. F., and Knowles, D. B., 1959, Water levels in observation wells in Wisconsin through 1957: Wisconsin Geol. and Nat. History Survey Inf. Circ. 4, 192 p.

Bean, E. F., 1949, Geologic map of Wisconsin: Wisconsin Geol. and Nat. History Survey.

Butler, S. S., 1957, Engineerinng Hydrology: Englewood Cliffs, New Jersey, Prentice-Hall, p. 73.

Chamberlin, T. C., 1877. Geoogy of eastern Wisconsin, in Geology of Wisconsin : Wisconsin Geol. and Nat. History Survey, v. 2, pt. 2, p. 93-405.

-1882, Superficial geology of the upper Wisconsin valley, in Geology of Wisconsin: Wisconsin Geol. and Nat. History Survey, v. 4, pt. 8, p. 715-723. 1883, General geology, in Geology of Wisconsin: Wisconsin Geol. and Nat. History Survey, v. 1, pt. 1, p. 3-300.

Drescher, W. J., 1956, Ground water in Wisconsin: Wisconsin Geol. and Nat. History Survey Inf. Circ. 3, 36 p.

Ferris, J. G., Knowles, D. B., Brown, R. H., and Stallman, R. W., 1962, Theory of aquifer tests: C.S. Geol. Survey Water-Supply Paper 1536-E, p. 69-174.

Hem, John D., 1959, Study and interpretation of the chemical characteristics of natural water: U.S. Geol. Survey Water-Supply Paper 1473, p. 58-66.

Hole, F. D., 1943, Correlation of the glacial Border drift of north central Wisconsin : Am. Jour. Sci. v. 241, p. 498-516.

Holt, C. L. R., Jr., 1956, Ground water in Pleistocene sediments in central Wisconsin [abs.] : Geol. Soc. America Program, 1956, Ann. Mtg. p. 60.

Kirchoffer, W. G., 1905, The sources of water supply in Wisconsin: Wisconsin Univ. Bull. 106, eng. ser., v. 3, no. 2, p. 163-249.

Leopold, Aldo, 1949, A sand county almanac and sketches here and there: New York, Oxford Univ. Press, p. 99-101.

Leverett, Frank, 1929, Moraines and shore lines of the Lake Superior basin: U.S. Geol. Survey Prof. Paper 154-A, p. 29-31.

1932, Quaternary geology of Minnesota and parts of adjacent States: U.S. Geol. Survey Prof. Paper 161, p. 22-23.

Martin, Lawrence, 1932, The physical geography of Wisconsin: Wisconsin Geol. and Nat. History Survey Bull. 36, 608 p.

MacKichan, K. A., and Kammerer, J. C., 1961, Estimated use of water in the

United States, 1960 : U.S. Geol. Survey Circ. 456, 44 p.

Meinzer, O. E., 1923, The occurrence of ground water in the United States, with a discussion of principles: U.S. Geol. Survey Water-Supply Paper 489, p. 22.

Palmer, W. C., and Havens, A. V., 1958, A graphical technique for determining evapotranspiration by the Thornthwaite method: U.S. Weather Bureau Monthly Weather Rev., April 1958, p. 123-128.

Rasmussen, W. C., and Andreasen, G. E., 1959, Hydrologic budget of the Beaverdam Creek basin, Maryland: U.S. Geol. Survey Water-Supply Paper 1472, p. 82-83.

Stallman, R. W., 1961, Boulton's integral for pumping-test analysis: U.S. Geol. Survey Prof. Paper 424-C, art. 155, p. 24-29.

Theis, C. V., 1935, The relation between the lowering of the peizometric surface and the rate and duration of discharge of a well using ground-water storage: Am. Geophys. Union Trans., pt. 2, p. 519-524. 
Thwaites, F. T., 1940, Buried pre-Cambrian of Wisconsin: Wisconsin Acad. Sci., Arts and Letters Trans., v. 32, p. 233-242.

1943, Pleistocene of part of northeastern Wisconsin: Geol. Soc. America Bull., v. 54, p. 119-120.

-1946, Outline of glacial geology : Ann Arbor, Mich., Edwards Bros., Inc., p. 78-80 [1953].

U.S. Department of Commerce, 1960, 1960 Census of population, Wisconsin : U.S. Dept. Commerce Bur. Census Advance Rept., PC(A1)-51, 19 p.

U.S. Geological Survey, 1962, Surface-water records of Wisconsin, 1961: U.S. Geol. Survey open-file report, $143 \mathrm{p}$.

U.S. Public Health Service, 1962, Drinking water standards, 1962 : U.S. Public Health Service Pub. 956, 61 p.

U.S. Weather Bureau, 1961, Climatological data, Wisconsin, 1960 : U.S. Dept. Commerce, Ann. Summary, v. 65, n. 13, p. 200-201.

Weidman, Samuel, 1907, The geology of north-central Wisconsin: Wisconsin Geol. and Nat. History Survey Bull. 16, p. 447-450.

Weidman, SamueI, and Schultz, A. R., 1915, The underground and surface water supplies of Wisconsin: Wisconsin Geol. and Nat. History Survey Bull. $35,664 \mathrm{p}$.

Whitson, A. R., Geib, W. J., Dunnewald, T. J., and Hanson, L. P., 1918, SoiI survey of Portage County, Wisconsin: Wisconsin Geol. and Nat. History Survey Bull. $52 \mathrm{C}, 79 \mathrm{p}$.

Wirth, H. E., 1959, Water use in Wisconsin: Wisconsin State Board of Health, $36 \mathrm{p}$.

Wisconsin Bureau of Sanitary Engineering, 1935, Public water supplies of Wisconsin : Wisconsin State Board of Health, $31 \mathrm{p}$.

Wisconsin Conservation Department, 1954, Forest resources of Portage County, Wisconsin: Wisconsin Conserv. Dept. Forest Inventory Pub. 3, 22 p.

Wisconsin Conservation Department, 1958, Wisconsin lakes : Wisconsin Conserv. Dept. Pub. 218-58, 35 p.

Wisconsin Department of Agriculture, 1953, Portage County agriculture, Wisconsin: Wisconsin Dept. Agriculture Crop Reporting Service Bull., p. 6.

1960, Wisconsin Iivestock and poultry, 1960: Wisconsin Dept. Agriculture Annual Livestock Summary, $18 \mathrm{p}$.

Wisconsin Department of Resource Development, 1961 Economic profile, Portage County, Wisconsin : Wisconsin Dept. Resource Devel. Pub., 6 p.

Wisconsin State Board of Health, 1962, Public water works and sewerage systems in Wisconsin : Wisconsin State Board of HeaIth, $20 \mathrm{p}$. 


\section{INDEX}

\section{[Italic page numbers indicate major references]}

A

Acknowledgments.........................

Alluvium

Amherst, water supply

Aquifer, defined.

characteristics, pumping test determinations

Arnott moraine.

Page

Arnott plain

Artesian aquifer, defined

\section{B}

Bancroft

Bancroft plain

Bear Creek

valley.......-.

ig Eau Pleine River, discharge

gaging station.

runoff

Big Eau Pleine River basin

Border Drift of Hole (1943)................... 24, 26

Boulton's integral equation

Buena Vista Creek.

\section{C}

Cary drift

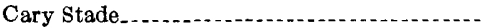

Central sand plain.

Chemical quality, water.

Climate.

Coefficient of permeability, defined.

Coefficient of storage, data defined

Coefficient of transmissibility, data......... $\$ 6,42$ defined.

Cone of depression, defined

Conflict of interests.

Continental glaciers

Crystalline rocks, water-yielding character...

D

Discharge, Big Eau Pleine River general.

Little Plover River...............................

Waupaca River basin.

Wisconsin River

Ditches, drainage

Domestic water use.

Downwastage.

Drainage basins.

Drainage ditches, average runoff

Drainage outlets
Dresbach Group

rift-crystalline rock province, ground-water runoff-

ground-water use-s-0-0-

recharge

water resources............................. $s 9$

water supply

Drift province, ground-water runoff.......... $\quad 52$

ground-water use........................ 61

specific capacity of wells.................. 39

water resources.............................. $\quad 3 s$

Drought (1956-59), effect on water levels..... $\quad 47$

Du Bay reservoir............................... 17

Dune sand . ...................................... 31

$\mathbf{E}$

Elderon morainic system

Evapotranspiration......................... 7,9,54

\section{F}

Field capacity, data

defined. 34

Field coefficient of permeability, data........ 36

Field-moisture capacity .................... 10

Field specific capacity, data................ $\quad 35$

Field specific yield, defined.................... $\quad 37$ sand-plain province......................... 53

Flood plains, zoning.......................... 68

Floods

Fourmile Creek ................................ 15

Future studies............................. 68

\section{G}

Glacial drainage........... 28

Glacial drift................................... 24

Glacial Lake Oshkosh...................... 28

24 Glacial Lake Wisconsin..................... 28

21 Green Bay lobe, Wisconsin ice sheet. . . ...... 24, 27

Ground water, consumption............... 54 divides........................... 13, 14, 32,41

estimated discharge....................... 53

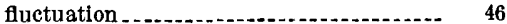

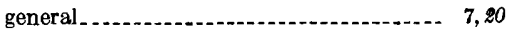

hydrographs . . .

irrigation use................................ 64

movement velocity

pctential development. . ................ 33

provinces..................................... $\$ 1$

relation to surface water.................... 12

reservoirs 43

storage $\ldots \ldots \ldots \ldots$

total withdrawn............................ 61

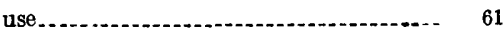


Hardness.

Hay Meadow Creek.

History of area

Hydraulic gradient

Hydrologic boundaries

Hydrologic system.

\section{I}

Ice-contact deposits

Ice-fracture fillings

Industry, water use

Iron content of water

Irrigated land.

Irrigation, water use.

Irrigation wells, effect on water level.

J

Junction City, iron content of water. water supply

K

Kame deltas.

Kame terraces

Kames

Kettles, defined

\section{$\mathbf{L}$}

Laboratory specific yield

Lakes.

Land-locked lakes, decline in stage . . . ....... Land use

Leopold, Aldo, quoted.

Little Eau Pleine River

Little Plover River, discharge

gaging station

runoff.

Little Plover River basin, average annual discharge

Little Wolf River, runoff.

Little Wolf River basin

Location and development

Lumbering

\section{M}

Manufacturing

Marsh deposits

Mill Creek

Moraine deposits

Moraines

(1)

Movement, ground-water

$\mathrm{N}$

Nonequilibrium equation

Observation wells, network

Outer moraine.

Outwash.

Paper manufacturing
Pits, water source.

Page

Plover.

Plover River, gaging station._............... 15

induced recharge ........................ 50

Plover River basin, average discharge...... $\quad 15$

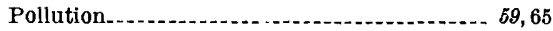

Wisconsin River......................... 66

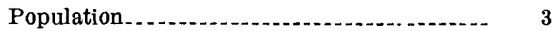

Porosity, data

defined..................................... 34

Postglacial deposits .......................... $\$ 1$

Potential evapotranspiration.............. $\quad 10$

Potential specific yield, defined.............. $\quad 35$

Precipitation, affect on water level. .......... $\quad 46$ annual............................ 4

Previous reports................... 4

Public water supply

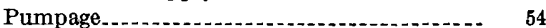

Pumping tests . . .

Purpose............. 2

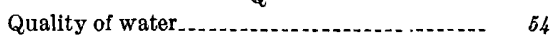

R

Recharge, general $\ldots$

induced .............. 50

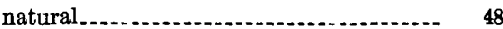

precipitation .............................. 35

Recreation - ....-..- 65

Relief, crystalline rock. . ................... 22

Rocky Run Creek . ......... 17

Rosholt..................................... 66

Runoff, Big Eau Pleine River............... 52

Little Wolf River........................ 19

overland . ................................. 12

Wisconsin River basin.................... 18

\section{S}

Sample log ................ 30

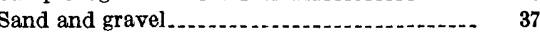

Sand-plain area _. ........................... 15, 17

Sand-plain province, ground-water runoff . ..- $\quad 52$

ground-water storage..................... 53

ground-water use.......................... 61

iron content of water ..................... 58

pumpage................................. 54

recharge

specific capacities of wells . . _._._._._._._. $\quad 39$

underflow ................................ 54

water resources............................. 92

Sandstone, water-yielding character .......... 23 mounds . . . . . . . . . 23,29

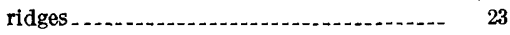

Second moraine . ...................... 13, 27, 28

Sewage-treatinent system. . .

36 Snowfall _ . . _..._._.

Sodium content ............................. 59

Soil meisture

capacity, defined....................... 34

deficiency . . _

Soil water, evapotranspiration............... 9

Source of water

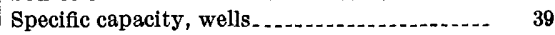

Specific retention, defined ..................... 34

Specific yield, data

defined..................................... 34 
Stevens Point, iron content of water

pollution.

pumping test.

reservoir

use of water.

water supply

well field.

Stock, water use

Streamflow data, need.

Surface water, amount

evapotranspiration

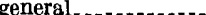

irrigation use.

principal industrial use

relation to ground water.

use.

\section{$\mathbf{T}$}

Temperature, air

ground water

Tenmile Creek.

Terraces...............

Thwaites, F. T., quoted

Till. water source.

Topographic divides

Trout streams.

U

Underfiow

V

Valley alluvium

\begin{tabular}{|c|c|c|}
\hline Page & W & Page \\
\hline 59 & Water, budget_........... & $\gamma$ \\
\hline 66 & law, ground water.... & 65 \\
\hline 50 & level, effects of pumping & 37 \\
\hline 17 & excessive declines. & 67 \\
\hline 68 & fluctuations... & 43 \\
\hline 63 & loss. & 10 \\
\hline 50 & management problems. & 65 \\
\hline 63 & power & 62 \\
\hline 69 & problems. & 67,68 \\
\hline 69 & resources, inventory & 69 \\
\hline 9 & table, gradient........ & 42 \\
\hline 13 & shape and slope.... & 41 \\
\hline 64 & conditions, defined. & 20 \\
\hline 62 & contours & 41 \\
\hline 12 & use & 61 \\
\hline 61 & yield, average annual & 7 \\
\hline & defined.......... & 7 \\
\hline & Waupaca River, ground-water runoff...-.....- & 52 \\
\hline $\begin{array}{r}4 \\
59\end{array}$ & induced recharge... & 50 \\
\hline 59 & Waupacs River basin.. & 18 \\
\hline 28 & Wells, construction..... & 36 \\
\hline 25 & numbering system... & 5 \\
\hline 24 & spacing-....--- & 38,67 \\
\hline 26 & yield...... & 33 \\
\hline 13,15 & Wetlands............... & 4,19 \\
\hline 4 & Whiting & 66 \\
\hline \multirow{4}{*}{48,53} & Wildlife & 65 \\
\hline & Wisconsin Glaciation & 24 \\
\hline & Wisconsin River, discharge & 7,18 \\
\hline & Wisconsin River basin & 15 \\
\hline & Wisconsin Statute 30.18, water law & 65 \\
\hline
\end{tabular}

0 